\title{
\#USGS
}

Prepared in cooperation with the Confederated Tribes of the Umatilla Indian Reservation,

Department of Natural Resources, and Northwest Marine Fisheries Service

\section{Physical Habitat Monitoring Strategy (PHAMS) for Reach-Scale Restoration Effectiveness Monitoring}

*.

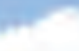

ath

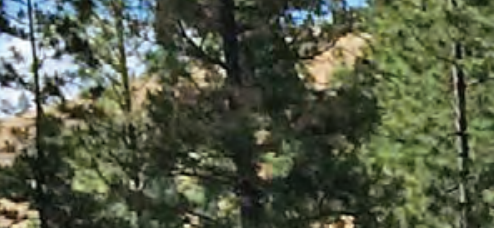
(2) 20

.

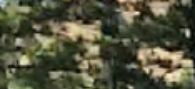

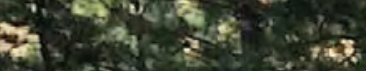

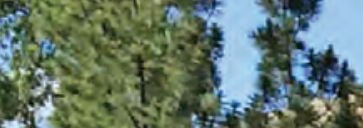

$\frac{6}{6}$

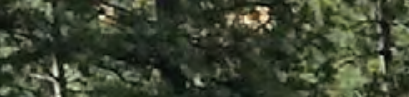

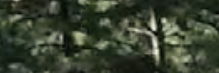

i.
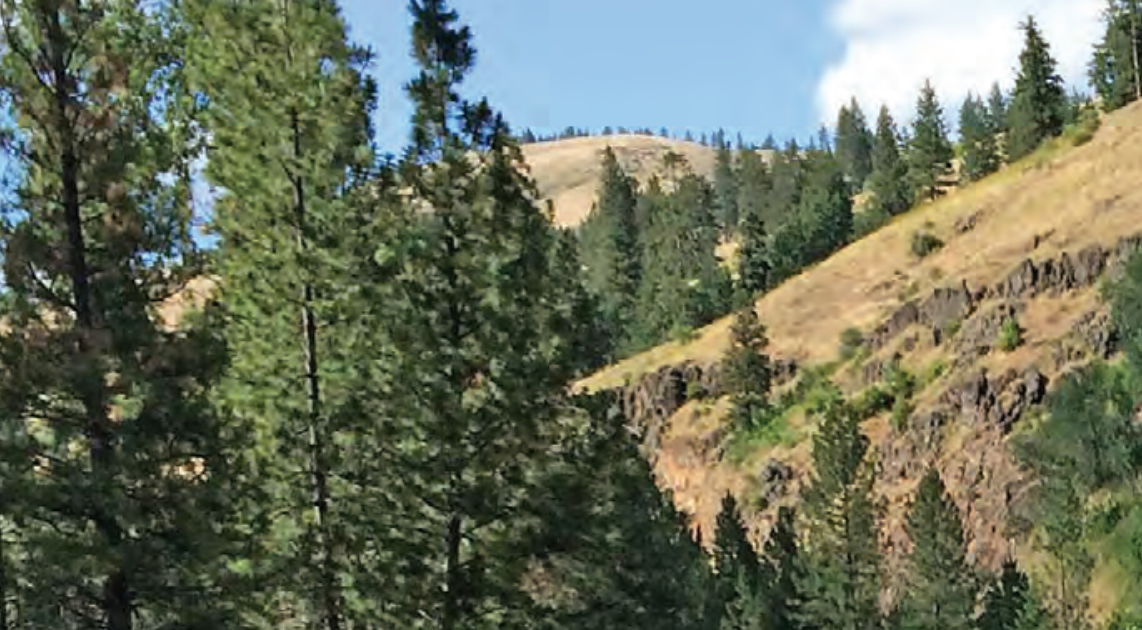

애을
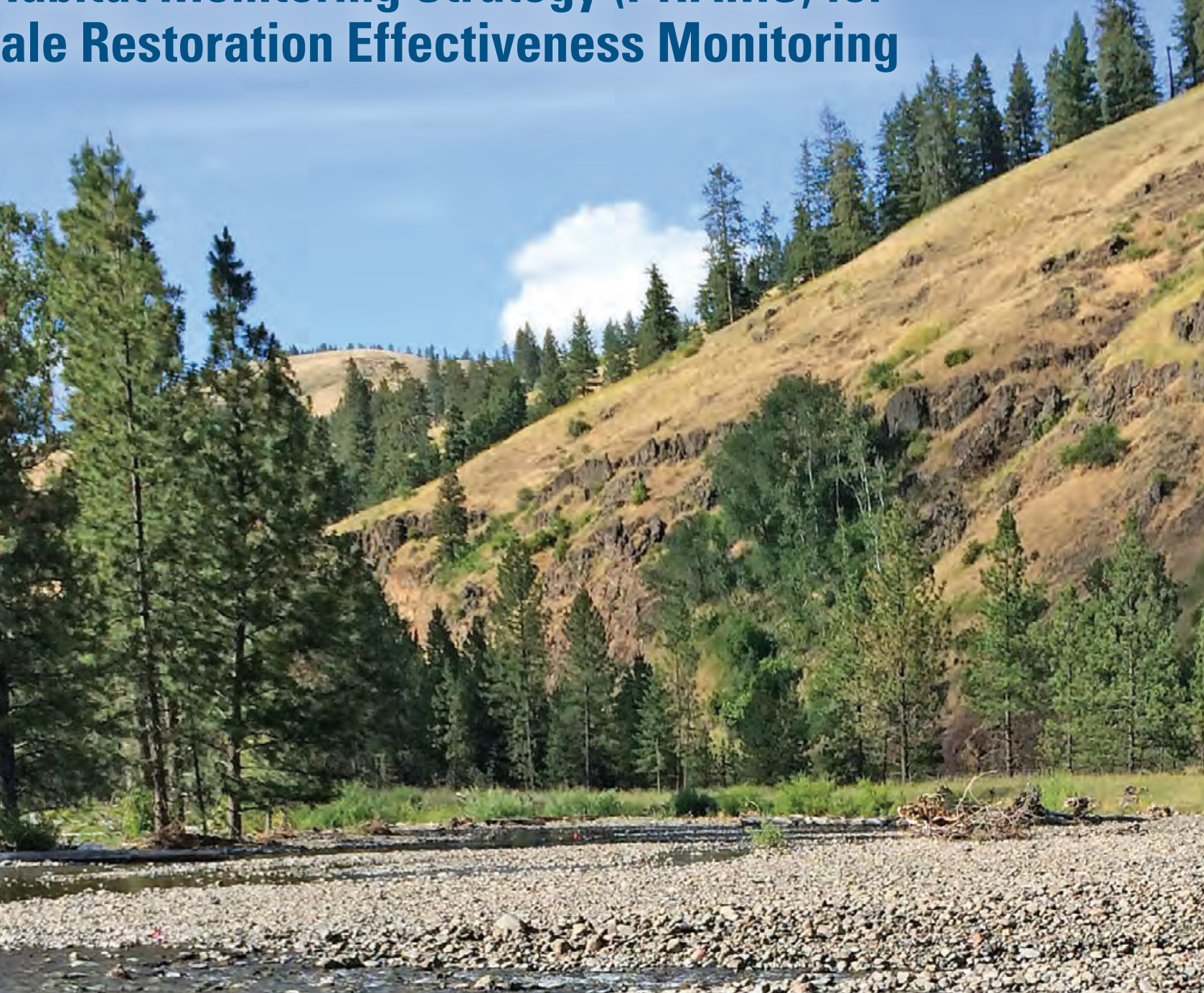

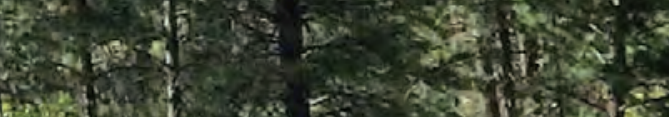

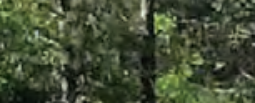

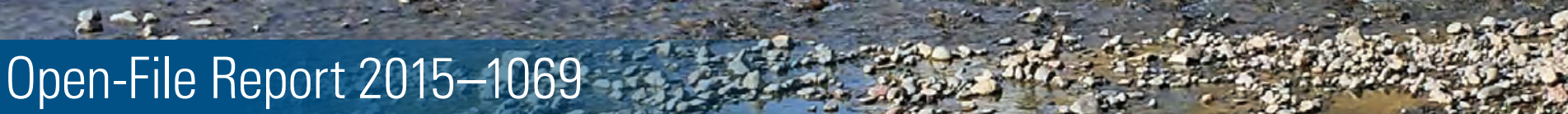

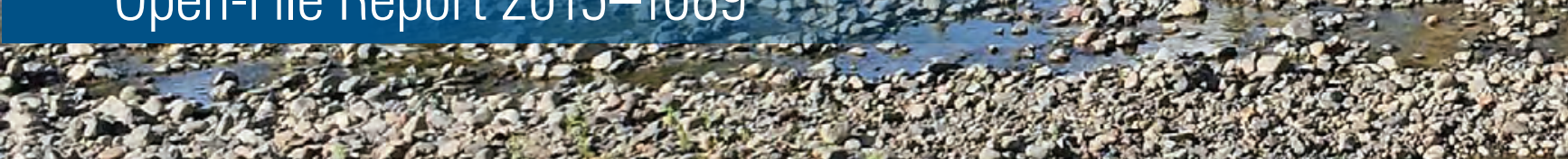

(2)

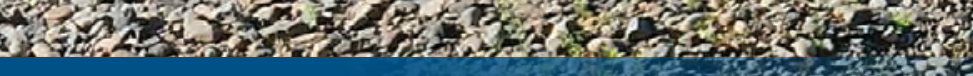

U.S. Department of the Interior

U.S. Geological Survey 
Cover: Photograph taken at Meacham Creek, Oregon, by Krista Jones, U.S. Geological Survey, June 2014. 


\section{Physical Habitat Monitoring Strategy (PHAMS) for Reach-Scale Restoration Effectiveness Monitoring}

By Krista L. Jones, Scott J. O'Daniel, Tim J. Beechie, John Zakrajsek, and Jim G. Webster

Prepared in cooperation with the Confederated Tribes of the Umatilla Indian Reservation, Department of Natural Resources, and Northwest Marine Fisheries Service

Open-File Report 2015-1069

U.S. Department of the Interior

U.S. Geological Survey 


\section{U.S. Department of the Interior SALLY JEWELL, Secretary}

\section{U.S. Geological Survey \\ Suzette M. Kimball, Acting Director}

U.S. Geological Survey, Reston, Virginia: 2015

For more information on the USGS—-the Federal source for science about the Earth, its natural and living resources, natural hazards, and the environment-visit http://www.usgs.gov or call 1-888-ASK-USGS (1-888-275-8747)

For an overview of USGS information products, including maps, imagery, and publications, visit http://www.usgs.gov/pubprod

Any use of trade, firm, or product names is for descriptive purposes only and does not imply endorsement by the U.S. Government.

Although this information product, for the most part, is in the public domain, it also may contain copyrighted materials as noted in the text. Permission to reproduce copyrighted items must be secured from the copyright owner.

Suggested citation:

Jones, K.L., O'Daniel, S.J., Beechie, T.J., Zakrajsek, John, and Webster, J.G., 2015, Physical habitat monitoring strategy (PHAMS) for reach-scale restoration effectiveness monitoring: U.S. Geological Survey Open-File Report 2015-1069, 58 p., http://dx.doi.org/10.3133/ofr20151069.

ISSN 2331-1258 (online) 


\section{Contents}

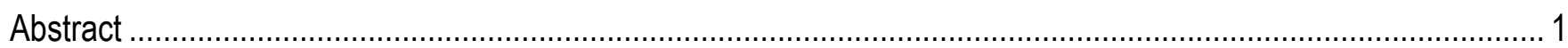

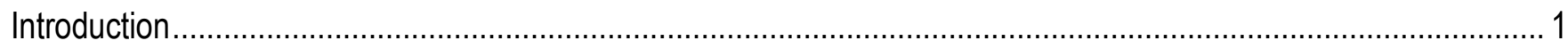

Organizing Principles of the Physical Habitat Monitoring Strategy ................................................................. 4

The River Vision is the Conceptual Framework for Restoration Efforts by Confederated Tribes of the

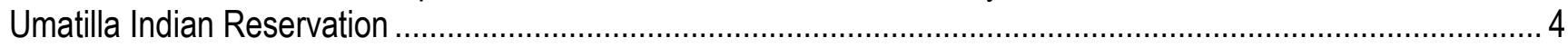

Processes at Different Spatial and Temporal Scales Control Physical Habitat ..................................................

Scale is an Important Consideration for Selecting Monitoring Parameters ......................................................

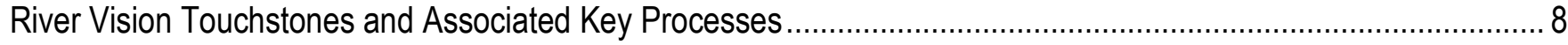

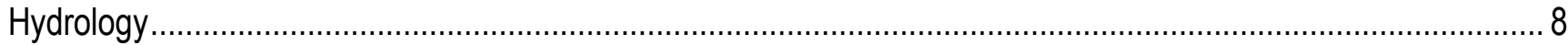

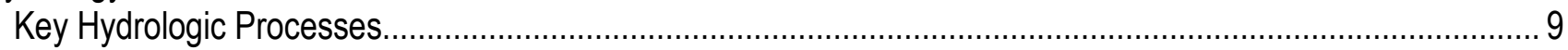

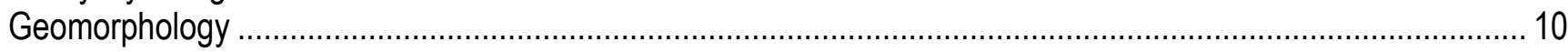

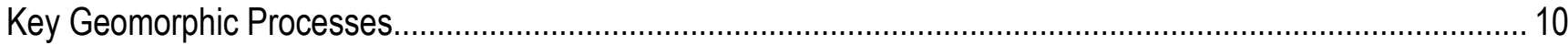

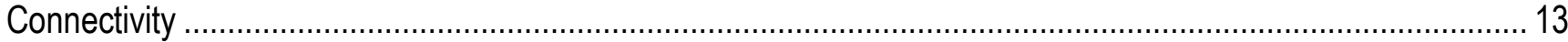

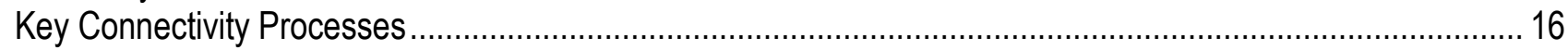

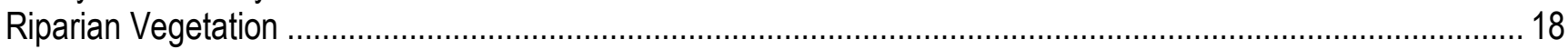

Key Riparian Vegetation Processes ................................................................................................ 18

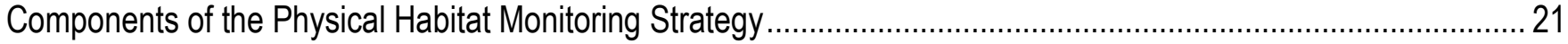

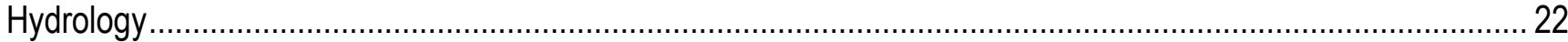

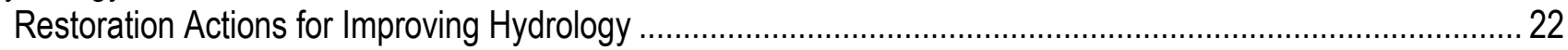

Hydrologic Monitoring Parameters and Techniques ................................................................................ 24

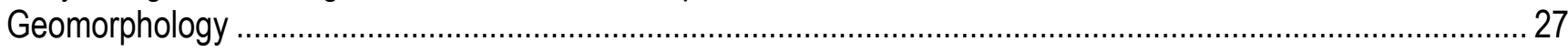

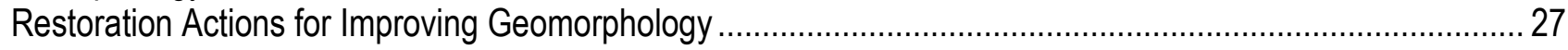

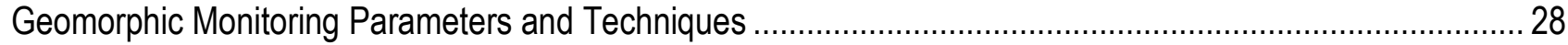

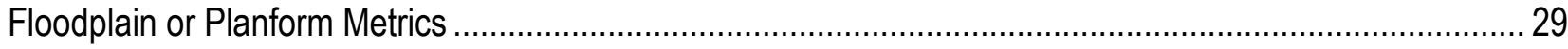

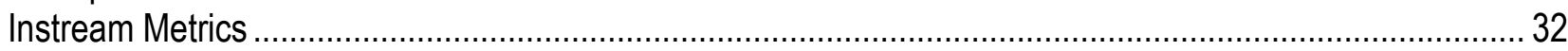

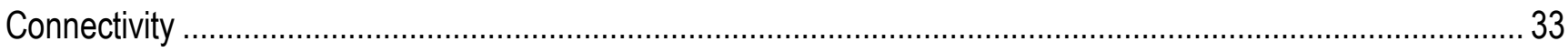

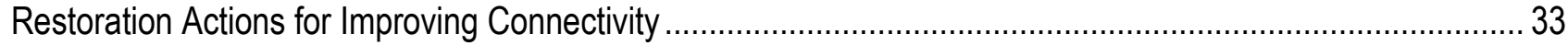

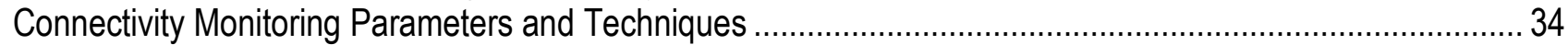

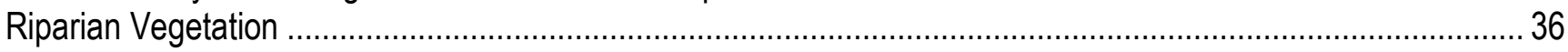

Restoration Actions for Improving Native Riparian Vegetation .................................................................36

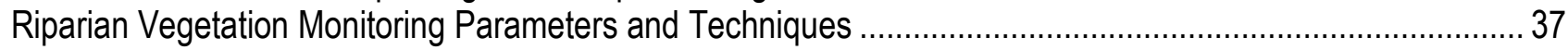

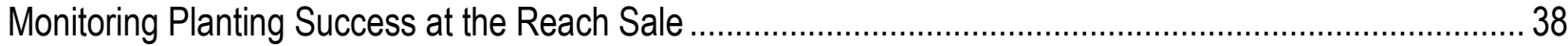

Example of the Need for Complementary Monitoring Approaches ..................................................................... 40

Limiting Factors and Restoration Actions at the Meacham Project ................................................................. 40

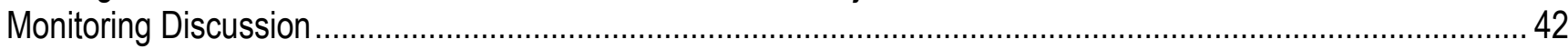

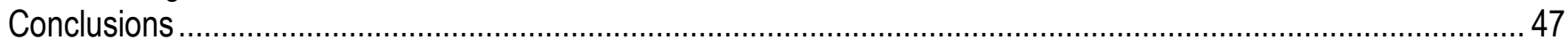

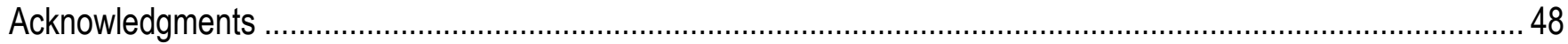

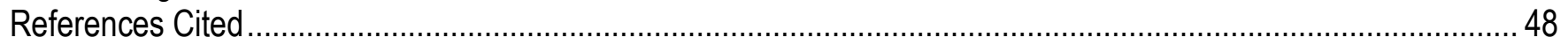




\section{Figures}

Figure 1. Map showing aboriginal title lands of the Umatilla, Cayuse, and Walla Walla Tribes of the Confederated Tribes of the Umatilla Indian Reservation

Figure 2. Illustration of the hierarchy of controls on river morphology and habitat, including $(A)$ reach-scale processes, $(B)$ watershed-scale processes, and $(C)$ the landscape template......

Figure 3. Cross-section of a hypothetical functional floodplain showing a range of channels ..................... 9

Figure 4. Conceptual diagram showing erosion processes including soil creek, surface erosion, and mass wasting (or land sliding)

Figure 5. Graph showing balance between sediment supply and transport capacity, showing that reaches receiving more sediment than they can transport will aggrade, and reaches that can transport more sediment than they receive will incise or become armored.

Figure 6. Characterization showing the River Continuum Concept......................................................... 14

Figure 7. Characterization showing flood pulses and floodplain inundation with progressively increasing stream discharge events indicated by lighter coloring .....

Figure 8. Unhealthy meadow with reduced natural storage of water, lowered groundwater table, flood flows confined to channel with no inundation during floods, and xeric (or dry) vegetation.........................20

Figure 9. Graphs showing potential influences of hyporheic flow on instream temperatures .....................26 Figure 10. Maps showing observed and predicted zones of cooling and hyporheic potential based in the Umatilla River, Oregon

Figure 11. Isometric flow paths through the alluvial floodplain of Meacham Creek, Oregon. Isolines were generated using the MODTRACE module of MODFLOW

\section{Tables}

Table 1. Restoration actions used by the Confederated Tribes of the Umatilla Indian Reservation to address hydrology objectives

Table 2. Restoration objectives, metrics, methods, and references for restoration projects addressing

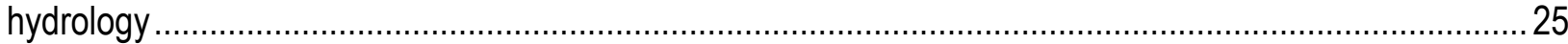

Table 3. Restoration actions used by the Confederated Tribes of the Umatilla Indian Reservation to address geomorphic objectives

Table 4. Geomorphology monitoring metrics and methods associated with geomorphology restoration objectives.

Table 5. Connectivity monitoring metrics and methods associated with connectivity restoration objectives.

Table 6. Restoration objectives, metrics, methods, and references associated with riparian vegetation restoration objectives.

Table 7. Limiting factors and restoration actions for the Meacham Creek restoration project, Umatilla River Basin, Oregon

Table 8. Locations, restoration years, and project descriptions for the Meacham Creek restoration project, Umatilla River Basin, Oregon ......

Table 9. Instream metrics and methods for the Meacham Creek effectiveness monitoring ....................... 44

Table 10. Riparian and floodplain metrics and methods for the Meacham Creek effectiveness monitoring.....

Table 11. Sediment metrics and methods for the Meacham Creek effectiveness monitoring 46

Table 12. Stream temperature metrics and methods for the Meacham Creek effectiveness monitoring..... 47 


\section{Conversion Factors}

International System of Units to Inch/Pound

\begin{tabular}{lcll}
\hline & Multiply & & To obtain \\
\hline & Length & \\
\hline centimeter $(\mathrm{cm})$ & 0.3937 & inch $(\mathrm{in})$. \\
millimeter $(\mathrm{mm})$ & 0.03937 & inch (in.) \\
meter $(\mathrm{m})$ & 3.281 & foot $(\mathrm{ft})$ \\
kilometer $(\mathrm{km})$ & 0.6214 & mile (mi) \\
kilometer $(\mathrm{km})$ & 0.5400 & mile, nautical $(\mathrm{nmi})$ \\
meter $(\mathrm{m})$ & 1.094 & yard $(\mathrm{yd})$ \\
\hline & Area & \\
\hline square meter $\left(\mathrm{m}^{2}\right)$ & 0.0002471 & acre \\
square meter $\left(\mathrm{m}^{2}\right)$ & 10.76 & square foot $\left(\mathrm{ft}^{2}\right)$ \\
\hline & Flow Rate & \\
\hline cubic meter per second $\left(\mathrm{m}^{3} / \mathrm{s}\right)$ & 35.31 & cubic foot per second $\left(\mathrm{ft}^{3} / \mathrm{s}\right)$ \\
\hline millimeter per year $(\mathrm{mm} / \mathrm{yr})$ & 0.03937 & inch per year $(\mathrm{in} / \mathrm{yr})$ \\
\hline
\end{tabular}

Temperature in degrees Celsius $\left({ }^{\circ} \mathrm{C}\right)$ may be converted to degrees Fahrenheit $\left({ }^{\circ} \mathrm{F}\right)$ as

$$
{ }^{\circ} \mathrm{F}=\left(1.8 \times{ }^{\circ} \mathrm{C}\right)+32 .
$$

\section{Datums}

Vertical coordinate information is referenced to the North American Vertical Datum of 1988 (NAVD 88).

Horizontal coordinate information is referenced to the North American Datum of 1983 (NAD 83).

Altitude, as used in this report, refers to distance above the vertical datum. 
This page left intentionally blank 


\title{
Physical Habitat Monitoring Strategy (PHAMS) for Reach-Scale Restoration Effectiveness Monitoring
}

By Krista L. Jones', Scott J. O'Daniel2, Tim J. Beechie ${ }^{3}$, John Zakrajsek², and Jim G. Webster ${ }^{4}$

\begin{abstract}
Habitat restoration efforts by the Confederated Tribes of the Umatilla Indian Reservation (CTUIR) have shifted from the site scale (1-10 meters) to the reach scale (100-1,000 meters). This shift was in response to the growing scientific emphasis on process-based restoration and to support the 2007 Accords Agreement with the Bonneville Power Administration. With the increased size of restoration projects, the CTUIR and other agencies are in need of applicable monitoring methods for assessing large-scale changes in river and floodplain habitats following restoration. The goal of the Physical Habitat Monitoring Strategy is to outline methods that are useful for capturing reach-scale changes in surface and groundwater hydrology, geomorphology, hydrologic connectivity, and riparian vegetation at restoration projects. The Physical Habitat Monitoring Strategy aims to avoid duplication with existing regional effectiveness monitoring protocols by identifying complimentary reach-scale metrics and methods that may improve the ability of CTUIR and others to detect instream and riparian changes at large restoration projects.
\end{abstract}

\section{Introduction}

The Fisheries Habitat Program of the Confederated Tribes of the Umatilla Indian Reservation (CTUIR) works to restore habitats supporting imperiled anadromous fish populations in the aboriginal title lands of the Cayuse, Walla Walla, and Umatilla Tribes (fig. 1). The Umatilla, Walla Walla, Tucannon, Grand Ronde, and John Day Rivers, as well as parts of the Powder, Burnt, and Malheur Rivers run through the CTUIR's ancestral lands. These rivers are predominately in semi-arid basins with snowmelt driven streamflow regimes and diverse landscapes, including alluvial floodplains, steep headwater streams, meadows, canyons, sagebrush steppes, and conifer and deciduous forests.

\footnotetext{
${ }^{1}$ U.S. Geological Survey.

${ }^{2}$ Confederated Tribes of the Umatilla Indian Reservation, Department of Natural Resources.

${ }^{3}$ Northwest Fisheries Science Center.

${ }^{4}$ Confederated Tribes of the Umatilla Indian Reservation, Department of Natural Resources, and GeoEngineers.
} 


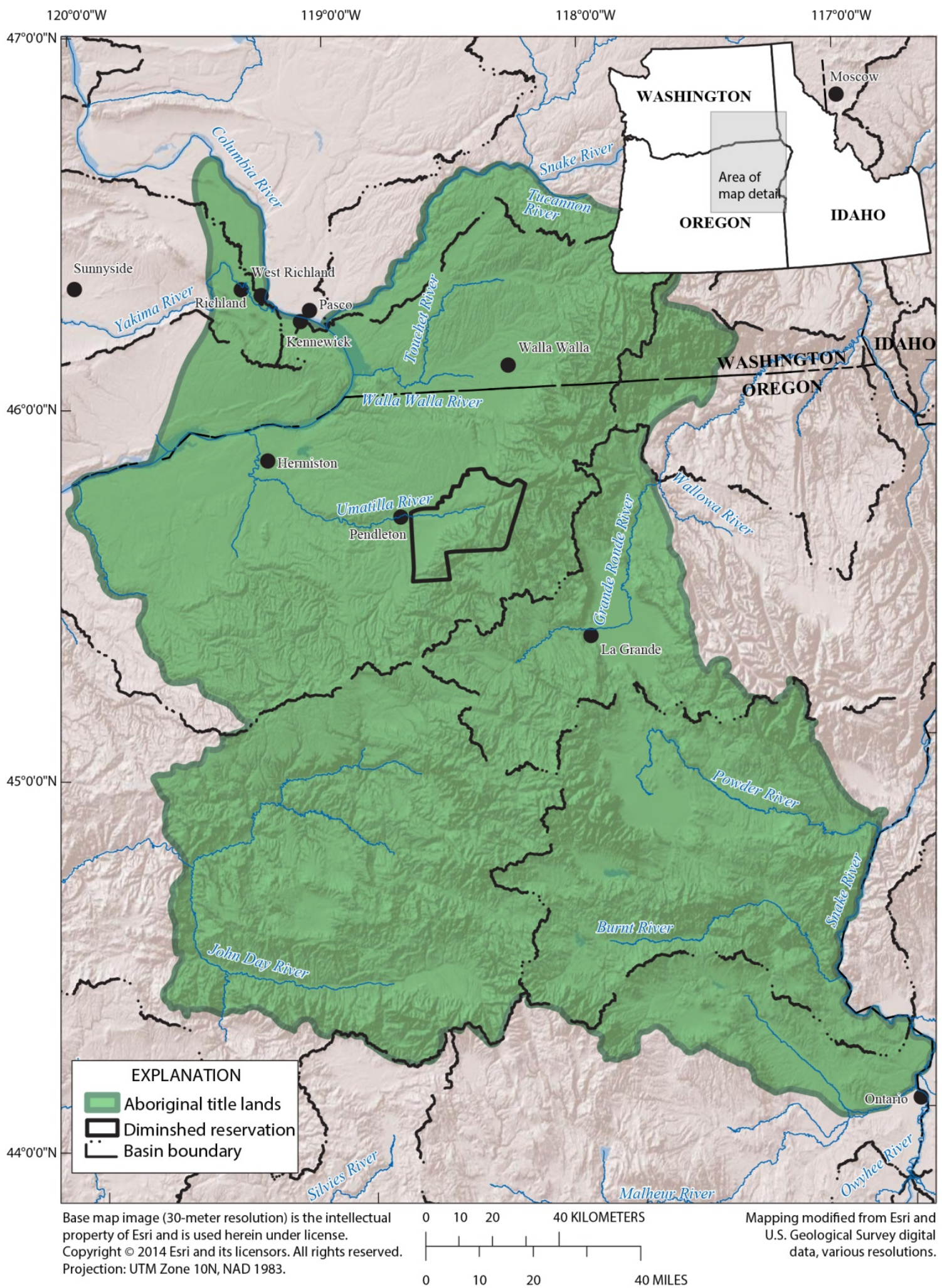

Figure 1. Map showing aboriginal title lands of the Umatilla, Cayuse, and Walla Walla Tribes of the Confederated Tribes of the Umatilla Indian Reservation. 
The CTUIR's Fisheries Habitat Program originally implemented site-scale actions (generally less than 10-100 m long), such as bank stabilization or wood placement, to mitigate the symptoms of habitat degradation. As of 2015, the program largely focuses on the protection, enhancement, and restoration of floodplain and channel processes at the reach scale (100 to more than $1,000 \mathrm{~m}$ long) in order to affect much larger habitat improvements. This shift was motivated by the growing recognition that restoration toward a fixed endpoint only addresses symptoms of habitat degradation, whereas the restoration of process is more likely to address the causes of river ecosystem degradation (Kondolf and others, 2006; Beechie and others, 2010). Building on this concept, present-day restoration efforts seek to recreate historical, or relatively normative, physical processes at a spatial scale large enough to create a range of floodplain habitats, such as secondary channels, spring brooks, and ponds.

The CTUIR's shift from site- to reach-scale restoration projects was also supported by the Accords Agreement that they signed with the Bonneville Power Administration (BPA) in 2007. This agreement emphasizes the importance of tributary habitats to recovering imperiled anadromous fish populations, and supports habitat improvement actions. As part of the Accords Agreement, the CTUIR has the unprecedented potential to improve the physical habitat conditions in ceded Columbia River tributaries (fig. 1).

With the Accords Agreement, the CTUIR also has the responsibility to demonstrate to the tribal community, BPA, Northwest Power and Conservation Council (NPCC), and Independent Science Review Panel (ISRP) that funded restoration projects have resulted in habitat changes and reductions in limiting factors. 'Limiting factors' refers to habitat impairments following its definition in the Accords Agreement. Owing to limited monitoring support, the CTUIR's project leaders collect data at a subset of restoration sites to document habitat improvements resulting from restoration actions. As of 2015, project leaders choose metrics and protocols for effectiveness monitoring from site-scale protocols, such as those from the Columbia Habitat Monitoring Program (CHaMP), Environmental Monitoring and Assessment Program (EMAP), PACFISH/INFISH Biological Opinion (PIBO), and Monitoring Methods (https://www.monitoringmethods.org/).

One limitation of these existing monitoring resources is that none were explicitly designed to consider the scale of restoration projects as a factor in the design, collection, and analysis of restoration effectiveness data. This gap means that existing monitoring methods do not change or adjust with increasing project size. For example, existing monitoring protocols do not include reach-scale metrics, such as sinuosity or side-channel length, which are key response variables for floodplain reconnection projects. Ultimately, physical responses to restoration at the reach scale may be missed if only site scale methods are used for effectiveness monitoring.

The goal of the Physical Habitat Monitoring Strategy (PHAMS) is to help fill this gap in available monitoring approaches for reach-scale restoration projects. Methods in PHAMS were drawn from peer-reviewed literature, and selected to emphasize measurements at the reach scale. Project leaders can select from these reach-scale methods, depending on the goals of their restoration project and the level of monitoring support. Methods in PHAMS are anticipated to be used in conjunction with existing effectiveness monitoring protocols when there is a need for complimentary reach-scale metrics and methods to detect reach-scale changes in physical and riparian habitats at large restoration projects. The primary audiences for PHAMS are the CTUIR Fisheries Habitat Program project leaders, NPPC, ISRP, and BPA technical staff. Information in PHAMS may also be useful to other agencies, regional effectiveness monitoring efforts, and improving our understanding of rivers and floodplains in the CTUIR's ancestral lands (fig. 1). 
The scope of PHAMS focuses on identifying and summarizing reach-scale effectiveness monitoring methods for physical features and riparian vegetation from the peer reviewed literature. PHAMS also summarizes methods, such as the River Complexity Index (Brown, 2002), that the CTUIR has used for several years, and new approaches that may be important to measuring physical changes associated with channel realignment actions. To avoid duplication, PHAMS does not address other biological methods or types of monitoring, such as implementation and status and trends monitoring. Readers interested in those types of methods and approaches can refer to existing resources, such as the methods for assessing changes in the abundance and distribution of spring Chinook salmon, steelhead-rainbow trout, and bull trout following restoration (Confederated Tribes of the Umatilla Indian Reservation, 2009) and methods for habitat conditions, food webs, fish abundance, and fish survival developed by the CHaMP and PIBO programs.

The PHAMS document is organized into four sections. The first section outlines the organizing principles of PHAMS. The second section summarizes watershed and reach-scale processes for each of the River Vision touchstones (described below in Organizing Principles). The third section summarizes common restoration actions, and reach-scale monitoring methods related to hydrology, geomorphology, hydrologic connectivity, and riparian vegetation. The fourth section illustrates the need for complementary monitoring approaches for reach-scale projects with examples drawn from the Meacham Creek restoration project. All sections provide some synthesis of the current scientific literature so that CTUIR project leaders can use this document as a reference for selecting monitoring methods and identifying relevant source material.

\section{Organizing Principles of the Physical Habitat Monitoring Strategy}

The Accords Agreement between the CTUIR and BPA is one of many factors influencing the CTUIR's Fisheries Habitat Program. In this section, we describe three additional principles that shape the Fisheries Habitat Program and corresponding PHAMS approach. These principles are:

1. The River Vision is the Conceptual Framework for Restoration Efforts by the Confederated Tribes of the Umatilla Indian Reservation

2. Processes at Different Spatial and Temporal Scales Control Physical Habitat

3. Scale is an Important Consideration for Selecting Monitoring Parameters

\section{The River Vision is the Conceptual Framework for Restoration Efforts by Confederated Tribes of the Umatilla Indian Reservation}

In 2007, the CTUIR recognized the need to create a holistic vision to guide their restoration of rivers and culturally significant First Foods throughout their ancestral lands (fig. 1) in response to tribal requests for improved and continued access to First Foods and the growing scientific literature emphasizing the importance of restoring process (Kondolf and others, 2006; Beechie and others, 2010). The resulting CTUIR River Vision is a comprehensive framework of the main physical and riparian processes that influence reach-scale morphology and habitat characteristics (Jones and others, 2008). Key attributes of a functioning river, or "touchstones," in the River Vision include hydrology, geomorphology, connectivity, and riparian vegetation. Mirroring the River Vision, PHAMS methods are organized into hydrology, geomorphology, connectivity, and riparian vegetation sections. 
The River Vision calls for rivers that are "highly dynamic and shaped by not only physical and biological processes but also interactions and interconnections among those processes" (Jones and others, 2008). Functioning and dynamic ecological processes are fundamental to restoring and sustaining First Foods for use by the tribal community. Therefore, the CTUIR Fisheries Habitat Progam and PHAMS recognize that dynamic interactions among the four touchstones are important to successful habitat restoration. For instance, some CTUIR restoration projects, like the Meacham Creek project, are restoring channel and geomorphic processes in order to increase hyporheic exchange and the diversity of water temperatures for summer steelhead-rainbow trout, spring Chinook salmon, and bull trout. These types of projects focus on engineering new habitat features and restoring hydrologic and geomorphic processes to influence stream temperature. At such projects, measuring thermal and hyporheic outcomes is important to demonstrate that restoration projects are having the desired effects on stream temperature and ultimately on target fisheries.

\section{Processes at Different Spatial and Temporal Scales Control Physical Habitat}

The second principle of PHAMS is that ecological and physical processes along different spatial and temporal scales structure riverine ecosystems, and that these processes and scales are critical considerations for effective habitat restoration (Wiens, 2002). Processes that control stream morphology and habitat can be visualized as a hierarchy with the following three dominant scales of control (fig. 2) (Beechie and others, 2010):

1. Reach-scale processes, such as river-floodplain interactions and influences of riparian vegetation.

2. Watershed-scale hydrologic and erosion processes that control water and sediment discharge.

3. The landscape template that controls valley slope and valley floor width.

Geology and topography shape the landscape template, which is essentially immutable over management time scales (tens to hundreds of years). The landscape template sets limits on the range of channel forms, habitat conditions, and vegetation that any reach can have.

Watershed-scale and reach-scale processes, then, determine the conditions within that range at any point in time. Watershed-scale processes influence discharge and sediment supply, which are the major controls on channel pattern (such as whether the channel is braided, meandering, or straight) and vegetation, but only to the extent that valley slope and floodplain width allow the development of these patterns. Reach-scale riparian and floodplain processes influence bank strength from roots (an influence on channel pattern), recruitment of wood to streams (which influences pool and island formation and increases habitat complexity), and shade or leaf litter inputs (which influence stream temperature and food webs). 
A. Reach scale: channel and flood plain processes

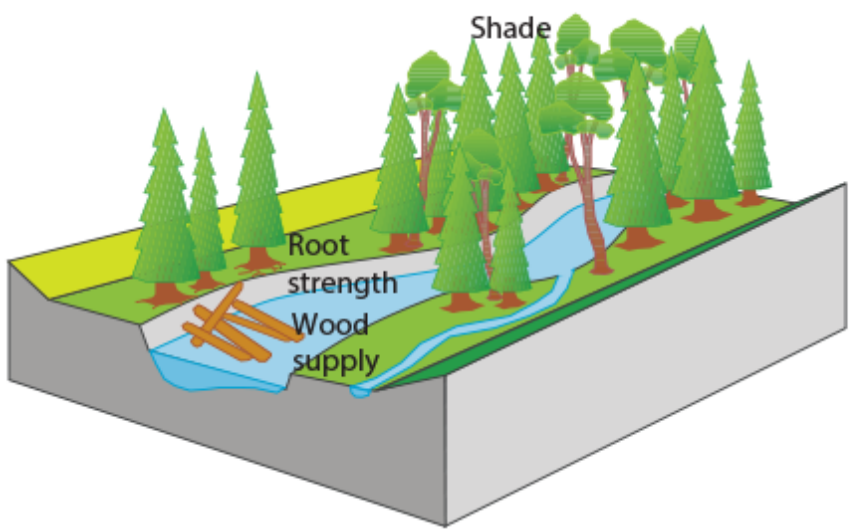

B. Watershed scale: erosion and runoff processes
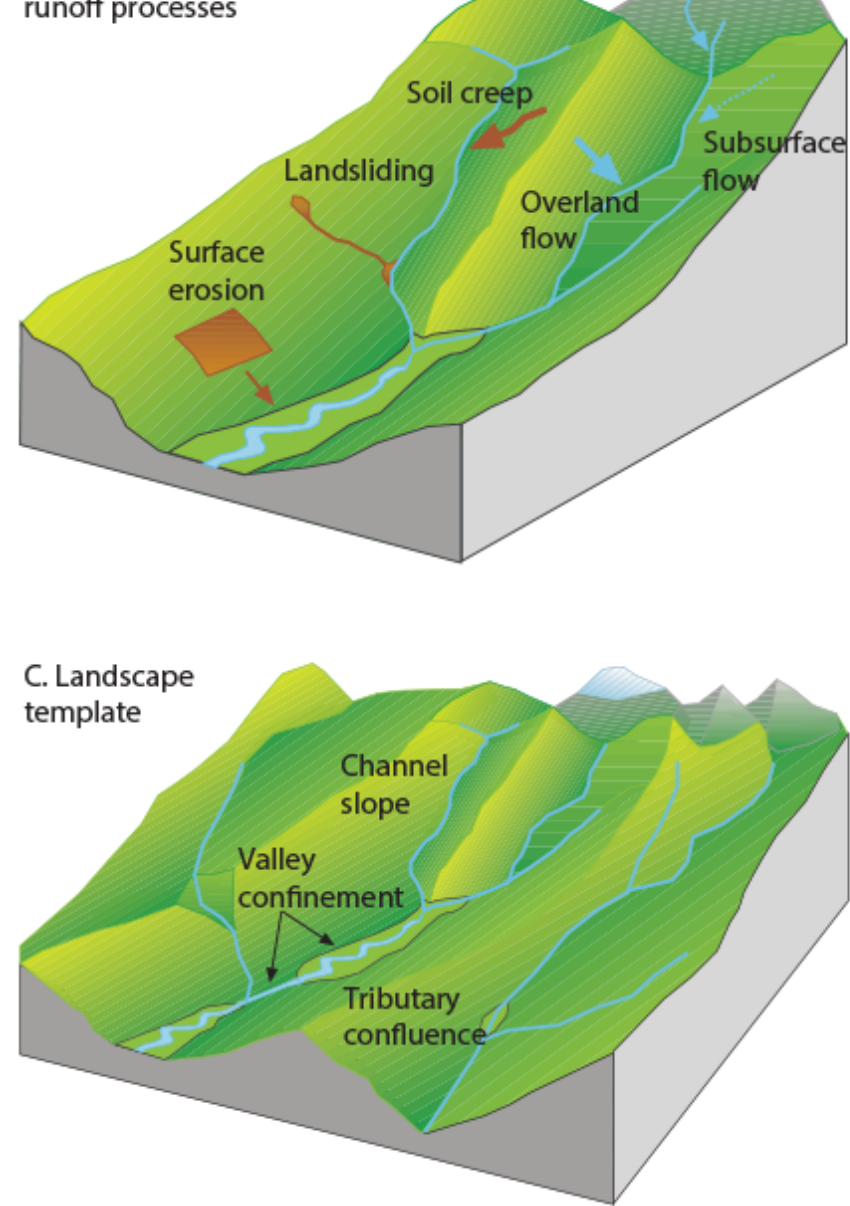

Reach-scale processes control habitat characteristics via wood supply and flood-plain processess. Land-use effects generally occur on short time frames (years to decades).

Watershed-scale processes control stream flow and sediment supply. Land-use effects can alter flow and sediment supply over decadal time frames.
Long-term processes acting over centuries to millenia create the geological and topographic template. Relatively immutable over management frames.

Figure 2. Illustration of the hierarchy of controls on river morphology and habitat, including $(A)$ reach-scale processes, $(B)$ watershed-scale processes, and $(C)$ the landscape template. Modified from Beechie and others (2010). 


\section{Scale is an Important Consideration for Selecting Monitoring Parameters}

The third principle of PHAMS is that spatial and temporal scales are important considerations for identifying which monitoring metrics to measure and when to measure them (Montgomery and Buffington, 1998; Church, 2002). For a particular restoration action, spatial scale refers to the scale at which restoration occurs, as well as the scale at which physical and biological conditions respond to restoration. Time scale refers to the length of time required for a response to be detected following project implementation. The response of a given site to restoration actions will depend on the context set by its process hierarchy (fig. 2).

In this report, we focus on the 'reach' or 'segment' scale (about $100-1,000 \mathrm{~m}$ ). For the purposes of PHAMS, the reach scale is appropriate for evaluating implementation and effectiveness of the CTIUR's largest active stream restoration efforts, such as the Meacham Creek project in the Umatilla River Basin. PHAMS focuses on the reach scale because some reach-scale responses cannot be captured by site-scale metrics. Some limitations of using only site-scale approaches for monitoring reach-scale restoration projects include:

- Site-scale approaches tend to focus largely on the main channel. As a result, they tend not to capture side channels, bars, spring channels, and other important active channel and floodplain features in semi-arid rivers.

- Approaches like EMAP and CHaMP collect data at the site-scale and at many sites to describe the status and trends of habitat conditions. An implication of this design is that EMAP or CHaMP sampling must capture the full range of site conditions in order to draw valid conclusions. Status and trend monitoring is beyond the purview of the CTUIR's Fishery Habitat Program, and it does not provide information directly applicable to evaluate targeted actions for improving habitat.

- Site-scale methods may not account for possible time lags in physical responses to restoration actions. They also have prescribed sampling frequencies and intervals that are not driven by process time scales. For example, riparian restoration may take several decades or more to achieve desired shade and wood supply conditions. Therefore, it is important to understand the time scale of processes being restored in order to establish appropriate monitoring intervals. Where recovery is expected to be slow, monitoring can be at infrequent intervals and continued over long periods to document project effectiveness. When recovery is rapid (like reconnecting habitat with improved adult passage), monitoring generally is more frequent and of shorter duration.

Because of these types of limitations, point measurements are often less efficient than reachscale metrics at capturing reach-scale responses. Reach-scale metrics, such as sinuosity, length of side channels, and reach-aggregated habitat areas, are direct measures of reach-scale responses to channel and floodplain restoration projects, and therefore are likely more cost effective to measure than more detailed point-by-point measures. We view these reach-scale metrics as complimentary to site-scale metrics in the CHaMP and PIBO Status and Trend Monitoring Programs. 


\section{River Vision Touchstones and Associated Key Processes}

The River Vision refers to attributes of functioning rivers as touchstones (Jones and others, 2008), and PHAMS recognizes that each of the four touchstones-hydrology, geomorphology, connectivity and riparian vegetation - contribute to the success of any reachscale restoration action. In this section, we first describe the importance of each touchstone to the River Vision, and then briefly summarize the key watershed- and reach-scale processes for each touchstone.

\section{Hydrology}

Water is the primary First Food (or culturally significant food of the CTUIR) that is required to create and sustain all other First Foods. In particular, the aquatic life of a basin is sustained by water from many sources, such as discharge from springs, snowmelt, groundwater, interflow through the soil, and all orders of streams. Variation in the timing and volume of water determines the hydrologic regime and influences physical and ecological processes, particularly in the semi-arid basins of the CTUIR's ancestral lands (fig. 1). Water also performs work on the landscape as it moves through a watershed, thereby influencing conditions for biota and ecological processes (Dunne and Leopold, 1978).

The hydrology touchstone of the River Vision addresses both water quality and water quantity. Water quality includes water temperature, turbidity, dissolved nutrients, and contaminants. Water quantity encompasses the volume and timing of surface waters and groundwater throughout the water year. Understanding and managing water on the landscape and as a natural resource requires consideration of both physiochemical conditions (quality) and hydrologic conditions (quantity). These are also key parameters to include in PHAMS because many of the CTUIR's restoration projects seek to address limiting factors related to water quality and quantity.

The River Vision also considers the importance of hyporheic exchange (or water movement between stream channels and the hyporheic zone) to ecosystem condition and functioning (fig. 3). The hyporheic zone has sediment materials with high conductance, which allows significant mixing of river water and groundwater at multiple temporal and spatial scales (Dent and others, 2001). In alluvial rivers, the distinction between groundwater and surface water is often ambiguous (Boulton, 1993) because river water and groundwater flow freely through the hyporheic zone and zones of preferential flow. Zones of preferential flow, or paleochannels, are older channel beds filled with gravel and buried in the modern floodplain (fig. 3). Other surface water features like spring brooks, ponds, and wetlands occur wherever saturated paleochannels intersect the floodplain surface. 


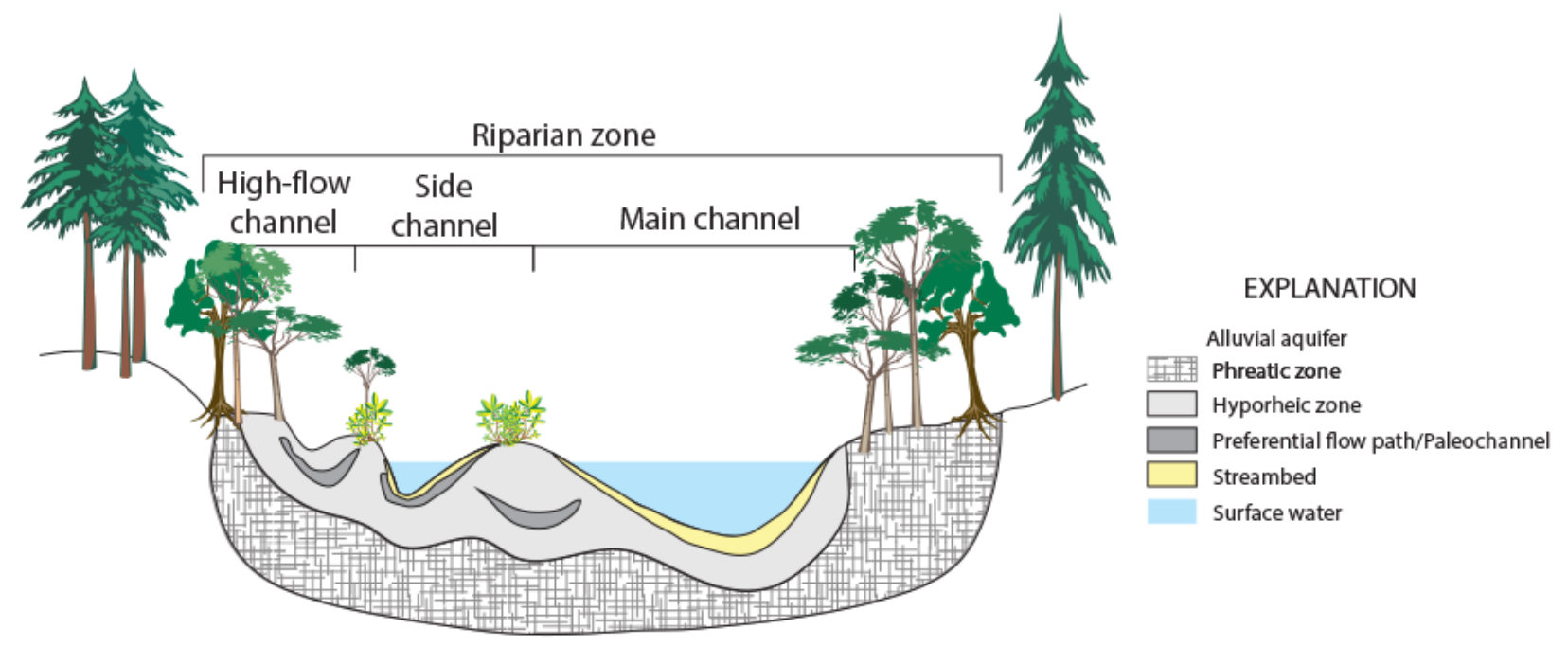

Figure 3. Cross-section of a hypothetical functional floodplain showing a range of channels. Adapted from Poole and Berman (2001).

\section{Key Hydrologic Processes}

Seasonal flooding structures floodplain features (Leopold and others, 1964), defines the flow regime for the following year (Junk and others, 1989), and organizes aquatic habitats across the floodplain (Mouw and others, 2013). In the semi-arid basins, the greatest flows tend to occur in the winter and early spring. These floods inundate floodplains and saturate alluvial aquifers, which later release water as the river stage decreases to base flow, creating a dynamic distribution of hydrologic pathways (fig. 3). These hydrologic pathways, as expressed by channel networks and hyporheic flow paths, convey water through the floodplain and often intersect paleochannels that further modify water movement through a basin. Overbank flood pulses also arrange river ecosystems by reorganizing sediments and wood on floodplain surfaces and moving nutrients, organic matter, sediment, and water from hillslopes to tributaries and later to main stem floodplains (Benda and others, 2004). These annual pulses of materials create the dynamic structure of floodplain habitats and sustain some of the most biologically diverse zones on the planet (Ward and Stanford, 1995). For instance, floodplains in the Blue Mountains of eastern Oregon cover only 4 percent of the landscape, but harbor more than 90 percent of the vertebrate species (Langston, 1995). Arresting the seasonal flood cycle is among the most ecologically disruptive, yet common conditions of modern rivers.

At the watershed scale, climate, land cover, geology, precipitation, and topography combine with the size, shape, and configuration of the basin (Benda and others, 2004) to regulate stream discharge and storage of water. The geologic and topographic template determines the location and size of individual floodplains, as "beads on a string" (Regier and others, 1989). Furthermore, basin size, shape and orientation, tributary confluence type, the amount and distribution of development, and underlying geology influence the flow of water through a watershed (Benda and others, 2004). Throughout the Blue Mountains and Columbia Plateau, water delivery is further modified by impoundments and water diversions ranging from cattle watering ponds to large federally regulated reservoirs, such as the McNary Pool of the Columbia River. These impoundments and water diversions change the timing and amount of streamflow. 
Within distinct geomorphic reaches, the discharge delivered into the reach, tributary influences, and local storage influence streamflow. Water can be gained or lost in alluvial reaches, owing to local controls such as hyporheic exchange, geologic features like faults and springs, hillslope failure, delivery of material to the floodplain, water diversions, and land use. The diversity of hydrological features across floodplains includes spring brooks and secondary channels. These floodplain features are unique and critical habitats for juvenile fish (Beechie and others, 1994) and important sources of terrestrial inputs, aquatic invertebrate activity, and a variety of biogeochemical transformations. These characteristics of mature floodplains are exceedingly rare in modern rivers, yet they constitute local peaks of physical and biological activity.

Both watershed- and reach-scale processes affect water quality. For example, stream temperature is influenced by elevation, network structure, and groundwater inputs at the watershed scale, as well as by riparian conditions at the reach scale. Notably, suspended sediment and water temperatures are water-quality parameters that have complex effects on aquatic ecosystems, and quantifying their effects on biota is an active field of research. Elevated nutrient levels, pathogens, contaminants such as heavy metals and pesticides, and low levels of dissolved oxygen are other limitations on water quality associated with altered rivers.

\section{Geomorphology}

The geomorphology touchstone focuses largely on the concept of intact river-floodplain systems with migrating, multi-thread channels. This vision is applicable to unconfined valley segments (floodplain width more than about 4 times the channel width) but not to confined segments. The River Vision's focus on large and dynamic reaches (hundreds to thousands of meters long) pushes us to consider processes that drive patterns of habitat and species, and to identify monitoring parameters and methods to detect changes in both processes and patterns. The River Vision also recognizes that the river-floodplain ecosystem is complex and dynamic, and characterized by interactions between hydrologic processes (flooding and hyporheic exchange), geomorphic processes (channel migration and floodplain formation), and riparian processes (succession, mortality, and wood recruitment). Interactions between these processes create high habitat diversity and provide opportunities for multiple species and life stages of salmon and other First Foods to thrive.

\section{Key Geomorphic Processes}

A hierarchy of natural controls influences the distribution of floodplain features, complex channel patterns, and physical habitats on a riverine landscape. The first level control is the topographic and geological template, which defines locations of floodplain and confined reaches, as well as the distribution of channel slopes in the river network. The second level controls are the watershed-scale processes of runoff and erosion, which control discharge and sediment supply to reaches. These watershed-scale processes largely determine channel pattern, such as whether the channel is straight, meandering, or braided. The third level controls are site- and reach-scale processes such as channel migration, wood recruitment from the riparian zone, and sediment transport or retention. 
Erosion-or the delivery of sediment to channels-is a watershed process that affects a variety of reach characteristics. Erosion is classified into three types: soil creep, surface erosion, and mass wasting (fig. 4; Dunne and Leopold, 1978). Soil creep is the gradual down-slope movement of the soil mantle by gravity. Surface erosion on bare soils is more predictable than mass wasting because it occurs during virtually all rainstorms and snowmelt, and the severity of erosion varies predictably with rainfall intensity, slope, and soil type (Dunne and Leopold, 1978). Surface erosion (including sheetwash, rilling, and gullying) is relatively rare in naturally forested and grassland environments, but is a common occurrence in semi-arid to arid lands and in alpine areas. Mass wasting processes, such as landsliding are episodic, driven by storm event frequencies and high spatial variation in number and failure potential of landslide sites (Bergstrom, 1982; Benda and Dunne, 1997). The combination of variation in storm intensity and site susceptibilities to failure lead to high spatial and temporal variation in sediment supply by mass wasting (Benda and Dunne, 1997).

After sediment enters channels, it can have different effects on channel morphology, depending on its size and hardness. Coarse sediment supply can influence such characteristics as width to depth ratio, pool depth, and grain-size distribution. In contrast, fine sediment supply tends to influence either accumulation of fines in pools (pool filling) or increase proportion of fine sediment in the bed material. Bed-load transport of coarse sediment results in particle attrition (the breakdown of larger particles into smaller ones) and contributes to longitudinal fining of the streambed (O'Connor and others, 2014), although harder rock types tend to withstand river transport whereas softer rocks tend to break down more rapidly into sand and finer particles.

Soil creep

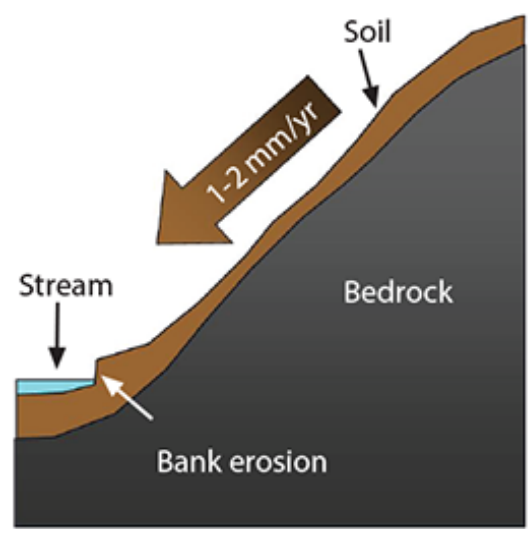

Surface erosion

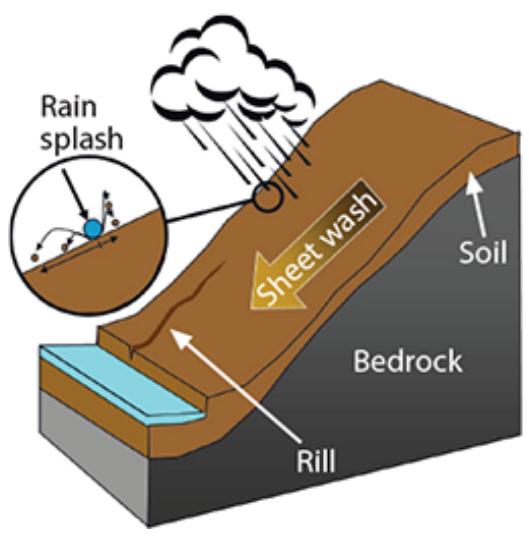

Mass wasting

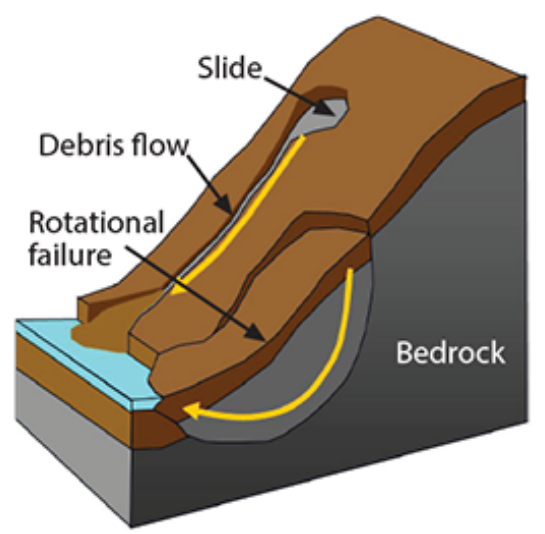

Figure 4. Conceptual diagram showing erosion processes including soil creek, surface erosion, and mass wasting (or land sliding). Modified from Beechie and others (2013). 
The rate of sediment transport relative to the rate of sediment supply to a reach (termed the relative transport rate or relative sediment supply) determines whether any individual reach is accumulating sediment, exporting sediment, or relatively stable (fig. 5). Channel beds aggrade when sediment supply exceeds transport capacity, but incise when sediment supply is less than transport capacity. At a low relative sediment supply (when sediment supply is low or sediment transport capacity is high), the bed surface tends be relatively coarse and the fine sediment content of streambed gravels relatively low (Dietrich and others, 1989). As the ratio of sediment supply to transport capacity increases (when a reach is increasingly oversupplied), increased fine sediment can be accommodated through fining of the bed surface, pool filling, channel aggradation, and finally channel widening (Lisle, 1982; Madej, 1982; Dietrich and others, 1989; Madej and Ozaki, 1996). Channels also may become laterally unstable (Bergstrom, 1982; Church, 1983), which might scour some vegetation but create new germination locations for other species and cause channel migration and avulsion that help create new and geomorphic features. Channels with low relative sediment supply are typically narrow with armored bed surfaces (Lisle, 1982; Pitlick and Thorne, 1987; Beechie and others, 2005).

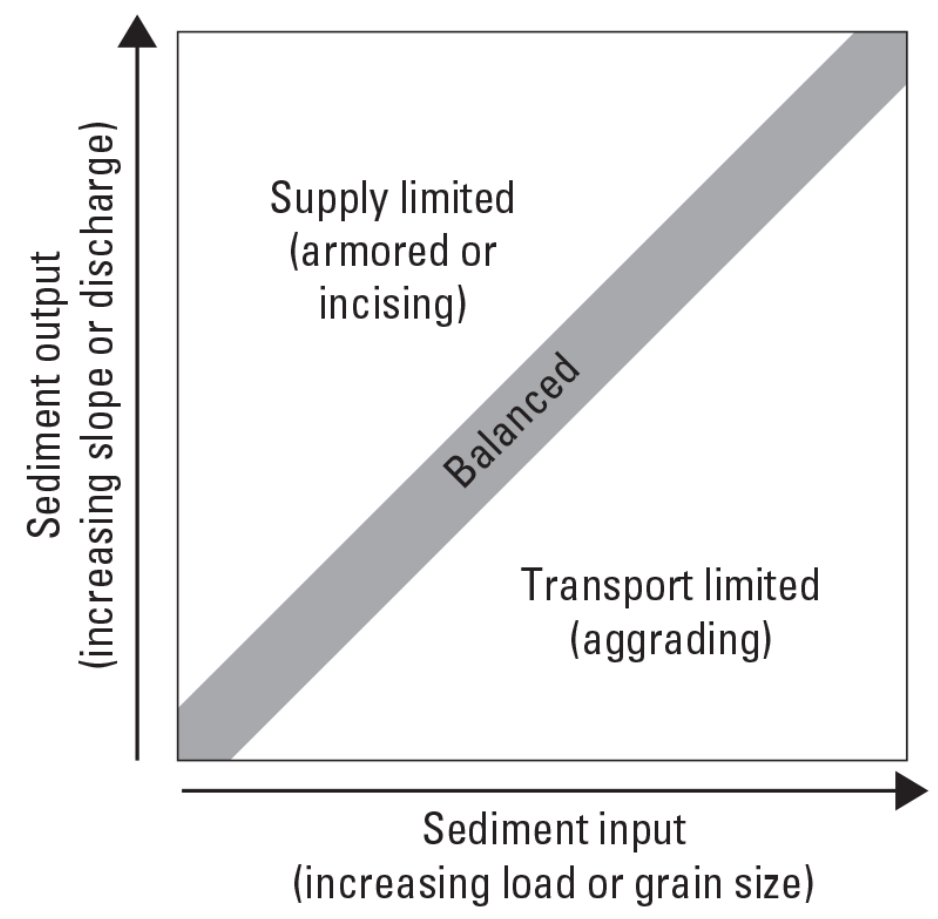

Figure 5. Graph showing balance between sediment supply and transport capacity, showing that reaches receiving more sediment than they can transport will aggrade, and reaches that can transport more sediment than they receive will incise or become armored. 
Sediment transport in channels is primarily a function of stream power, which is a function of channel slope and stream discharge. Increasing slope or discharge will increase both the size and amount of sediment that can be transported in alluvial channels. Vegetation, wood debris, or beaver dams may also regulate sediment transport. In low-gradient channels, suspended sediment may be trapped by inchannel or floodplain vegetation, or by beaver dams (Pollock and others, 2007; Beechie and others, 2008; Gurnell and others, 2010). Both mechanisms reduce sediment transport capacity relative to sediment supply and result in bed and floodplain aggradation. Similarly, downed wood in forest channels can increase storage of bedload sediment and can convert bedrock channels to alluvial channels or reduce the grain size of the bed material (Montgomery and others, 1996; Buffington and Montgomery, 1999).

Exchange of sediment between the floodplain and channel is also an important process, regulating sediment transfer through reaches. Sediment stored in the bed and bars is activated by bedload transport during moderate to large floods, whereas floodplain sediment is mobilized by bank erosion during large floods (Madej, 1987). Smaller channels (less than 8-15 m bankfull width, depending on eco-geomorphic setting) have little capacity to erode their banks because stream power is insufficient to erode through root-reinforced banks. These characteristics make small channels laterally stable or have low lateral migration rates (Beechie and others, 2006; Hall and others, 2007). By contrast, large channels are often deep enough to erode below the rooting zone, and can have high lateral migration rates (Beechie and others, 2006). Floodplain turnover rates (the amount of time it would take to erode the entire floodplain one time) can be less than a decade for braided rivers with high lateral migration rates, or several decades to a century for straight or meandering rivers with low migration rates (Beechie and others, 2006). These dynamics create what has come to be known as the shifting habitat mosaic, in which some habitats are destroyed and others created each year, but the pattern and distribution of habitat types remains more or less constant through time (Ward and others, 2002). These geomorphic dynamics play out over decadal time scales and longer, creating a complex suite of habitats and thermal regimes, which in turn contribute to high biological diversity (Poole and others, 2008).

\section{Connectivity}

The connectivity touchstone addresses "hydrologic connectivity," or the "water mediated transfer of matter, energy, and organisms within or between elements of the hydrologic cycle" (Pringle, 2003). The River Vision emphasizes four types of connectivity-longitudinal connectivity along the river network, lateral connectivity between the river and floodplain, vertical connectivity between the river and hyporheic zone or groundwater aquifers, and temporal connectivity. Several conceptual models describe these four types of hydrologic connectivity: 
The River Continuum Concept (Vannote and others, 1980): The River Continuum Concept (RCC) proposes that understanding longitudinal changes in physical habitat along a river system is necessary to understand associated biological changes and river dynamics (fig. 6). This concept compartmentalizes species along a longitudinal gradient according to food sources, water quality, water quantity, life cycle needs, and habitat availability. The RCC does not translate well to large streams because it was developed for small temperate streams (Junk and others, 1989). The RCC was later refined by the Serial Discontinuity Concept to include regulated discontinuities in rivers, such as dams and impoundments (Ward and Stanford, 1995).

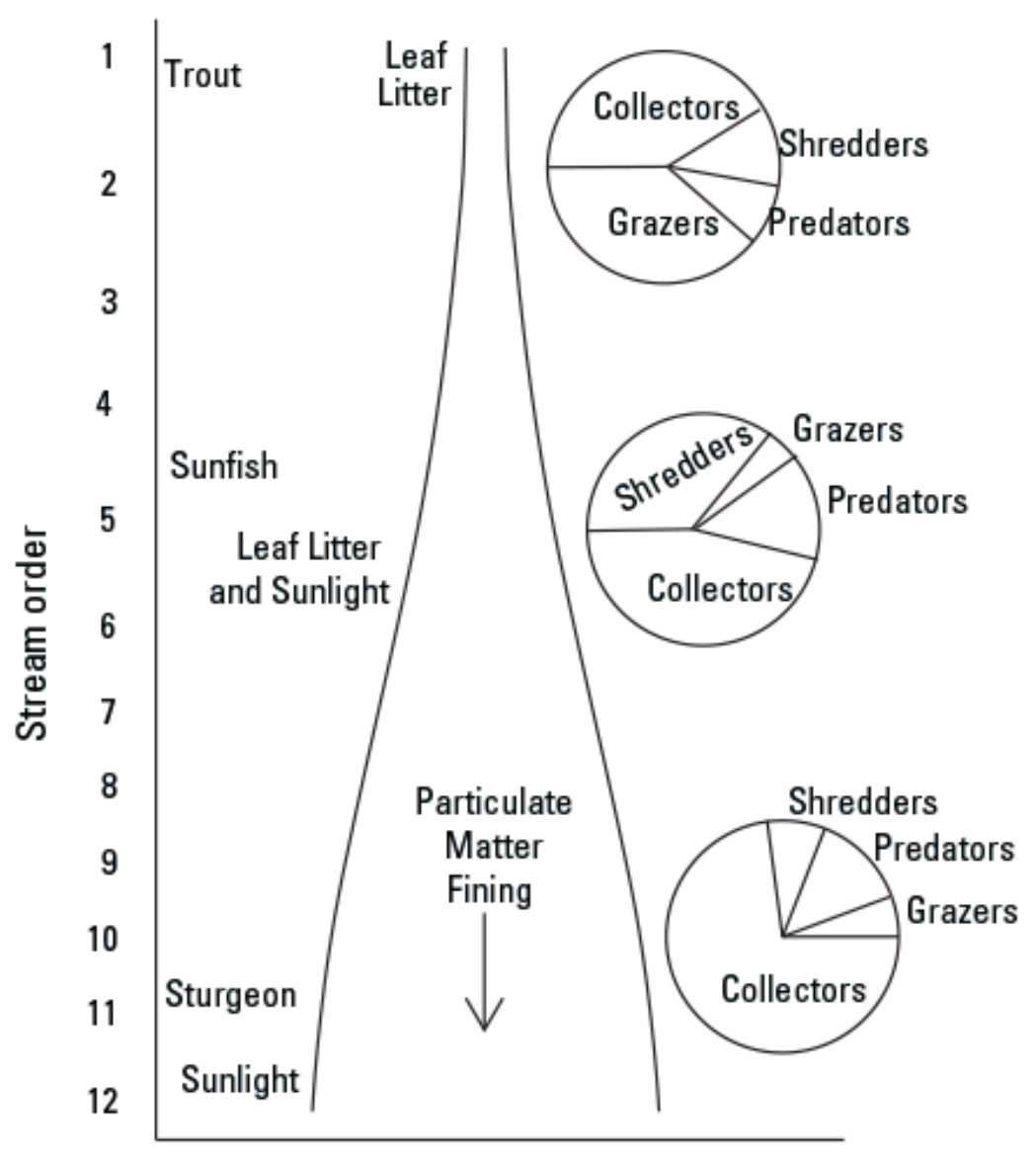

Figure 6. Characterization showing the River Continuum Concept. Adapted from Vannote and others (1980). 
- The Network Dynamics Hypothesis (Benda and others, 2004):The Network Dynamics Hypothesis (NDH) proposes that network structure, or the arrangement of tributaries and tributary junctions, exerts strong influences on habitat and biological conditions in receiving channels. A key implication of the NDH is that the river continuum is punctuated by abrupt changes in physical or biological features downstream of tributaries.

- Flood Pulse Concept (Junk and others, 1989): The Flood Pulse Concept emphasizes the importance of lateral connectivity between rivers and their floodplains, and recognizes that flood pulses connect the stream channel and floodplain during high flow events (fig. 7) and act to influence floodplain habitats, nutrient recycling, and biological communities. Differing from the emphasis on nutrient spiraling in the RCC, the Flood Pulse Concept suggests that the vast majority of aquatic biomass relies on floodplain production. Floodplain inundation is strongly tied to cyclical climactic forces that drive hydrology as well geomorphic features such as channel and floodplain types, channel entrenchment, slope, and floodplain features such as paleo-channels. Tockner and others (2000) extended the Flood Pulse Concept developed for tropical lowland rivers to include temperate rivers as well as habitat changes caused by the peaks and recessions of large flood events.

- Integration of the importance of longitudinal, lateral, vertical, and temporal connectivity by Ward (1989): This paper stresses that these four dimensions of connectivity are important for understanding how rivers are shaped by these pathways. The vertical component emphasizes the interactions between river channels, hyporheic zones, and larger groundwater systems.

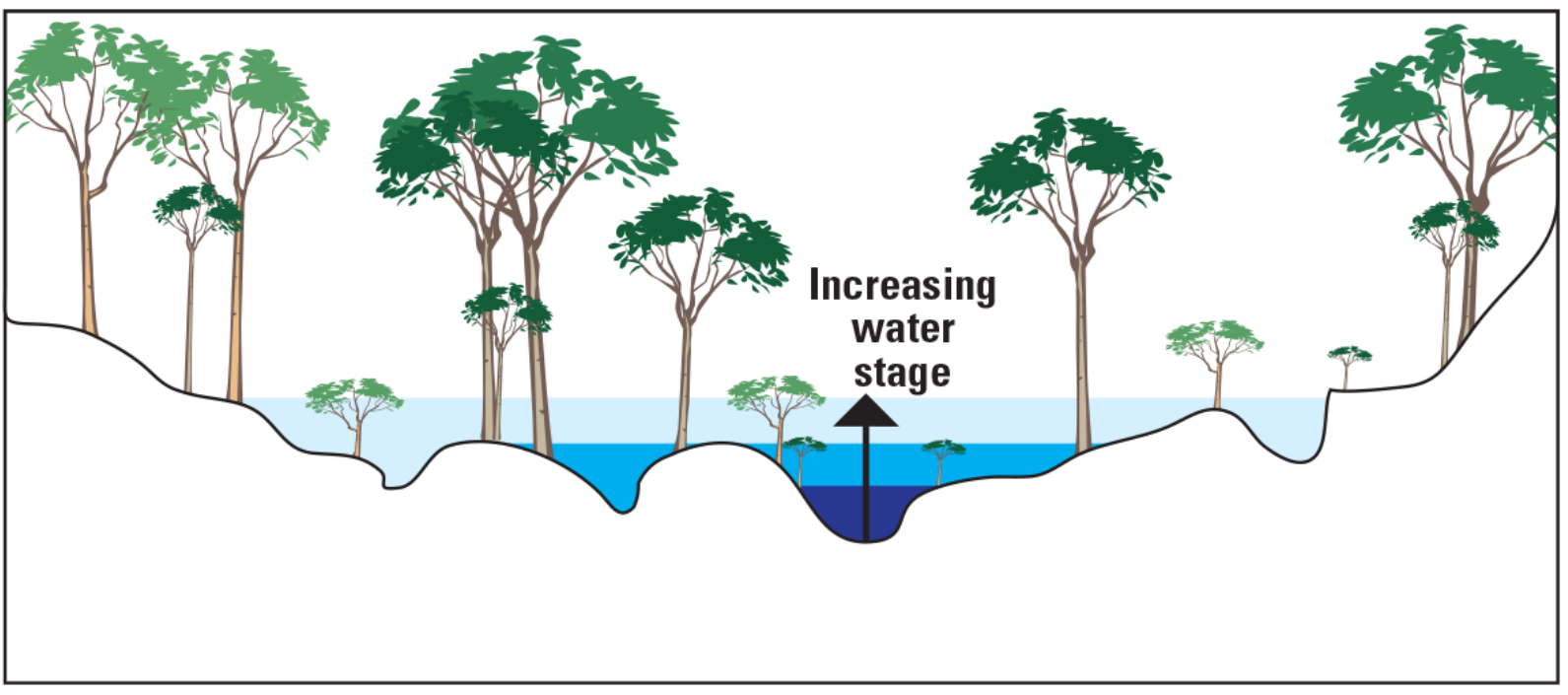

Figure 7. Characterization showing flood pulses and floodplain inundation with progressively increasing stream discharge events indicated by lighter coloring. 


\section{Key Connectivity Processes}

In this section we focus on longitudinal connectivity because processes affecting lateral, vertical, and temporal connectivity are discussed in the hydrology and geomorphology sections of PHAMS. Longitudinal connectivity includes passage within and between individual high quality functioning habitats as identified by other touchstones or during major life history events, such as when anadromous fish smolt or return to spawn. Longitudinal connectivity also includes downstream transport of water, suspended sediment and bedload, and debris of various forms necessary to create and maintain habitat for species of concern and their food base (Vannote and others, 1980; Benda and others, 2004). To a certain extent, this also includes access to offchannel habitats used for particular life stages such as low-velocity backwater and wetland areas. Although natural barriers such as waterfalls can restrict passage between habitats, many modern barriers are lower in the river network and result from the influence of human activity.

Processes that influence the arrangement of aquatic habitats on the landscape - and passage of biota between those habitats - operate at both the regional and watershed scales (Poff, 1997). That is, the spatial distributions of individual habitats used throughout the life histories of different species are formed by geologic and geomorphic processes (fig. 2). For example, the regional geological and topographic template controls valley slope, and knick points and network structure influence local stream channel gradients within limits set by the valley slope. Addressing natural controls on channel slope is beyond the scope of CTUIR's Fishery Habitat Program, but individual restoration actions must address land-management practices that influence habitat conditions and identify appropriate site-scale restoration actions that rely in part on understanding the influence of stream-channel gradient on restoration potential. An individual action may also need to consider watershed wide land-management practices, such as historical large-scale placer mining, and work within constraints imposed by altered processes resulting from past management actions.

Geologic and geomorphic features throughout a watershed also have bearing on water quantity and quality, and therefore should be considered when planning restoration actions. Generally speaking, one would expect increased water temperatures with decreasing elevation because air temperature generally increases at lower elevations. However, water storage increases in floodplain reaches or where deeper soils exist, resulting in increased hyporheic exchange and reduced heat flux into the channel. Narrow canyons may also moderate water temperatures, at least temporarily. Hence, the temperature profile of an entire stream channel from its origin to the confluence with another water body may show temperatures repeatedly increasing and decreasing within a gradually warming temperature profile (Fullerton and others, in review). 
Aquatic species can use many individual reaches within a watershed during their life cycle, and they rely largely on the arrangement of suitable habitats created by the processes described above. For example, bull trout migrate between habitats, spawning in higher elevation, cold-water environments and over wintering in lower elevation sites less prone to icing. This does not imply that a single valley segment would contain only one type of habitat or geomorphic feature. For instance, a single meadow may include a relatively straight losing reach (a reach in which discharge decreases in the downstream direction due to infiltration) on an alluvial fan, as well as a lower gradient, more sinuous gaining reach (a reach in which discharge increases in the downstream direction due to upwelling of hyporheic flow) with significant habitat complexity at the downstream end of the meadow. Hence, fish are not evenly distributed among reaches, and connectivity between the full suites of habitat types is important to the persistence of fish populations.

Because aquatic species use a wide range of habitats within and between reaches, migration pathways between these habitats must be maintained for populations to persist. Aside from natural physical barriers such as falls, migration may be limited by manmade barriers, thermal barriers, or flow barriers (too little flow). Culverts and dams are obvious manmade structures that can prohibit passage within and between individual stream reaches, but humancaused flow and temperature barriers may be more complicated to diagnose. Reach-scale processes that influence water depth and velocity or temperature include streamflow, channel incision or aggradation, tributary inputs, and riparian shade. Although these processes can naturally contribute to flow and temperature barriers, in other cases upstream passage may not be available due to land management practices. For example, during the summer as groundwater elevations drop, a losing stream channel on an alluvial fan may go dry. Precipitation amounts may be responsible for loss of stream flow during low water years; however, this problem obviously can be exacerbated by withdrawing water from the stream for other uses. Similarly, aggradation of the channel on an alluvial fan (due to too much bed load supply) can contribute to loss of surface flow and interruption of migration. By contrast, incision can result in decreased water storage in alluvial aquifers and reduced streamflow to the point where passage is no longer available annually (Beechie and others, 2008). Thermal barriers also can be created by loss of riparian shade. Decreasing connectivity to and between these areas by man-made structures or land management practices disrupts life cycles and, if severe enough, compromises the viability of a population. 


\section{Riparian Vegetation}

The River Vision calls for self-sustaining communities of native riparian vegetation. Some common native plants in the CTUIR's ancestral lands are sedges, rushes, Red Osier dogwood, Golden currant, Drummonds willow, Coyote willow, alder, and cottonwood. The River Vision recognizes that native riparian vegetation species have many important functions, such as increasing bank stability, shading streams and cooling temperature, and delivering seasonal fluxes of organic material that fuel the river's food web (Gregory and others, 1991). In particular, large wood can become lodged in streams where it can form pools that increase habitat complexity for salmon and other aquatic organisms as well as nutrient and sediment retention (Gurnell and others, 2002; Collins and others, 2012). Although the River Vision focuses on trees and shrubs, herbaceous vegetation like sedges and rushes grow along channel and floodplain features, and help create new geomorphic features like bars and islands and increase bank and channel stability (Micheli and Kirchner, 2002a, 2002b; Gurnell and others, 2012).

\section{Key Riparian Vegetation Processes}

Definitions of riparian zones include the area from channel margins to the limits of flooding (Gregory and others, 1991) and those streamside areas where plants depend on shallow groundwater tables, such as in arid regions (Stromberg and others, 2007). Like the geomorphology touchstone, a hierarchy of processes influences distributions of native riparian vegetation. Watershed level controls include climate, elevation, and geology, which control valley confinement and the width of the riparian zone. These controls result in patterns like riparian zones being largest in unconfined valley segments and narrower in confined valley segments. Reach level controls include hydrologic, geomorphic, and biological processes.

Geology, climate, topography, and natural disturbances largely shape the distribution and patterns of vegetation at the watershed scale (Tabacchi and others, 1998; Steiger and others, 2005; Corenblit and others, 2007). The CTUIR's ceded lands are mostly in the semi-arid Blue Mountains and the Columbia Plateau ecoregions where temperature, precipitation, hydrology, and elevation are the key watershed controls on vegetation (Wissmar, 2004; Loheide and others, 2009). This means that vegetation is different in upland and lowland areas, and occurs mostly around surface-water features and near shallow groundwater aquifers.

At the reach scale, riparian vegetation is influenced by many hydrologic process, including overbank floodplain, groundwater recharge, and connectivity. Seasonal flooding helps prevent the establishment of more xeric (or dry) native species and invasive species (Loheide and others, 2009). Seasonal flood pulses also create the sediment deposits where species like cottonwood can germinate (Braatne and others, 1996). Meanwhile, groundwater helps sustain vegetation throughout the dry months as they reproduce and grow (Stringham and others, 2001; Dwire and others, 2006; Loheide and others, 2009). Unlike mesic species, the roots of native xeric species (like lodgepole pine and sagebrush) and invasive species (like Kentucky bluegrass) can reach the deeper water tables (Stringham and others, 2001; Dwire and others, 2006). 
Geomorphic processes also influence riparian vegetation at the reach scale. Geomorphic processes like channel migration and avulsion result in a range of topographic features like abandoned side channels, newly exposed river banks, and spring channels that are nursery sites for vegetation, and help sustain groundwater inputs in summer (Gurnell and others, 2006; Loheide and others, 2009; Stella and others, 2011). The balance between flow and sediment helps prevent channel incision, which is associated with declines in water table elevation, and ultimately a shift from mesic to xeric vegetation (Loheide and Gorelick, 2005, 2007).

In addition to hydrologic and geomorphic processes, other species can affect riparian vegetation at the reach scale. Invasive vegetation can sometimes out-compete native vegetation for space and resources. In the John Day River Basin, the cover of invasive species tends to be greatest near roads and on south facing slopes in large basins where there is considerable grazing and farming and narrow riparian buffers (Magee and others, 2008). Livestock and wild ungulates often graze upon herbaceous vegetation and some seedlings like cottonwood (Kauffman and Krueger, 1984; Opperman and Merenlender, 2000; Brookshire and others, 2002). On the other hand, beaver may have short-term negative effects on riparian vegetation (such as grazing and using vegetation to build dams), as well as longer term positive effects associated with beaver dams, such as channel aggradation and increased hyporheic exchange (Pollock and others, 2007; Poole and others, 2008; Pollock and others, 2012).

Figure 8 compares hypothetical unhealthy and healthy meadow systems in order to illustrate the different controls on vegetation at the reach scale. The unhealthy meadow (fig. $8 \mathrm{~A}$ ) has a lower water table, reduced interactions between the surface water and groundwater, an incised channel that increases cross sectional area (this in turn reduces overbank flooding and sediment deposition), eroding and tall banks, a straight channel, and xeric vegetation that can reach the deeper water table because of their long roots. In contrast, the healthy meadow (fig. $8 B$ ) has a high water table that can be reached by the roots of mesic vegetation, vertical and lateral connectivity, banks stabilized with vegetation, a sinuous channel, and low channel crosssectional area (that promotes overbank flooding and sediment deposition). 

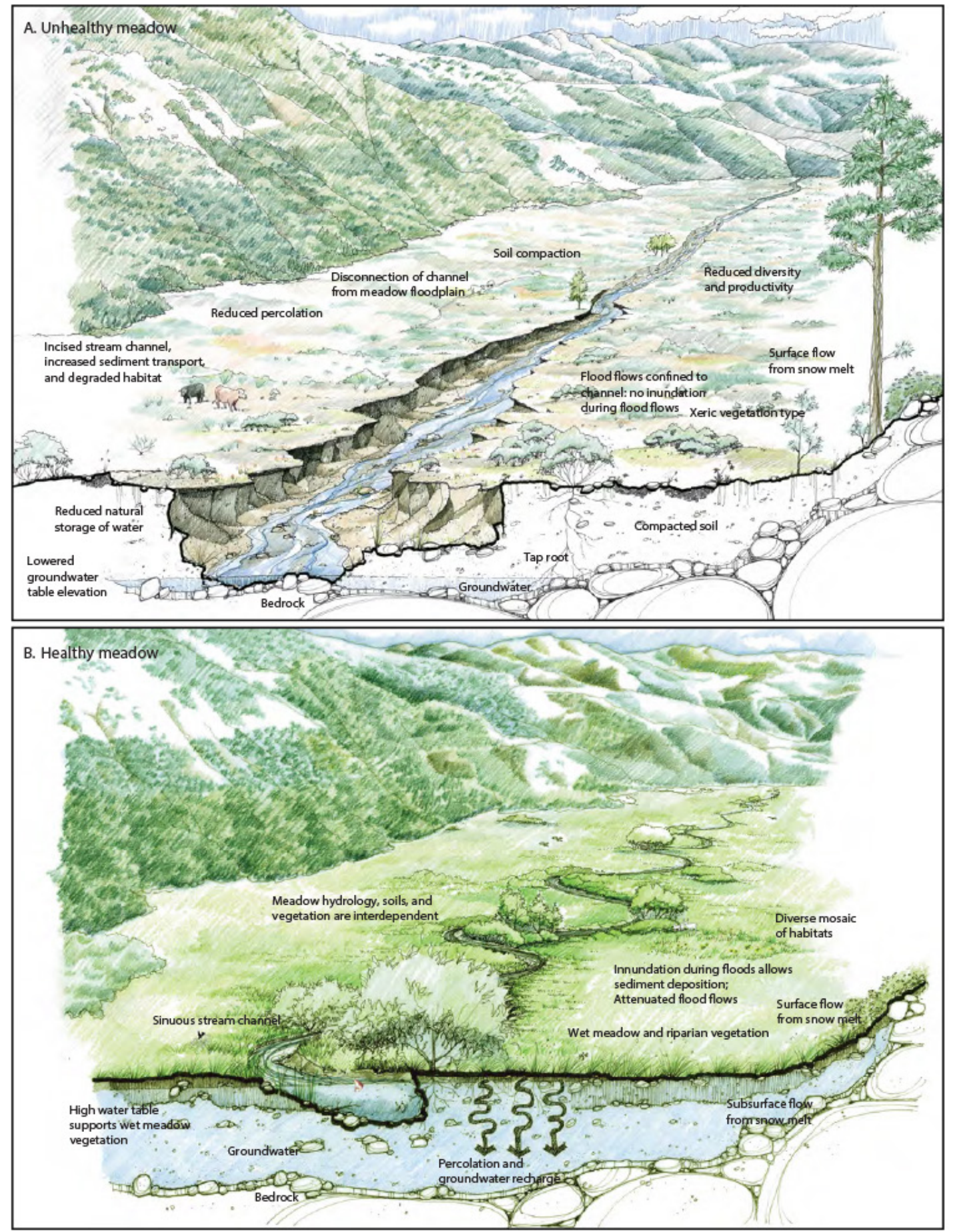

Figure 8. (A) Unhealthy meadow with reduced natural storage of water, lowered groundwater table, flood flows confined to channel with no inundation during floods, and xeric (or dry) vegetation. $(B)$ Healthy meadow with diverse mosaic of habitat with wet meadow and riparian vegetation, high water table, inundation during floods with sediment deposition and attenuated flood flows, and percolation with groundwater recharge. Illustration used with permission from the Restoration Design Group. 


\section{Components of the Physical Habitat Monitoring Strategy}

The Physical Habitat Monitoring Strategy identifies and summarizes reach-scale monitoring methods drawn from the peer-reviewed literature. Each metric and method is appropriate for monitoring at least one of the common restoration actions within each of the River Vision touchstones: hydrology, geomorphology, connectivity, and riparian vegetation. For each touchstone, we describe common habitat restoration objectives, restoration actions that address those objectives, and monitoring parameters suitable for determining whether those objectives were achieved. Because restoration projects by the CTUIR vary in their objectives and scope, the monitoring parameters selected for each project may vary. However, for similar project types, the same metrics can be used in order to build a data base of projects and eventually a statistically robust analysis of the effectiveness of project types. When a single project is monitored, the only question that can be answered is "What is the effect of this project on local habitat conditions?" However, when multiple projects of the same type are monitored, a more general question can be answered: "What is the effect of this project type on local habitat conditions and biota?"

A strategic approach to monitoring individual restoration actions should follow the key monitoring steps outlined in Roni et al. (2013), including:

1. Identify project goals and objectives,

2. Develop hypotheses of expected project outcomes,

3. Choose monitoring parameters,

4. Choose the monitoring design (such as before-after or post-treatment),

5. Choose the sampling scheme (such as systematic or randomized),

6. Implement monitoring, and

7. Analysis and reporting.

For each restoration action that will be monitored, clear and quantifiable statements of habitat changes of restoration actions are needed as the outcomes of steps 1 and 2. One simple guideline is to assure that step 1 focuses on identifying "SMART" objectives, which are specific, measureable, achievable, relevant, and time-bound (Skidmore et al. 2013). For example, a project objective might be to "increase side channel habitat length by 1500 meters within 5 years." This objective is specific, measureable, and time-bound, but also should be achievable and is relevant to salmon recovery as it restores an important habitat type. Where SMART objectives are identified, the hypotheses of expected outcomes may be simple restatements of the objective.

Steps 3, 4, and 5 produce the monitoring plan, which includes the selection of monitoring parameters, the sample design, and the sampling scheme. Monitoring parameters should be directly related to the hypothesis (for instance, side channel length would be monitored for the objective above), and the sample design and sampling scheme should be appropriate for testing the hypothesis. Following on the same example, the sample design for a single project might be a before-after design (no control), or a before-after control-impact design (which includes an untreated control site), and the sampling scheme would be a complete census of side channels within the restoration reach repeated every year for at least 5 years. Once the monitoring plan is developed, the remaining steps are simply to implement the monitoring, and then to analyze and report the results. 
To the extent possible, a broader monitoring strategy might include a set of criteria for selecting projects to monitor, with the intention of monitoring multiple projects of the same type and more generally characterizing project effectiveness. The aim of such a strategy would be to assess the effectiveness of a specific project type, particularly those that are frequently implemented or costly to implement. That is, project types that comprise a significant portion of CTUIR restoration effort and spending could be a focus for monitoring to assure that restoration dollars are spent wisely.

To help guide the implementation of this strategy, the following sections provide a summary of project types, objectives, monitoring parameters and methods within each of the four River Vision touchstones. These sections should help streamline Steps 1, 2, and 3 for planning restoration project monitoring. Completion of steps 4 and 5 will depend largely on the number of projects being monitored (single or multiple projects), and the metrics selected for monitoring. For example, reach-scale metrics such as side channel length or area may be easy to census within treatment and control reaches, whereas metrics such as fine sediments in gravels must be sampled at several locations within a reach using a systematic or stratified random sampling design.

\section{Hydrology}

\section{Restoration Actions for Improving Hydrology}

Nearly all streams across the CTUIR ceded lands are water-quality limited for at least one parameter (U.S. Environmental Protection Agency and U.S. Department of Agriculture, 1998), and many stream segments are over appropriated for water withdrawals. Often, the same reaches that are limited for water quality have other stressors like floodplain alterations and riparian deforestation. Changes in water quality and quantity have significant implications for native aquatic organisms. Therefore, the CTUIR implements several types of restoration actions to address water quality and quantity limitations (table 1).

Restoring variation in flow across stream reaches and entire basins is a goal of stream restoration by the CTUIR. Restoration actions targeting water quantity include the purchase or acquisition of water rights, flow enhancements, or environmental flow releases. For example, the purchase of a water right may have basin-wide effects on instream flow conditions and multiple benefits for aquatic habitat and organisms. Given a naturally functional channel form, increased flow provides moderated stream temperatures and a greater diversity of aquatic habitats. Acquisition of flows in chronically over allocated rivers may require strategies for flow protection so that augmented flows remain protected and available to support instream uses.

Water temperature is one of the most widespread impairments to salmon habitat in the Pacific Northwest (http://www.ecy.wa.gov/programs/wq/303d/currentassessmt.html), and is often the target of restoration efforts to improve water quality. Despite substantial restoration effort and research, improving temperature conditions remains a considerable challenge at the watershed and reach scales. Over the past two decades, stream restoration efforts have sought to improve stream temperatures by increasing riparian shade, thereby protecting the stream surface from solar input. Recent research suggests that the processes regulating water temperature are also influenced by valley form and contributions from shallow groundwater (or hyporheic sources) at varying spatial and temporal scales, particularly in alluvial valleys in semi-arid regions (Poole and Berman, 2001; Arrigoni and others, 2008; Hester and others, 2009). 
Table 1. Restoration actions used by the Confederated Tribes of the Umatilla Indian Reservation to address hydrology objectives.

\begin{tabular}{ll}
\hline \multicolumn{1}{c}{ Hydrology restoration objectives } & \multicolumn{1}{c}{ Common restoration actions } \\
\hline $\begin{array}{l}\text { Reconnect surface and ground waters to increase } \\
\text { the diversity of water temperature and diversity }\end{array}$ & $\begin{array}{l}\text { Restoration that creates a more sinuous channel approximating } \\
\text { historical cross section forms }\end{array}$ \\
Decrease maximum stream temperature & $\begin{array}{l}\text { Water right purchase } \\
\text { Reservoir releases } \\
\text { Upstream water management } \\
\text { Riparian plantings }\end{array}$ \\
& $\begin{array}{l}\text { Restoration that creates a more sinuous channel approximating } \\
\text { historical cross section forms }\end{array}$ \\
& $\begin{array}{l}\text { Riparian plantings } \\
\text { Cattle and ungulate exclusion }\end{array}$ \\
& Upstream erosion management \\
Reduce suspended sediment & Restoration that creates a more sinuous channel approximating \\
& historical cross section forms \\
Increase water temperature variability & Restoration that creates a more sinuous channel approximating \\
& historical cross section forms \\
Increase floodplain storage capacity and increase & \\
summer baseflow & Water right purchase \\
Restore streamflow & Reservoir releases \\
& Upstream water management \\
\hline
\end{tabular}

Based on this new understanding, the restoration of surface water/groundwater connectivity may ameliorate extreme water temperatures as well as increase diversity in channel velocities. Frequently, the aim of such stream restoration projects is to create a more variable channel form that redistributes hydraulic gradients and sub-surface flow paths, resulting in a greater diversity in flow path lengths and temperatures. Actions for creating more variable channel forms include channel realignment to regain geometry and planform conditions comparable to historical conditions and the creation of side channels. Approaches to restore processes of natural exchange between the channel network and the hyporheic zone are still emerging and there are few well-documented examples of the outcomes of such efforts in semiarid rivers. 


\section{Hydrologic Monitoring Parameters and Techniques}

Table 2 lists select monitoring methods for restoration projects addressing water quality and quantity. Approaches to water temperature monitoring at the reach scale include the 7-day maximum moving average (Oregon Department of Environmental Quality, 1995) and temperature diversity across all inundated areas of a floodplain (Arscott and others, 2001). The 7-day maximum moving average method is straightforward and produces a metric that is used frequently to compare stream temperature among several streams. The floodplain temperature diversity approach requires additional effort, but produces a more realistic and detailed set of data that capture the range of thermal conditions in floodplain habitats. Also, the 7-day maximum moving average metric can be calculated for a subset of the floodplain temperature diversity points, allowing for production of a more detailed but concise characterization of floodplain waters. Both methods rely on low-cost temperature loggers, which are widely used by local, state, and federal water-quality managers.

Many restoration efforts seek to change the thermal regime of a river reach by altering other physical parameters, such surface water/groundwater exchange, local floodplain storage of water, and average residence time of water in restored sections of river. Over the past decade, Forward Looking InfraRed (FLIR) imagery has emerged as an efficient means of viewing longitudinal temperature profiles, which can be used to assess various thermal influences at spatial scales from reaches to the entire length of a main stem river (Torgersen and others, 1999). Similarly, a snapshot of suspended-sediment measurements is possible by collecting samples (either with an automated unit or manually) throughout a watershed during a variety of hydrologic events. Biggs and others (2002) show that carefully stratifying samples throughout a watershed can help relate suspended-sediment loads with land use and geology. Because suspended-sediment monitoring presents many logistical challenges, such as the timing of sampling with storm events that move material, project leaders may also consider surrogates methods for suspended sediment, such as turbidity sampling (Rasmussen and others, 2009; Jastram and others, 2010; Schenk and Bragg, 2014).

Increasing variability in temperature and velocity is a goal of many stream restoration projects, and project objectives often include increasing local floodplain storage capacity, increasing surface water/groundwater exchange, and direct restoration of flow. Projects that seek to increase local floodplain storage capacity or seek to raise the local water table typically are associated with channel realignment efforts. Direct restoration of channel flow can be monitored with discharge measurements (Dunne and Leopold, 1978). However, relatively small changes in flow may not always be detectable on the restoration project site because larger scale processes can influence the availability of surface flow. Examples of these processes include loss of surface water to the hyporheic zone, gain of surface water at upwelling zones, or changes in groundwater elevation with bed aggradation or incision. The most common way to monitor changes in groundwater elevations before and after a stream restoration project is by installing shallow wells or piezometers and instrumenting them with water pressure transducers (Woessner, 2000). Subtle changes in local floodplain storage may be detectable through various flow metrics extracted from discharge measurements (Olden and Poff, 2003; Grayson and others, 2004). 
Table 2. Restoration objectives, metrics, methods, and references for restoration projects addressing hydrology.

[Abbreviations: ODEQ, Oregon Department of Environmental Quality; USGS, U.S. Geological Survey]

\begin{tabular}{|c|c|c|}
\hline Hydrology restoration objective & Monitoring metric & Monitoring approach \\
\hline \multirow{2}{*}{$\begin{array}{l}\text { Reconnect surface and ground } \\
\text { waters to increase the } \\
\text { diversity of water temperature } \\
\text { and diversity }\end{array}$} & $\begin{array}{l}\text { Diversity of flowpath length } \\
\text { and number }\end{array}$ & Tracer studies (Woessner, 2000) \\
\hline & & $\begin{array}{l}\text { MODFLOW in open channels } \\
\text { (Osman and Bruen, 2002) }\end{array}$ \\
\hline \multirow[t]{2}{*}{$\begin{array}{l}\text { Decrease maximum stream } \\
\text { temperature }\end{array}$} & $\begin{array}{l}\text { Maximum mean weekly } \\
\text { temperature and } \\
\text { temperature diversity }\end{array}$ & $\begin{array}{l}\text { 7-day maximum moving average } \\
\text { (ODEQ, 1995) }\end{array}$ \\
\hline & & $\begin{array}{l}\text { Longitudinal temperature profile } \\
\text { (Torgersen and others, 1999) }\end{array}$ \\
\hline \multirow[t]{2}{*}{ Reduce suspended sediment } & Suspended sediment loads & Biggs and others (2002) \\
\hline & Turbidity as a surrogate & $\begin{array}{l}\text { Rasmussen and others (2009; } \\
\text { Jastram and others (2010); } \\
\text { Schenk and Bragg (2014) }\end{array}$ \\
\hline \multirow[t]{2}{*}{$\begin{array}{l}\text { Increase water temperature } \\
\text { variability }\end{array}$} & $\begin{array}{l}\text { Buffering temperature in main } \\
\text { stem channel }\end{array}$ & $\begin{array}{l}\text { Lagging of temperatures } \\
\quad \text { (Arrigoni and others, 2008) }\end{array}$ \\
\hline & & $\begin{array}{l}\text { Water temperature diversity } \\
\text { (Arscott and others, 2001) }\end{array}$ \\
\hline \multirow{2}{*}{$\begin{array}{l}\text { Increase floodplain storage } \\
\text { capacity and increase summer } \\
\text { baseflow }\end{array}$} & $\begin{array}{l}\text { Water residence time or } \\
\text { transient storage }\end{array}$ & $\begin{array}{l}\text { Shape of breakthrough curve and } \\
\text { slope of tail (Woessner, 2000) }\end{array}$ \\
\hline & & $\begin{array}{l}\text { Vertical hydraulic gradient } \\
\text { (Woessner, 2000) }\end{array}$ \\
\hline \multirow[t]{4}{*}{ Restore streamflow } & $\begin{array}{l}\text { Stream gaging and associated } \\
\text { metrics - the flow exceeded } \\
90 \text { percent of the time, the }\end{array}$ & $\begin{array}{l}\text { Stream gaging (Dunne and } \\
\text { Leopold, 1978) }\end{array}$ \\
\hline & $\begin{array}{l}\text { base flow index, and the } \\
\text { average of the annual } \\
\text { minimum flow divided by } \\
\text { catchment area }\end{array}$ & $\begin{array}{l}\text { Base flow index (Grayson and } \\
\text { others, 2004) }\end{array}$ \\
\hline & & $\begin{array}{l}90 \text { percent flow exceedance and } \\
\text { average minimum flow by } \\
\text { catchment area (Olden and } \\
\text { Poff, 2003) }\end{array}$ \\
\hline & & $\begin{array}{l}\text { USGS gaging protocols (Rantz, } \\
\text { 1982; USGS, 1983) }\end{array}$ \\
\hline
\end{tabular}


Although hydrologic functions occur along a continuum of scale, PHAMS focuses on reach and segment scales (fig. 9) that most often are the focus of stream restoration activities. Increases in surface water/groundwater exchange are a restoration objective that is increasingly associated with restoring a variety of subsurface flow paths through the hyporheic zone. In semiarid rivers, these actions are often done to reduce water temperature, create cool water refugia, and increase hydraulic diversity, such as increase variation in water velocities (Confederated Tribes of the Umatilla Indian Reservation, 2012). These techniques also seek to increase water storage and hyporheic exchange, resulting in buffering of water temperatures (Arrigoni and others, 2008; fig. 10). These efforts to recreate complex and mature three-dimensional forms in the floodplain are new and likely require additional monitoring and a clear experimental design to obtain unambiguous monitoring results.

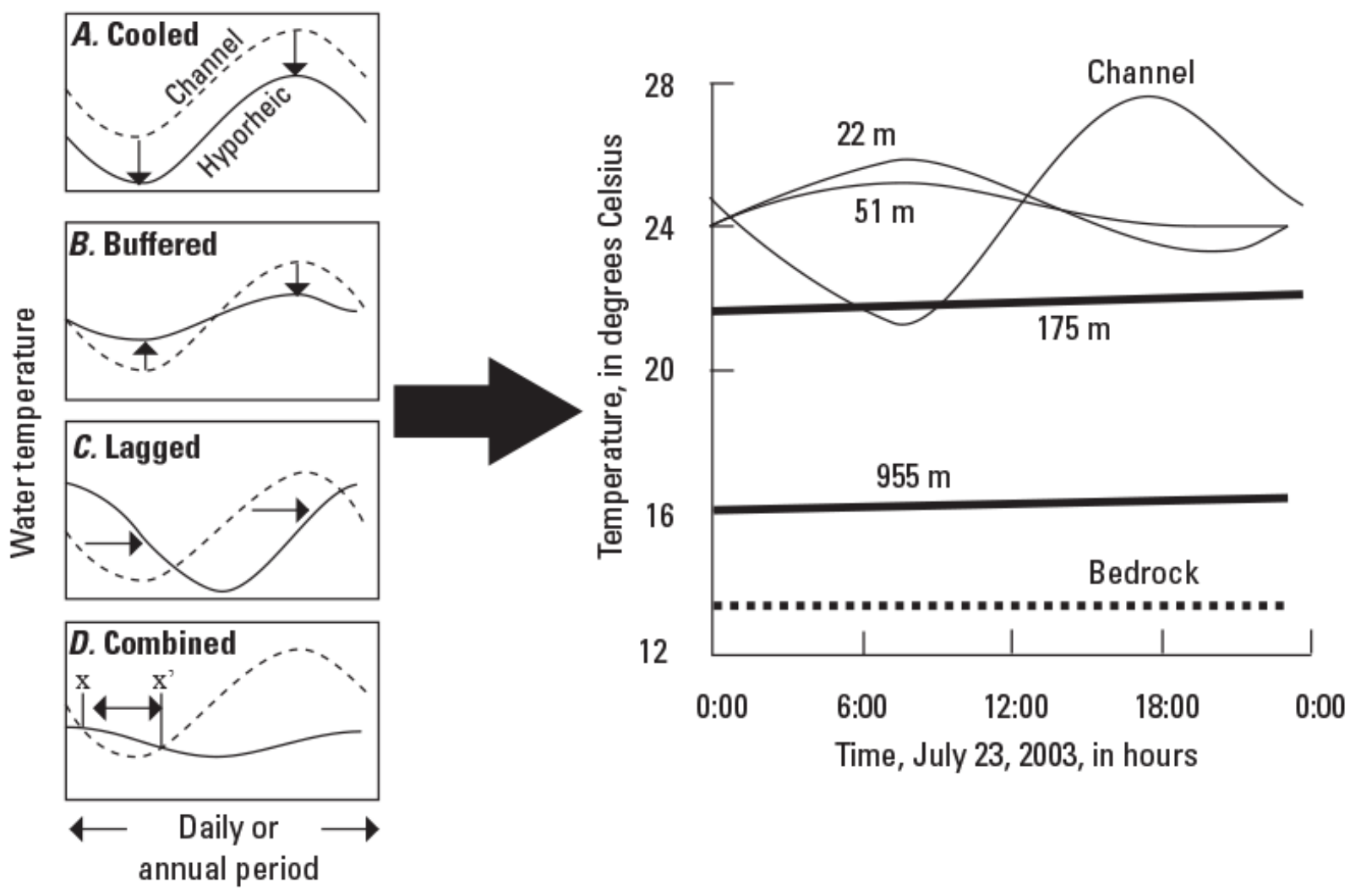

Figure 9. Graphs showing potential influences of hyporheic flow on instream temperatures. The left side of the figure shows metrics for describing differences between temperature cycles that can be combined to describe observed differences. On the right site of the figure, data from the Umatilla River show the diel signal from flow paths with varying lengths (Arrigoni and others, 2008). Graphs from "buffered, lagged, or cooled? Disentangling hyporheic influences" by Arrigoni and others (2008) used with permission from John Wiley and Sons. @ 2008 by the American Geophysical Union. 

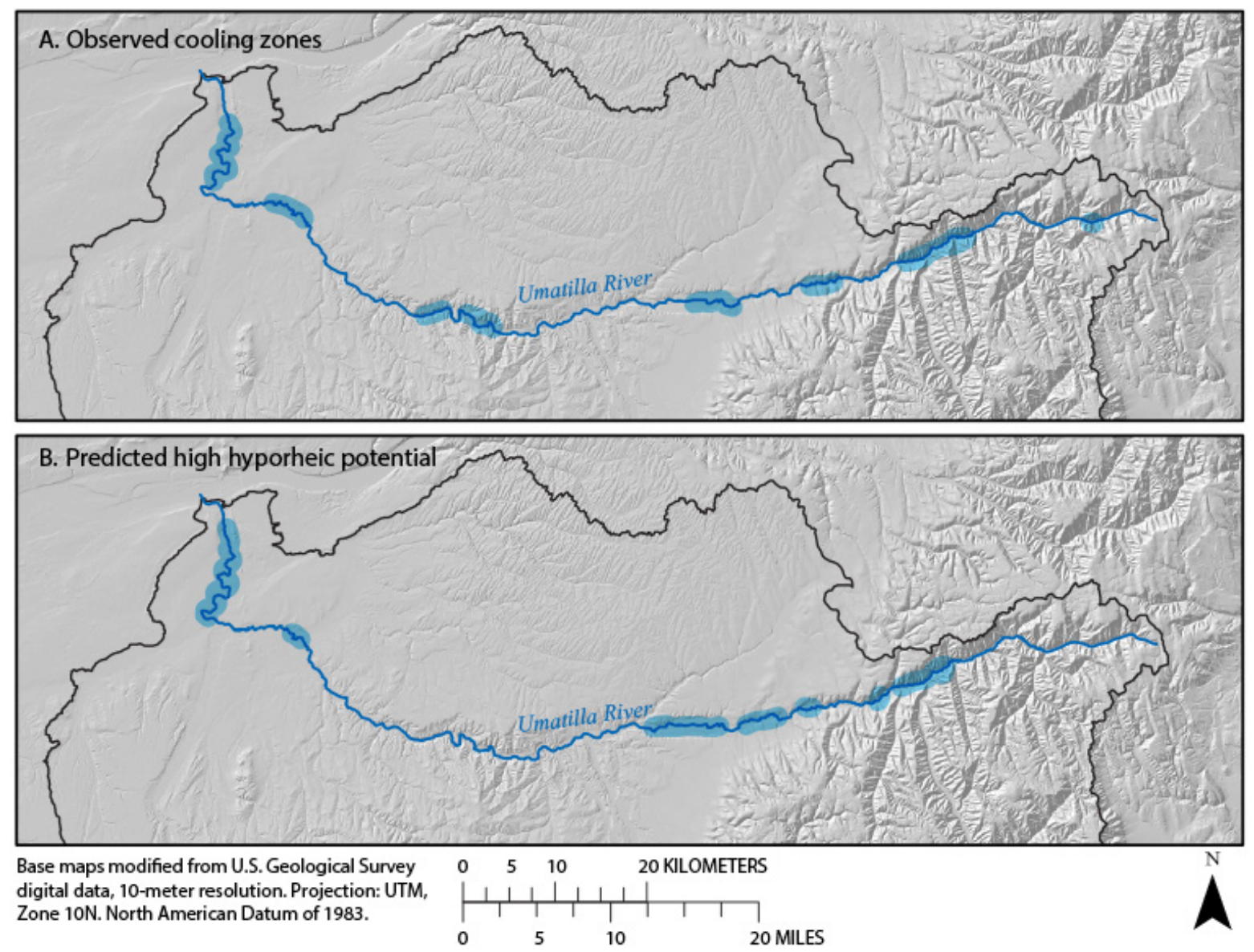

Figure 10. Maps showing observed and predicted zones of cooling and hyporheic potential based in the Umatilla River, Oregon. Hyporheic potential was predicted by O'Daniel (2005) using sinuosity, stream gradient, floodplain width, and valley width derived from 10-meter Digital Elevation Models. Maps adapted from O'Daniel (2005).

\section{Geomorphology}

\section{Restoration Actions for Improving Geomorphology}

Human activities have dramatically altered watershed- and reach-scale geomorphic processes by changing erosion regimes (usually by increasing erosion rates or trapping sediment behind dams), isolating rivers from their floodplains (by reducing peak flows and building dikes and levees), and channelization that sometimes results in channel incision. The CTUIR's restoration efforts focus in part on restoring key geomorphological processes in order to reconnect rivers with their floodplains, reducing erosion and sediment supply to reaches, and to a lesser extent, restoring incised channels.

Restoration actions that affect the geomorphologic features of a reach may include watershed scale actions such as reduction of erosion and sediment supply (like erosion reduction efforts on forest or agricultural lands), reach-scale actions (like floodplain reconnection, channel reconstruction, or creation of habitat features with wood, boulder placement, or other built structures), or efforts to restore sediment retention processes to aggrade an incised channel. To help with the identification of monitoring parameters and techniques for different types of 
restoration action, we group restorations actions into six main categories based on their objectives (table 3 ). The first four objectives are typically addressed by reach-scale actions (which may be a combination of site-scale actions). The last two addressing sediment supply are typically addressed at either the watershed scale or reach scale, depending on whether the actions address upland or riparian erosion processes.

Table 3. Restoration actions used by the Confederated Tribes of the Umatilla Indian Reservation to address geomorphic objectives.

\begin{tabular}{ll}
\hline \multicolumn{1}{c}{ Geomorphology restoration objectives } & \multicolumn{1}{c}{ Common restoration actions } \\
\hline Restore flood plain channels and channel migration & $\begin{array}{l}\text { Levee removal or setback } \\
\text { Rip-rap removal } \\
\text { Construction of side-channels }\end{array}$ \\
Restore channel meanders and cross section form & $\begin{array}{l}\text { Channel re-meandering } \\
\text { Channel reconstruction }\end{array}$ \\
Aggrade an incised channel & $\begin{array}{l}\text { Livestock exclusion } \\
\text { Beaver dam support structures } \\
\text { Grade control additions, such as boulder weirs }\end{array}$ \\
Increase in-channel habitat diversity (structures) & Installation of wood structures \\
& Installation of boulder structures \\
Reduce coarse sediment supply & Forest road rehabilitation \\
& Forest road rehabilitation \\
Alternative tilling practices & Livestock exclusion \\
\hline
\end{tabular}

\section{Geomorphic Monitoring Parameters and Techniques}

Each of the six restoration objectives guides the selection of monitoring parameters and techniques (table 4), but the scales at which parameters are measured is not necessarily the same as the scale of the restoration action. For example, actions that reduce erosion rates in a watershed are implemented at a watershed scale, but their effects may be monitored at reach or site scale. Alternatively, grouping a series of site-scale restoration actions within a single reach might allow monitoring of reach-scale features or reach-scale metrics of site-scale features. For instance, the percentage of pool area can be used to monitor the effectiveness of multiple instream structures at creating this habitat type.

In this section, we describe monitoring metrics and techniques that may be used to measure reach-scale responses to restoration actions. Metrics and methods are grouped into the two main categories: (1) floodplain metrics and (2) in-channel metrics. The floodplain metrics largely correspond to the objectives of reconnecting floodplains or restoring channel meanders, whereas the in-channel metrics largely correspond to the remaining objectives of restoring incised channels, increasing structural complexity, or reducing sediment supply. 
Table 4. Geomorphology monitoring metrics and methods associated with geomorphology restoration objectives.

[Abbreviations: GPS, Global Positioning System; LiDAR, Light Detection and Ranging]

\begin{tabular}{|c|c|c|}
\hline Geomorphology restoration objective & Monitoring metric & Monitoring approach \\
\hline \multicolumn{3}{|l|}{ Floodplain or planform metrics } \\
\hline \multirow[t]{7}{*}{$\begin{array}{l}\text { Restore flood plain channels and } \\
\text { channel migration }\end{array}$} & Percentage of floodplain disconnected & $\begin{array}{l}\text { Measure percentage of floodplain area disconnected } \\
\text { from the main channel from aerial photography and } \\
\text { field data }\end{array}$ \\
\hline & $\begin{array}{l}\text { Percentage of floodplain connected at } \\
\text { different magnitude flows } \\
\text { (bankfull, 5-year, and 10-year } \\
\text { flows) }\end{array}$ & $\begin{array}{l}\text { Measure percentage of floodplain area connected to } \\
\text { the main channel from aerial photography and field } \\
\text { data and HEC-RAS inundation mapping }\end{array}$ \\
\hline & Braid-channel ratio (Lsc/Lmain) ${ }^{1}$ & $\begin{array}{l}\text { Measure lengths of widest channel and side channels } \\
\text { from aerial photography (Friend and Sinha, 1993) }\end{array}$ \\
\hline & $\begin{array}{l}\text { Node density or channel complexity } \\
\text { index }\end{array}$ & $\begin{array}{l}\text { Number of nodes per length of channel (Luck and } \\
\text { others, 2010), or sinuosity times the number of } \\
\text { nodes (Brown, 2002) }\end{array}$ \\
\hline & Channel migration rate & $\begin{array}{l}\text { Measure channel migration from multiple sequential } \\
\text { aerial photographs (Latterell and others, 2006) }\end{array}$ \\
\hline & Bank erosion rate & $\begin{array}{l}\text { Where erosion rates are relatively low, bank pins can } \\
\text { be used to monitor the erosion rate (Bull, 1997) }\end{array}$ \\
\hline & $\begin{array}{l}\text { Turnover rate of flood-plain surfaces, } \\
\text { half-life of flood-plain surfaces }\end{array}$ & $\begin{array}{l}\text { Measure age distribution of floodplain surfaces from } \\
\text { aerial photography (Beechie and others, 2006; } \\
\text { Latterell and others, 2006) }\end{array}$ \\
\hline Restore channel meanders & Sinuosity $\left(\mathrm{L}_{\mathrm{c}} / \mathrm{L}_{\mathrm{v}}\right)^{2}$ & $\begin{array}{l}\text { Measure sinuosity from aerial photography (Leopold } \\
\text { and Wolman, 1957) }\end{array}$ \\
\hline \multicolumn{3}{|l|}{ In-channel metrics } \\
\hline \multirow[t]{2}{*}{ Aggrade an incised channel } & $\begin{array}{l}\text { Entrenchment ratio or confinement } \\
\quad \text { ratio }\left(\mathrm{W}_{\mathrm{fp}} / \mathrm{W}_{\mathrm{bf}}\right)^{3}\end{array}$ & $\begin{array}{l}\text { Measure width of floodplain and bankfull channel in } \\
\text { the field or from aerial photography (Rosgen, 1994; } \\
\text { Beechie and others, 2006) }\end{array}$ \\
\hline & Aggradation rate & $\begin{array}{l}\text { Measure channel aggradation with repeat cross section } \\
\text { surveys, GPS surveys, or LiDAR surveys (Wheaton } \\
\text { and others, 2010a,b), or with sediment deposition } \\
\text { plates (Kleiss, 1996; Heimann and Roell, 2000) }\end{array}$ \\
\hline Restore channel cross section & $\begin{array}{l}\text { Channel geometry (bankfull width, } \\
\text { bankfull depth, width/depth ratio) }\end{array}$ & $\begin{array}{l}\text { Measure channel geometry with field-surveyed cross } \\
\text { sections or from bathymetric LIDAR (Leopold and } \\
\text { others, 1964; McKean and others, 2009) }\end{array}$ \\
\hline
\end{tabular}




\begin{tabular}{|c|c|c|}
\hline Geomorphology restoration objective & Monitoring metric & Monitoring approach \\
\hline \multirow[t]{5}{*}{$\begin{array}{l}\text { Increase in-channel habitat diversity } \\
\text { (structures) }\end{array}$} & Wood counts & $\begin{array}{l}\text { Counts of total wood above threshold size or by size } \\
\text { class (Montgomery and others, 1995; Beechie and } \\
\text { Sibley, 1997) }\end{array}$ \\
\hline & Pool frequency or spacing & $\begin{array}{l}\text { Count of number of pools per channel length or } \\
\text { spacing between pools (Montgomery and others, } \\
\text { 1995; Beechie and Sibley, 1997) }\end{array}$ \\
\hline & Percent pool area & $\begin{array}{l}\text { Percentage of wetted area classified as pools (Beechie } \\
\text { and Sibley, 1997) }\end{array}$ \\
\hline & Residual pool depth (dmax/dtail) ${ }^{4}$ & $\begin{array}{l}\text { Measurement of maximum pool depth minus the tail } \\
\text { crest depth (Lisle, 1987) }\end{array}$ \\
\hline & Residual pool depth (dmax/dtail) & $\begin{array}{l}\text { Measurement of maximum pool depth minus the tail } \\
\text { crest depth (Lisle, 1987) }\end{array}$ \\
\hline \multirow[t]{4}{*}{ Reduce coarse sediment supply } & $\begin{array}{r}\text { Ratio of surface particle size to } \\
\text { subsurface particle size }\left(D^{*}\right)\end{array}$ & $\begin{array}{l}\text { Comparison of the median grain size }\left(\mathrm{D}_{50}\right) \text { from } \\
\text { pebble counts of surface and subsurface grain sizes } \\
\text { (Lisle and Madej, 1992) }\end{array}$ \\
\hline & Armoring ratio & $\begin{array}{l}\text { Comparison of the median grain size }\left(\mathrm{D}_{50}\right) \text { from a } \\
\text { pebble count of surface particles and sieved bulk } \\
\text { sample of subsurface particles (Bunte and Abt, } \\
\text { 2001) }\end{array}$ \\
\hline & $\begin{array}{l}\text { Ratio of sediment supply to transport } \\
\text { capacity }\left(Q^{*}\right)\end{array}$ & $\begin{array}{l}\text { Sieving of surface and subsurface bed material } \\
\text { samples to calculate Q* (Dietrich and others, 1989) }\end{array}$ \\
\hline & Facies mapping & $\begin{array}{l}\text { Map spatial distributions of median grain sizes }\left(D_{50}\right) \\
\text { (Buffington and Montgomery, 1999) }\end{array}$ \\
\hline \multirow[t]{2}{*}{ Reduce fine sediment supply } & $\begin{array}{l}\mathrm{V}^{*} \text { (fine sediment volume divided by } \\
\text { residual pool volume) }\end{array}$ & $\begin{array}{l}\text { Measurement of fine sediment volume in pool divided } \\
\text { by measurement of residual pool depth (Lisle, 1987) }\end{array}$ \\
\hline & $\begin{array}{l}\text { Fine sediment percentage in bed } \\
\text { material }\end{array}$ & $\begin{array}{l}\text { Measurement of fine sediment proportion in bed } \\
\text { material by sieving of bulk samples (McNeil and } \\
\text { Ahnell, 1964; Grost and others, 1991) }\end{array}$ \\
\hline
\end{tabular}

${ }^{1} \mathrm{Lsc} / \mathrm{Lmain}$ is the total length of side channels relative to the total length of the main channel.

${ }^{2} \mathrm{Lc} / \mathrm{Lv}$ is the channel thalweg length divided by the valley centerline length, approximately channel sinuosity.

${ }^{3} \mathrm{Wfp} / \mathrm{Wbf}$ is the width of the floodplain relative to the width of the bankfull channel.

${ }^{4}$ dmax-dtail is the maximum depth of the pool minus the tail-crest depth, approximating residual pool depth.

\section{Floodplain or Planform Metrics}

The effectiveness of restoration actions that aim to reconnect a river to its floodplain can be monitored with metrics of both condition and processes. Perhaps the most obvious metric for measuring restoration success or continued effect is floodplain connectivity. This metric is simply the area of floodplain separated from the channel by revetments or levees divided by the area of natural floodplain. Important requirements of this metric that will make it useful as a monitoring parameter are that the natural floodplain boundary be consistently defined and mapped among reaches, such as by the Federal Emergency Management Agency (FEMA) 100year floodplain, and that there are consistent rules for determining whether portions of that 
floodplain are fully or partially isolated from the river by built structures (including levees, revetments, railroad grades, and road fill). Other relatively simple metrics of floodplain condition and connectivity are channel pattern classification and the quantitative metrics of sinuosity and the braid-channel ratio or node density. Channel pattern may be difficult to use as a monitoring parameter because it can only detect very large changes in channel and floodplain condition. That is, channel pattern is a relatively coarse classification, and only the most dramatic shifts in channel morphology (such as a shift from meandering to braided) can be detected through classification. By contrast, changes in the number or length of side-channels (sometimes referred to as braids) can be monitored using the braid-channel ratio and node density, both of which are easily measured from aerial photography. The braid-channel ratio is the length of all side channels (braids) divided by the length of the main channel (channel) (Lsc/Lmain; Friend and Sinha, 1993; Beechie and others, 2006). Node density is the total number of channel junctions within a specified channel length (such as nodes per km of channel; Luck and others, 2010) or a more complex metric such as the river complexity index, or channel sinuosity multiplied by node density (Brown, 2002).

Metrics directly related to channel-floodplain dynamics include channel migration rate, floodplain turnover rate, and floodplain age structure. Channel migration rate is measured from sequential aerial photographs, and quantifies lateral channel movement from year to year (usually in meters/year) (O'Connor and others, 2003). Changes in channel migration rate can indicate either increase in disturbance and unusually high migration rates (such as from an increase in sediment supply) or decreased migration rates where channel migration has been restricted by rip-rap or levees. Where bank erosion rates are too low to measure from aerial photography, bank pins can be installed to measure rates of bank erosion (Bull, 1997). Floodplain age structure is simply the distribution of floodplain ages by area, and indicates whether the channel migrates and restructures the floodplain as expected under natural conditions for a given channel pattern. Floodplain age structure is also measured from aerial photography, although ground truthing to associate the correct tree species and ages with patches delineated on aerial photography is required. Floodplain turnover rate has been estimated from lateral migration rates, tracking patch erosion in sequential aerial photographs, or calculated from floodplain age structure at a single point in time. Turnover rate estimated from lateral migration rate is simply the floodplain width divided by the migration rate, which gives the number of years it would take for the channel to move across the entire floodplain. The patch half-life (the time required for one-half of the existing patches to be eroded), can be estimated by overlaying grid points on an aerial photograph and calculating the number of points that are eroded in subsequent photographs in the time series (Latterell and others, 2006). Estimating turnover from age structure uses the cumulative age distribution to estimate the probability (p) that any patch will be eroded in any 1 year, and $1 / p$ is the average return interval for erosion of a floodplain patch (Beechie and others, 2006).

For restoration actions that aim to restore sinuosity of single thread channels, sinuosity can be directly measured from aerial photography. Sinuosity is the channel thalweg length divided by the valley centerline length $(\mathrm{Lc} / \mathrm{Lv})$, and measurements from aerial photographs should be accurate enough to detect relatively small changes in the degree of meandering (Leopold and Wolman, 1957). Changes in sinuosity can occur without a change in channel pattern. Channel re-meandering efforts may also aim to restore natural channel geometry. Channel geometry refers to the cross-section dimensions of a stream channel, typically characterized by bankfull channel width, average bankfull channel depth, and the width to depth 
ratio. These metrics can be summarized at the scale of the entire reach to detect whether the channel has either incised or aggraded. Incising channels typically get both narrower and deeper with reduced width:depth ratio, and aggrading channels typically get wider and shallower with an increased width:depth ratio. However, incised channels eventually widen and aggrade, so some incised channels eventually may become wide and shallow. Where channel geometry is stable over time, the channel shape also may be an indicator of whether relative sediment supply is high or low, or whether sediment supply is dominated by suspended load or bed load. Cross sections for incised channels might include both the incised channel dimensions and the bankfull (inset) channel dimensions to indicate the magnitude of incision relative to the 'normative' channel dimensions for a reach (Beechie and others, 2008).

\section{Instream Metrics}

Restoring incised channels is designed to restore both vertical and lateral connectivity, and monitoring metrics include aggradation rates, elevation of the water table, ground-truthing of floodplain inundation, and the entrenchment ratio. The entrenchment ratio is the most direct measure of lateral connectivity, as it compares floodplain width to bankfull channel width (Rosgen, 1994; Beechie and others, 2008). Field verification of floodplain inundation during floods can be used to confirm that restoration actions result in increased lateral connectivity. Elevation of the water table is another measure that documents changes in water table elevation after restoration actions initiate channel aggradation. This metric indicates whether aggrading the incised channel has the anticipated effect on water table elevation and ultimately, availability of water for riparian vegetation (Pollock and others, 2012). Finally, the rate of aggradation can be measured with repeat topographic surveys to document that the elevations of the channel bed and inset floodplain are responding as expected after restoration (Pollock and others, 2007; Wheaton and others, 2010a). Deposition plates can also be used to monitor aggradation rates on floodplain surfaces.

For restoration efforts that aim to increase structural complexity of habitats, wood counts, pool frequency, residual depth, and pool area are common metrics of habitat structure in streams and rivers. Pool frequency is simply the number of pools per length of channel (such as pools per $100 \mathrm{~m}$ ), which can be normalized to the size of the channel by expressing pool spacing (the distance between pools) as pools per channel width:

$$
\text { pools per channel width }=\frac{\# \text { pools }}{\text { reach length/bankfull width }}
$$

Pool frequency tends to increase with decreasing channel slope (for channels with gradient less than about 4 or 5 percent) and with increasing abundance of wood (Montgomery and others, 1995; Beechie and Sibley, 1997). In channels with high wood abundance (greater than 0.4 pieces per meter), pool spacing is typically around 1 channel-width between pools. However, in steeper channels, pool spacing tends to be controlled by cross-channel lines of boulders forming step pools at a spacing of about 2 channel-widths per pool, and the effect of wood abundance is poorly known. Wood counts are commonly tallied as the total number of pieces above some threshold size (such as greater than $10 \mathrm{~cm}$ diameter and $1 \mathrm{~m}$ length), or as the total number of pieces in several size classes (Montgomery and others, 1995; Beechie and Sibley, 1997).

Pool area is simply the area of pools in a reach, and percent pool is the area of pools divided by the total wetted area of the reach. Percent pool tends to be higher in low gradient channels and percent pool typically decreases with increasing stream gradient. Percent pool 
also can be increased by increased wood abundance in moderate gradient channels (between about 1 and 4 percent), but wood abundance does not appear to increase pool area in low- or high-gradient channels (Beechie and Sibley, 1997). Residual pool depth is the maximum depth of the pool minus the tail-crest depth (dmax-dtail), which can be considered the depth of the pool when the flow goes to zero (Lisle, 1987). This metric for pool depth has the advantage of being independent of stream flow, meaning the stream flow at the time of the survey does not influence the monitoring parameter.

Grain size or the amount of coarse and fine sediment may be a useful indicator of reachscale conditions in some cases, although both are measured at specific sites within reaches. Trends in bed grain size measured by pebble counts may be discernible when changes in grain size are large, but high spatial variation in grain sizes may make detection of changes difficult. The most effective strategy to reduce variation and increase the ability to detect change is to select a common location for all pebble counts, such as a riffle crest or apex of a point bar (Kloehn and others, 2008). For example, measuring grain size consistently at riffle crests within a reach will reduce variation in grain sizes among pebble count sites and increase the likelihood of measuring grain size at the same or similar sites from year to year. GPS locations of pebble counts may be somewhat useful in relocating sites, but it is more important to measure grain size at the same geomorphic location than at the same geographic location. That is, if riffle crest locations move from year to year, then pebble counts should be conducted at new riffle locations.

Ratios of surface to subsurface grain sizes can also be used to characterize trends in sediment supply, as these metrics reflect sediment supply relative to transport capacity. Channels with armored beds have low sediment supply relative to transport capacity, and channels with unarmored beds have high sediment supply relative to transport capacity. The three metrics available for measuring armoring ratios are $\mathrm{D}^{*}$, the 'armoring ratio,' and $\mathrm{Q}^{*}$. From a sampling perspective, the most straightforward metrics compare the $\mathrm{D}_{50}$ (or median grain size) of the surface material to the $\mathrm{D}_{50}$ of the subsurface material. This can be captured by two metrics - the $D^{*}$ and armoring ratio. D* uses a pebble count of the surface material and a pebble count of the sub-surface material (Lisle and Madej, 1992). The armoring ratio uses a pebble count of the surface material and a sieved bulk sample of the sub-surface (Bunte and Abt, 2001). The armoring ratio has been used extensively in western Oregon to describe bar armoring (O'Connor and others, 2014). In contrast to the $\mathrm{D}^{*}$ and armoring ratio, the $\mathrm{Q}^{*}$ metric is the most timeconsuming to measure, as it requires sieving bulk samples of the surface and sub-surface grains sizes, but also calculating and interpreting what that ratio signifies for sediment discharge relative to transport capacity (Dietrich and others, 1989). The $\mathrm{Q}^{*}$ metric, although theoretically sound, generally is not used in monitoring because estimating sediment transport capacity is challenging at best.

\section{Connectivity}

\section{Restoration Actions for Improving Connectivity}

The most obvious restoration actions for enhancing passage (or longitudinal connectivity) entail the modification, removal, or replacement of barriers. Addressing issues created by a manmade barrier or structure typically requires less change to land management strategies and produces greater benefits to a fish population with less cost. Actions such as reducing water withdrawals are conceptually simple but may be more challenging to implement because of 
direct costs to other water users. Legacy effects such as channel modification from historical hard rock or placer mining also may be difficult to address, but are important considerations when planning restoration actions.

Where flow or temperature barriers are caused indirectly by land-use practices, restoration actions may need to address such processes as channel incision, increased sediment supply and channel aggradation, or loss of riparian shade. That is, when considering a reachscale restoration action, one should consider whether the current channel form and dynamics deviate significantly from their natural potential, and whether watershed conditions can be altered to put the channel on a trajectory towards its natural form and dynamics. If watershedscale problems cannot be corrected, then the effectiveness of reach-scale restoration actions may be reduced. For example, if a thermal barrier is partly created by excessive sediment loading from upstream sources (which creates a wider and shallower channel), then likely effectiveness of watershed-wide efforts to address sediment must be considered when planning, permitting, and implementing a reach-scale action such as riparian restoration. If the watershed scale problem cannot be effectively addressed, then the reach-scale restoration effort should be modified or perhaps delayed until upstream problems can be effectively addressed. That is, management and restoration actions should reconcile and address processes and interactions across multiple scales (Amoros and Bornette, 2002).

Considerations for effective restoration of connectivity include:

- Identify high value habitat and barriers preventing access to that habitat.

- Improve hydrologic connectivity to support community and ecosystem dynamics (Larned and others, 2010).

- Improve the condition of, and access to, off-channel habitats.

- Improve the hyporheic and groundwater influence on stream channels and networks to the extent possible.

- Develop conservation easements to limit disturbance of in-stream, riparian, and floodplain areas.

- Exclude cattle from the stream channel to reduce habitat disturbance and decrease bank trampling.

- Understand habitat requirements for species of concern (Bisson and others, 1988).

- Design channels with morphology and dynamics suitable to their geomorphic setting to complement passage along the stream network and within and between spatially distinct habitats.

\section{Connectivity Monitoring Parameters and Techniques}

Unlike other touchstones, Longitudinal Connectivity does not have a direct measure; rather, the qualities of specific features that inhibit or promote longitudinal connectivity are generally identified and quantified. Therefore, connectivity can be inferred from data identifying presence or absence of geomorphic, hydrologic, or biological features in specific habitats or locations. For example, connectivity between a channel and its floodplain is related in part by the presence of key riparian or aquatic species in floodplain habitats. Similarly, upstreamdownstream connectivity can be inferred from the presence/absence or abundance of migratory fishes upstream of potential barriers. Objectives, metrics, and references are in table 5. 
Table 5. Connectivity monitoring metrics and methods associated with connectivity restoration objectives.

[Abbreviations: ODFW, Oregon Department of Fish and Wildlife; USDA, U.S. Department of Agriculture; WDFW, Washington Department of Fish and Wildlife; NMFS, National Marine Fisheries Service; Corps, Corps of Engineers; BOR, Bureau of Reclamation; USGS, U.S. Geological Survey]

\begin{tabular}{|c|c|c|}
\hline Connectivity restoration objective & Monitoring metric & Monitoring approach \\
\hline \multirow[t]{3}{*}{$\begin{array}{l}\text { Increase adult salmon passage between } \\
\text { and within habitats }\end{array}$} & $\begin{array}{l}\text { Presence/absence, number } \\
\text { present }\end{array}$ & $\begin{array}{l}\text { Spawning and carcass surveys (Johnson and } \\
\text { others, 2007; Thurow, 1994; White and } \\
\text { others, 2011) }\end{array}$ \\
\hline & Statutes related to passage & State statutes (ODFW, 2006, 2009) \\
\hline & $\begin{array}{l}\text { Quality of structural barrier } \\
\text { or habitat limiting passage }\end{array}$ & $\begin{array}{l}\text { Assessments, design, and modeling tools } \\
\text { (USDA, 2005; WDFW, 2009; NMFS, } \\
\text { 2011; USDA, 2006; Corps, 2010; BOR, } \\
\text { 2012) }\end{array}$ \\
\hline \multirow[t]{3}{*}{$\begin{array}{l}\text { Improve juvenile salmon passage between } \\
\text { and within habitats }\end{array}$} & $\begin{array}{l}\text { Presence/absence, number } \\
\text { present, species } \\
\text { composition }\end{array}$ & $\begin{array}{l}\text { Electroshocking, kick seines, and snorkeling } \\
\text { surveys (Johnson and others, 2007; } \\
\text { Thurow, 1994; White and others, 2011) }\end{array}$ \\
\hline & Statutes related to passage & State statutes (ODFW, 2006 2009) \\
\hline & $\begin{array}{l}\text { Quality of structural barrier } \\
\text { or habitat limiting passage }\end{array}$ & $\begin{array}{l}\text { Assessments, design, and modeling tools } \\
\text { (USDA, 2005; WDFW, 2009; NMFS, } \\
\text { 2011; USDA, 2006; Corps, 2010; BOR, } \\
\text { 2012) }\end{array}$ \\
\hline $\begin{array}{l}\text { Improve aquatic invertebrate, crayfish, and } \\
\text { amphibian density or composition }\end{array}$ & $\begin{array}{l}\text { Presence/absence, number } \\
\text { present, species } \\
\text { composition }\end{array}$ & $\begin{array}{l}\text { Kick nets, dip net, and Hess sampler } \\
\text { (Barbour and others, 1999) }\end{array}$ \\
\hline \multirow[t]{3}{*}{ Related to Other Touchstones } & Hydrology & $\begin{array}{l}\text { See Hydrology Touchstone Chapter (Corps, } \\
\text { 2010; BOR, 2012; USGS, 2013; } \\
\text { Goovaerts, 1997; Madej and others, 2006; } \\
\text { Torgersen and others, 1999) }\end{array}$ \\
\hline & Geomorphology & $\begin{array}{l}\text { See Geomorphology Touchstone Chapter } \\
\text { (Corps, 2010; BOR, 2012; USGS, 2013; } \\
\text { Goovaerts, 1997; Madej and others, 2006; } \\
\text { Torgersen and others, 1999; Reid and } \\
\text { Dunne, 1996) }\end{array}$ \\
\hline & Riparian Vegetation & See Riparian Vegetation Touchstone Chapter \\
\hline
\end{tabular}

Methods for determining fish species presence or absence range from simple single pass, electrofishing surveys to more intensive mark and recapture studies. The scale at which restoration project design and implementation occur define appropriate methods for ascertaining a response in longitudinal connectivity. Survey methods to identify fish species presence at the reach- and site-scales include kick seines, electrofishing, snorkeling, and spawning surveys (Thurow, 1994; Johnson and others, 2007; White and others, 2011). Survey timing and method must consider life history attributes of a specific species such as run timing, preferred physical habitat for a life stage, and behavior (Everest and Chapman, 1972; Bisson and others, 1988; Bjornn and Reiser, 1991). For instance, snorkel surveys may be most effective outside of 
migration periods and during late morning through mid-day or at night, whereas electrofishing must consider factors such as channel size and complexity and water conductivity.

Determining whether a specific structure, such as a culvert, meets fish passage criteria requires the use of guidelines provided by Oregon Department of Fish and Wildlife's Administrative Rules (Oregon Department of Fish and Wildlife, 2006, 2009), assessment, and inventory guidelines such as U.S. Department of Agriculture (2005) and Washington Department of Fish and Wildlife (2009), or design protocols such as National Marine Fisheries Service (2011). Habitat biologists can effectively combine stepwise guidance with modeling programs such as FishXing (U.S. Department of Agriculture, 2006), HEC RAS (U.S. Army Corps of Engineers, 2010), and SRH-2D (Bureau of Reclamation, 2012) to identify conditions created by a structure and compare them against species-specific capabilities such as burst and sustained speeds.

Where restricted passage results indirectly from land uses, monitoring metrics may include those identified in other touchstone chapters, as well as species-specific habitat requirements. Models such as HEC RAS and SRH 2D are also useful for understanding channel form and hydraulics, and consequently their influence on fish passage. In short, site specific conditions may explain limiting factors such as a lack of dynamic habitat stability, poor habitat complexity issues related to sediment routing, or compromised water quality directly influencing passage to and through a specific reach. Supplemental efforts to refine an understanding of limiting factors and broader scale processes within and adjacent to a reach may also include the use of thermistors to understand water quality, groundwater models such as MODFLOW (U.S. Geological Survey, 2013), in conjunction with piezometer networks and water-surface elevation data, or geostatistical methods (Goovaerts, 1997) tied to spawner or snorkel surveys. Additionally, sediment budgets (Reid and Dunne, 1996), forward-looking infrared radar remote sensing methods (Torgersen and others, 1999; Madej and others, 2006), LIDAR, aerial imagery, or remote sensing methods can supplement ground survey data, design efforts, and monitoring efforts. Collected data and model results also form a basis for justifying actions to funders and permitting entities.

\section{Riparian Vegetation}

\section{Restoration Actions for Improving Native Riparian Vegetation}

Since European American settlement, the distribution and abundance of native riparian vegetation has been affected by many changes, such as fire suppression, channelization, levee and revetment construction, road and rail construction, livestock grazing, flow reductions, logging, mining, agriculture, groundwater withdrawals, and introductions of invasive species. Within the alluvial valleys, CTUIR's objectives for restoring riparian vegetation are to increase riparian function of site-appropriate native vegetation and to reduce and (or) remove invasive species. Common restoration actions to meet both objectives include conservation easements, cattle and ungulate exclusion, removal of introduced species, reintroduction of geomorphic processes, and removal of levees and other barriers to lateral connectivity. The CTUIR also installs large wood structures for short-term benefits associated with riparian vegetation like bank and channel stability, hydrologic controls, and habitat complexity. Because hydrology, geomorphology, and biological communities are important influences on native riparian vegetation, native riparian vegetation may also benefit from process-based restoration projects that: 
- Increase surface and ground water exchange and result in a shallower water table (Loheide and others, 2009).

- Reduce bank heights, incision, and cross-sectional area (Micheli and Kirchner, 2002a).

- Increase the diversity of geomorphic features that influence patterns of surface and subsurface water delivery to riparian areas (Loheide and others, 2009) and provide a range of vegetation habitats.

- Restore beaver populations or increase the stability of their dams because their dams can trap sediment, causing channel aggradation, shallower water tables, increases in hyporheic flow that may influence temperature dynamics, and suitable habitat creation for mesic vegetation (Wright and others, 2002; Pollock and others, 2007; Poole and others, 2008; Pollock and others, 2012).

\section{Riparian Vegetation Monitoring Parameters and Techniques}

At the site and reach scales, measuring the outcomes of riparian restoration typically involves collecting field data on cover, density, size, and rate of recruitment for plant species. Measurements can be made within plots along transects (Hammersmark and others, 2010; Archer and others, 2012) or at targeted locations, such as near monitoring wells (Cooper and others, 2006; Dwire and others, 2006; Loheide and Gorelick, 2007). Similarly, documenting changes in invasive, noxious, or other site-inappropriate species can occur within the same plots. Other considerations when monitoring riparian vegetation following restoration include:

- Because vegetation typically varies laterally away from a stream, collecting data from the water's edge to the upslope would help capture the range in vegetation. See Dent (2004) for additional discussion of plot designs and layouts for vegetation monitoring.

- Plots with clearly established locations enable measurements to be taken from exactly the same location each year and the evaluation of trends in recruitment and species over time (Clarke, 2004; Archer and others, 2012).

- Where possible, Archer and others (2012) recommend collecting data at the species level so that datasets are comprehensive and useful for assessing trends over time and documenting project success.

- Measuring herbaceous vegetation height (or stubble height) may be useful for assessing livestock impacts on riparian vegetation (Dent, 2004).

- Tree canopy height and live crown ratio (an indicator of tree vigor) can be estimated in the field using a clinometer and rangefinder (Dent, 2004).

- Canopy cover can be measured in the field (Columbia Habitat Monitoring Program, 2012) or using Geographic Information Systems (GIS) methods (below).

- Photograph points taken over time over to document qualitative large-scale changes in riparian vegetation (Columbia Habitat Monitoring Program, 2012). More quantitative methods may be needed to document trends in plants species, like newly arriving introduced species. 
Some GIS methods may be appropriate for assessing vegetation changes pre and post restoration at the reach or larger spatial scales. Options include:

- Comparison of vegetation cover before and after restoration using spatial data sources such as aerial photographs (Micheli and Kirchner, 2002a), Quickbird imagery (Johansen and others, 2007), LiDAR (Johansen and others, 2010a; Johansen and others, 2010b), and a combination of Quickbird imagery and LiDAR (Arroyo and others, 2010). Of these, LiDAR may be the most cost effective method for covering large areas for riparian vegetation (Johansen and others, 2010a) as well as other touchstones.

- Identifying mesic and xeric communities from Color infrared (CIR) photographs. Mesic vegetation reflects more near infrared electromagnetic radiation than xeric vegetation (Loheide and others, 2009). GIS results, then, can be verified against field-based vegetation data.

- Evapotranspiration mapping using Forward Looking Infrared, or FLIR, images (Loheide and Gorelick, 2005). Higher evapotranspiration values are indicative of wet meadows.

- Canopy cover - as indicated by overhanging vegetation — can be measured using GIS and LiDAR (Johansen and others, 2010a; Johansen and others, 2010b). Considerations for using GIS techniques include:

- Spatial data with resolution less than $5 \times 5 \mathrm{~m}$ are recommended for assessing changes in riparian vegetation (Goetz, 2006). This means that Landsat and National Land Cover Data datasets (where pixels are $30 \times 30 \mathrm{~m}$ ) are not suited for measuring riparian vegetation changes. Higher resolution datasets that are suitable for measuring riparian vegetation changes include Quickbird, LiDAR, and some aerial photographs.

- Higher-resolution datasets often require processing to identify objects of interest. This process can be time consuming and requires some expertise in object based analysis techniques (Johansen and others, 2011).

- See Clarke (2004) and Pollock and others (2005) for more information on GIS-related methods for riparian monitoring.

- The U.S. Geological Survey has some satellite and aerial photographs available online (http://glovis.usgs.gov/QuickStart.shtml).

\section{Monitoring Planting Success at the Reach Sale}

Table 6 lists some common metrics for monitoring planting success. Dent (2004) provides an overview of collecting data on riparian plantings post restoration. Level II monitoring includes collecting detailed information in order to evaluate restoration success. Typically, data on tree or shrub species, tree or shrub height, dead trees and shrubs, shrub stem class, grass and brush competition, landform type, and animal damage are recorded using consistent species codes. If the number of plantings is small, then the condition of all trees can be observed. Otherwise, observations of planting health can be made for a subset of select trees or within random or strategic plots (typically from 50 to $200 \mathrm{~m}^{2}$ ). 
Table 6. Restoration objectives, metrics, methods, and references associated with riparian vegetation restoration objectives.

[Abbreviations: GIS, Geospatial Information Systems; LiDAR, Light Detection And Ranging; CIR, Color Infrared Photographs]

\begin{tabular}{|c|c|c|}
\hline $\begin{array}{l}\text { Riparian vegetation } \\
\text { restoration objective }\end{array}$ & Monitoring metric & Monitoring approach \\
\hline \multirow[t]{5}{*}{$\begin{array}{l}\text { Increase riparian function } \\
\text { of site-appropriate } \\
\text { native vegetation }\end{array}$} & $\begin{array}{l}\text { Size, density, cover, and age or seral } \\
\text { classes of native or site appropriate } \\
\text { species and rate of recruitment by } \\
\text { native and site appropriate species }\end{array}$ & $\begin{array}{l}\text { Plots along transects (Dent, 2004; } \\
\text { Hammersmark and others, 2010; Archer and } \\
\text { others, 2012) }\end{array}$ \\
\hline & & $\begin{array}{l}\text { Plots near specific locations like wells (Cooper } \\
\text { and others, 2006; Dwire and others, 2006; } \\
\text { Loheide and Gorelick, 2007) }\end{array}$ \\
\hline & & $\begin{array}{l}\text { GIS techniques (Pollock and others, 2005; } \\
\text { Corenblit and others., 2008) including aerial } \\
\text { photographs (Micheli and Kirchner, 2002a), } \\
\text { Quickbird (Johansen and others, 2007), } \\
\text { LiDAR (Johansen and others, 2010a), }\end{array}$ \\
\hline & & $\begin{array}{l}\text { Canopy cover in the field (Columbia Habitat } \\
\text { Monitoring Program, 2012) or overhanging } \\
\text { vegetation using GIS and LiDAR (Johansen } \\
\text { and others, 2010a,b) }\end{array}$ \\
\hline & $\begin{array}{l}\text { Area of evapotranspiration or near } \\
\text { infrared reflectance }\end{array}$ & $\begin{array}{l}\text { CIR photographs (Loheide and others, 2009), } \\
\text { and FLIR (Loheide and Gorelick, 2005) }\end{array}$ \\
\hline $\begin{array}{l}\text { Reduce and/or remove } \\
\text { invasive species }\end{array}$ & $\begin{array}{l}\text { Size, density, cover, and rate of } \\
\text { recruitment by invasive, noxious, or } \\
\text { other site inappropriate species }\end{array}$ & Same as above \\
\hline $\begin{array}{l}\text { Increase riparian function } \\
\text { of site-appropriate } \\
\text { native vegetation (for } \\
\text { restoration projects with } \\
\text { plantings) }\end{array}$ & $\begin{array}{l}\text { Percent survival (number of trees/shrubs } \\
\text { alive by number of trees/shrubs planted } \\
* 100 \text { ) - can report more specifically by } \\
\text { species, landform, or distance from } \\
\text { stream; percent damage by animal }\end{array}$ & $\begin{array}{l}\text { Field observations along transects or plots } \\
\text { (Dent, 2004) }\end{array}$ \\
\hline
\end{tabular}




\section{Example of the Need for Complementary Monitoring Approaches}

The restoration and effectiveness-monitoring approach at the Meacham Creek project are described briefly to illustrate the need for complementary monitoring methods at the reach and site scales. Effectiveness monitoring at Meacham Creek draws on many sources, including CHaMP, PHAMS references, and other sources from the scientific literature. Please contact the Fisheries Habitat Program Manager for the CTUIR Fisheries Habitat Program for details on this restoration project and related effectiveness monitoring.

\section{Limiting Factors and Restoration Actions at the Meacham Project}

In the Umatilla River Basin, Meacham Creek is the primary producer of summer steelhead-rainbow trout. Meacham Creek also supports spring Chinook salmon and bull trout. Habitat conditions for these fish in lower Meacham Creek, however, are limited by several factors related to hydrology, geomorphology, connectivity, and riparian vegetation (table 7). The main source of habitat degradation is construction and operation of the Union Pacific Railroad. In the early 1900s, the Union Pacific Railroad built levees and spur dikes, relocating and constraining the river channel against the valley wall opposite of the railroad. Since then, lower Meacham Creek has had decreased floodplain connectivity, riparian shade, recruitment of large wood, and variability in water depth, velocities, and graded sediment deposits. Prior to restoration, the channel lacked the structures needed to create and maintain complex instream habitat and temperature conditions needed to support spring Chinook, bull trout, and summer steelhead. Simplification of the Meacham Creek channel also reduced variability of subsurface flow path lengths that carry water through the floodplain (fig. 11).

Table 7. Limiting factors and restoration actions for the Meacham Creek restoration project, Umatilla River Basin, Oregon.

\begin{tabular}{lcccc}
\hline \multirow{2}{*}{ Limiting factor } & \multicolumn{3}{c}{ Restoration action } \\
\cline { 2 - 5 } & $\begin{array}{c}\text { Large wood } \\
\text { additions }\end{array}$ & $\begin{array}{c}\text { Levee removal and/or } \\
\text { set back }\end{array}$ & $\begin{array}{c}\text { Riparian } \\
\text { plantings }\end{array}$ & $\begin{array}{c}\text { Channel } \\
\text { realignment }\end{array}$ \\
\hline High stream temperatures & $\mathrm{X}$ & $\mathrm{X}$ & $\mathrm{X}$ & $\mathrm{X}$ \\
Lack of summer flow & $\mathrm{X}$ & $\mathrm{X}$ & $\mathrm{X}$ \\
Simplified channel & $\mathrm{X}$ & $\mathrm{X}$ & $\mathrm{X}$ \\
Limited quantity of pools & $\mathrm{X}$ & $\mathrm{X}$ & $\mathrm{X}$ \\
Lack of fish habitat complexity & $\mathrm{X}$ & $\mathrm{X}$ & $\mathrm{X}$ \\
Limited lateral connectivity & $\mathrm{X}$ & $\mathrm{X}$ & $\mathrm{X}$ \\
Altered sediment routing and sorting & $\mathrm{X}$ & & $\mathrm{X}$ \\
Limited quantities and recruitment of & $\mathrm{X}$ & $\mathrm{X}$ & $\mathrm{X}$ \\
$\quad$ large wood & & & $\mathrm{X}$ & \\
Loss and alteration of riparian & & & \\
$\quad$ vegetation, including introduction of & & & & \\
many invasive, non-native plant & & & & \\
species & & & & \\
\hline
\end{tabular}



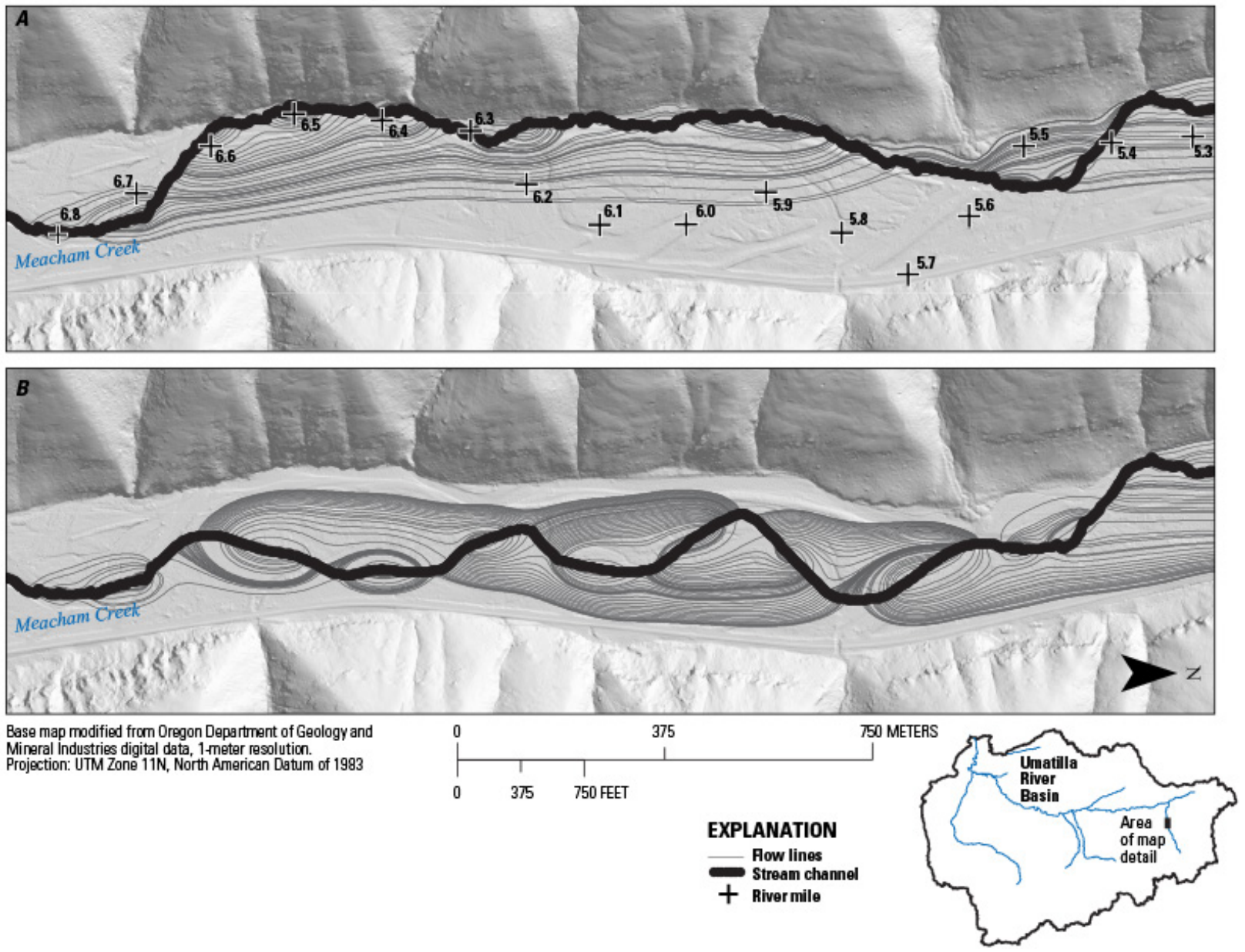

Figure 11. Isometric flow paths through the alluvial floodplain of Meacham Creek, Oregon. Isolines were generated using the MODTRACE module of MODFLOW. (A) Stream condition prior to restoration efforts. (B) New channel location and the resulting flow paths. This work is a part of Byron Amerson's dissertation research at Montana State University.

The CTUIR, in partnership with BPA and the U.S. Department of Agriculture Forest Service (USFS), has undertaken restoration actions to address the limiting factors in lower Meacham Creek (table 7; table 8). Actions include the removal or modifications of levees and spur dikes, additions of large wood jams, and reinstatement of geomorphic and hydrologic processes. The objectives of these actions are intended to address the limiting factors listed in table 7. That is, the restoration objectives are to increase lateral connectivity, improve the abundance and diversity of riparian vegetation, increase wood and pool abundance, and reduce stream temperatures. 
Table 8. Locations, restoration years, and project descriptions for the Meacham Creek restoration project, Umatilla River Basin, Oregon.

[Abbreviations: UPRR, Union Pacific Railroad]

\begin{tabular}{ccc}
\hline $\begin{array}{c}\text { River } \\
\text { Mile }\end{array}$ & $\begin{array}{c}\text { Year of } \\
\text { restoration }\end{array}$ & \multicolumn{1}{c}{ Description of restoration actions } \\
\hline 5 to 6 & 2009 & $\begin{array}{l}\text { Removal of four levees, placement of LWD, and riparian vegetation plantings } \\
\text { Removal of a 2,800-foot long levee, modification of two spur dikes in the floodplain, } \\
\text { construction of a rock embankment to protect the UPRR railway and access road, } \\
\text { realignment of Meacham Creek into its historical channel and meanders, addition of large } \\
\text { wood and other habitat structures to the realigned channel, and riparian plantings } \\
\text { throughout the floodplain. }\end{array}$ \\
7 to 8.5 & 2011 & $\begin{array}{l}\text { Several levees were removed or pulled back to allow the stream to access the floodplain. } \\
\text { Multiple large wood installations were constructed in the channel and floodplain and are } \\
\text { expected to further enhance the range of substrate sizes and accompanying natural } \\
\text { recruitment of vegetation across the floodplain. }\end{array}$ \\
\hline
\end{tabular}

\section{Monitoring Discussion}

The CTUIR has been monitoring habitat conditions in the Meacham Creek Basin to evaluate changes over time and the effectiveness of restoration projects, in particular those that remove or modify levees and spur dikes, add large wood, and plant vegetation (Andrus and Middel, 2003). Ongoing data collection focuses on river mile (RM) 2.5-3 (lower site; future treatment reach), RM 5.5-6 (middle site; treated reach), and RM 8.5-9 (upper site; untreated reach).

Post-restoration monitoring along Meacham Creek draws upon methods from CHaMP, PHAMS, and other monitoring approaches (tables 9-12). Each metric selected for monitoring is intended to track improvements in habitat that result from restoration actions. The Meacham monitoring approach underscores the importance of having multiple, complimentary options for restoration monitoring. For instance, CHaMP protocols are used to derive several metrics, such as primary channel length, bank stability, shade, and sediment size in the channel. Meanwhile, PHAMS references were used to derive other metrics, such as those related to braiding, river complexity, channel migration, and thermal diversity. Other metrics were identified outside of ChaMP and PHAMS as needed to capture key physical responses to the restoration actions at the Meacham site.

As of 2015, BPA, project sponsors, and others implement ChaMP protocols to measure the success of restoration projects in the Columbia River Basin. Primary channel length, sinuosity, bank stability, instream sediment sizes, and shade are some of the limiting factors that are captured by the CHaMP protocols. Stream temperature diversity, lack of summer flows, channel simplification, and habitat complexity are some limiting factors addressed less thoroughly by the CHaMP protocols. Below, we highlight some examples of when complimentary monitoring approaches like those in PHAMS may be helpful for supplementing CHaMP and other existing monitoring approaches. 
- The ChaMP methods yield a suite of metrics from detailed, longitudinal profiles of bed and water surface elevations and habitat data, such as the location and depth of riffle crest and pools. Supplementary datasets are generated from the longitudinal profiles. Longitudinal channel profiles alone do not capture the number and diversity of features such as islands, bars, and secondary channels within the active channel. Instead, the CTUIR uses the River Complexity Index (RCI; Brown, 2002) to represent the diversity of channel types before and after restoration.

- The integrated measures in CHaMP provide an extensive amount of habitat data, but they do not address several types of alluvial features, including spring brooks or floodplain ponds that are connected to the mainstem channel during high flows. Recent studies have found that floodplain spring brooks are one of the most productive salmon habitats and provide spawning and rearing habitats for several salmon species (Jasper and Molyneaux, 2007). Spring brooks are defined as alluvial flood channels that are predominantly fed by upwelling hyporheic-groundwater (Stanford and others, 2005) and, when compared with the main channel, provide a distinctly different suite of environmental conditions for salmon spawning and rearing. Floodplain ponds have been created through channel avulsions that have abandoned deep pools. Examples on the Umatilla River floodplain include pools that have been isolated from annual flooding over time by vegetation growth and establishment. However, these ponds are surface expressions of the alluvial aquifer and among the most productive environments on the floodplain surface (Branton and Richardson, 2014). Alternative methods for characterizing changes in these features include analyzing pre and post project LiDAR and high resolution aerial photography for planform metrics identified in the Geomorphology chapter of this report.

- The CHaMP surveys were not designed to collect data on identified limiting factors such as non-normal stream temperatures and lack of flows. A single discharge measurement on a particular day is unlikely to capture low flow conditions for reaches gaining and losing discharge to the alluvial aquifer (Woessner, 2000) or to identify dewatered areas within a reach. Similarly, one temperature logger cannot capture spatially diverse thermal conditions, particularly in reaches with multi-thread channels where hyporheic inputs affect water temperatures. Capturing this habitat condition pre and post restoration is important because surface water-groundwater interactions have been linked to redd site selection by spawning salmons and the survival of embryos (Baxter and Hauer, 2000; Geist and others, 2002). Improving surface water-groundwater interactions to support salmon populations is a key goal of the Meacham Creek site restoration effort. Other methods are needed to capture changes in these limiting factors because the Meacham Creek restoration site is in an alluvial valley where thermal conditions are influenced by hyporheic exchange. Such methods are actively being developed by Byron Amerson and colleagues at Montana State University for the Meacham Creek site.

In conclusion, the monitoring efforts at the Meacham Creek floodplain site illustrate the importance of having a flexible monitoring framework that allows project leaders to select methods as needed to document changes and restoration effectiveness. A "one size fits all" approach may not capture the suite of physical and biological metrics, particularly those metrics measured at the reach scale. As a result, PHAMS is intended to compliment other effectiveness monitoring efforts in the region by identifying reach-scale metrics suitable for larger alluvial river valleys with reach-scale restoration efforts. 
Table 9. Instream metrics and methods for the Meacham Creek effectiveness monitoring.

[Abbreviations: CHaMP, Columbia Habitat Monitoring Program; PHAMS, Physical HAbitat Monitoring Strategy]

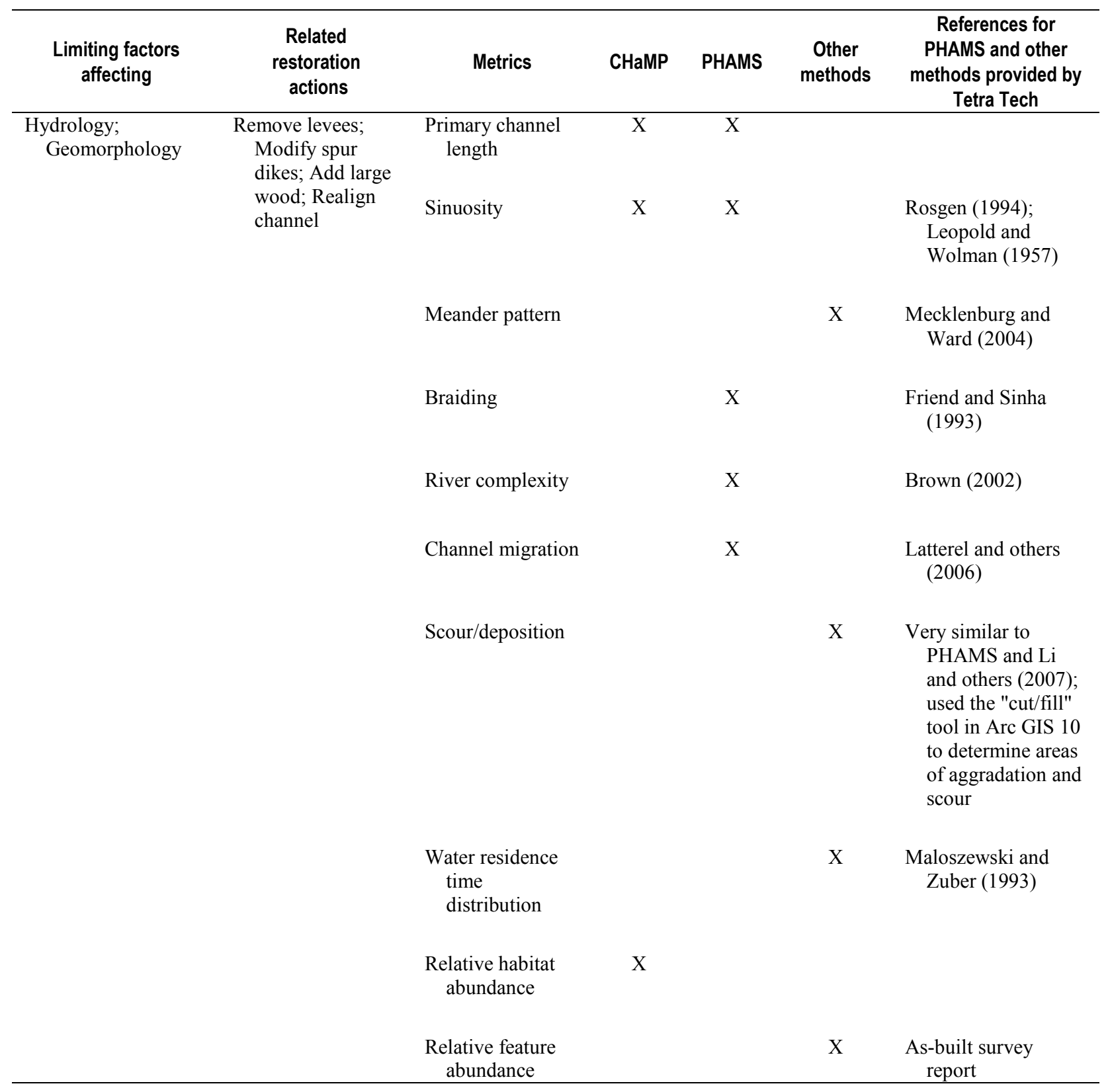


Table 10. Riparian and floodplain metrics and methods for the Meacham Creek effectiveness monitoring.

[Abbreviations: CHaMP, Columbia Habitat Monitoring Program; PHAMS, Physical HAbitat Monitoring Strategy]

\begin{tabular}{|c|c|c|c|c|c|c|}
\hline $\begin{array}{l}\text { Limiting factors } \\
\text { affecting }\end{array}$ & $\begin{array}{l}\text { Related } \\
\text { restoration } \\
\text { actions }\end{array}$ & Metrics & CHaMP & PHAMS & $\begin{array}{c}\text { Other } \\
\text { methods }\end{array}$ & $\begin{array}{l}\text { References for } \\
\text { PHAMS and other } \\
\text { methods provided by } \\
\text { Tetra Tech }\end{array}$ \\
\hline \multirow[t]{8}{*}{$\begin{array}{l}\text { Riparian and } \\
\text { floodplain } \\
\text { conditions }\end{array}$} & $\begin{array}{l}\text { Plant native } \\
\text { vegetation; } \\
\text { Increase } \\
\text { channel } \\
\text { complexity; }\end{array}$ & $\begin{array}{l}\text { Relative abundance } \\
\text { and distribution of } \\
\text { native riparian } \\
\text { species }\end{array}$ & $\mathrm{X}$ & & & \\
\hline & Remove levees & Bank stability & $X$ & & & \\
\hline & & $\begin{array}{l}\text { Large wood } \\
\text { recruitment }\end{array}$ & & & & $\begin{array}{l}\text { Large wood for designed } \\
\text { structures is evaluated } \\
\text { using as-built survey } \\
\text { report. CHaMP records } \\
\text { large wood tallies. No } \\
\text { large wood recruitment } \\
\text { analysis completed. }\end{array}$ \\
\hline & & Shade & $\mathrm{X}$ & & & \\
\hline & & $\begin{array}{l}\text { Floodplain } \\
\text { inundation }\end{array}$ & & & $\mathrm{X}$ & $\begin{array}{l}\text { Ackerman and others } \\
\text { (2010); ArcGIS } 10 \text { Geo- } \\
\text { RAS tool }\end{array}$ \\
\hline & & Channel migration & & $\mathrm{X}$ & & Latterell and others (2006) \\
\hline & & $\begin{array}{l}\text { Change in the } \\
\text { probability } \\
\text { distribution of } \\
\text { flowpaths }\end{array}$ & & $\mathrm{X}$ & & Poole and others (2008) \\
\hline & & $\begin{array}{l}\text { Relative abundance } \\
\text { of floodplain } \\
\text { habitats }\end{array}$ & $X$ & & $\mathrm{X}$ & $\begin{array}{l}\text { Utilized As-Built survey } \\
\text { data. Habitats and side- } \\
\text { channels were } \\
\text { documented according } \\
\text { the CHaMP definitions } \\
\text { in CHaMP surveys. }\end{array}$ \\
\hline
\end{tabular}


Table 11. Sediment metrics and methods for the Meacham Creek effectiveness monitoring.

[Abbreviations: CHaMP, Columbia Habitat Monitoring Program; CTUIR, Confederated Tribes of the Umatilla Indian Reservation; PHAMS, Physical HAbitat Monitoring Strategy]

\begin{tabular}{|c|c|c|c|c|c|c|}
\hline $\begin{array}{l}\text { Limiting factors } \\
\text { affecting }\end{array}$ & $\begin{array}{l}\text { Related } \\
\text { restoration } \\
\text { actions }\end{array}$ & Metrics & CHaMP & PHAMS & $\begin{array}{l}\text { Other } \\
\text { methods }\end{array}$ & $\begin{array}{l}\text { References for } \\
\text { PHAMS and other } \\
\text { methods provided by } \\
\text { Tetra Tech }\end{array}$ \\
\hline \multirow[t]{5}{*}{$\begin{array}{l}\text { Hydrology; } \\
\text { Geomorphology }\end{array}$} & $\begin{array}{l}\text { Remove levees; } \\
\text { Modify spur } \\
\text { dikes; Add } \\
\text { large wood; } \\
\text { Realign } \\
\text { channel }\end{array}$ & $\begin{array}{l}\text { Sediment size } \\
\text { distribution, in } \\
\text { channel } \\
\text { Sediment size } \\
\text { distribution, in } \\
\text { bars }\end{array}$ & $X$ & $X$ & & $\begin{array}{l}\text { Surface, subsurface, and } \\
\text { bulk samples were } \\
\text { conducted to determine } \\
\text { sediment size } \\
\text { distribution in bars; } \\
\text { combination of PHAMS } \\
\text { methods }\end{array}$ \\
\hline & & $\begin{array}{l}\text { Sediment size } \\
\text { distribution, in } \\
\text { floodplain }\end{array}$ & & & $\mathrm{X}$ & $\begin{array}{l}\text { Test pits were conducted to } \\
\text { determine floodplain } \\
\text { substrate distribution and } \\
\text { appropriate alignment for } \\
\text { constructed channels in } \\
\text { 2010. Post-project data } \\
\text { for this metric has not yet } \\
\text { been collected as the } \\
\text { channel continues to } \\
\text { stabilize and redistribute } \\
\text { sediment. }\end{array}$ \\
\hline & & Sediment sources & & & $\mathrm{X}$ & $\begin{array}{l}\text { Calculated using Shield's } \\
\text { threshold of motion } \\
\text { equation; Measured } \\
\text { channel aggradation } \\
\text { (Wheaton and others, } \\
\text { 2010a,b) }\end{array}$ \\
\hline & & Sediment budget & & & $\mathrm{X}$ & $\begin{array}{l}\text { Calculated using Shield's } \\
\text { threshold of motion } \\
\text { equation; Measured } \\
\text { channel aggradation } \\
\text { (Wheaton and others, } \\
\text { 2010a,b) }\end{array}$ \\
\hline & & $\begin{array}{l}\text { Relative } \\
\text { abundance of } \\
\text { spawning and } \\
\text { rearing habitat }\end{array}$ & & & $\mathrm{x}$ & CTUIR $(2009,2012)$ \\
\hline
\end{tabular}


Table 12. Stream temperature metrics and methods for the Meacham Creek effectiveness monitoring.

[Abbreviations: CHaMP, Columbia Habitat Monitoring Program; PHAMS, Physical HAbitat Monitoring Strategy]

\begin{tabular}{|c|c|c|c|c|c|c|}
\hline $\begin{array}{l}\text { Limiting factors } \\
\text { affecting }\end{array}$ & $\begin{array}{l}\text { Related } \\
\text { restoration } \\
\text { actions }\end{array}$ & Metrics & CHaMP & PHAMS & $\begin{array}{l}\text { Other } \\
\text { methods }\end{array}$ & $\begin{array}{c}\text { References for } \\
\text { PHAM S and other } \\
\text { methods provided by } \\
\text { Tetra Tech }\end{array}$ \\
\hline \multirow[t]{4}{*}{$\begin{array}{l}\text { Stream } \\
\text { temperature }\end{array}$} & $\begin{array}{l}\text { Remove levees; } \\
\text { Modify spur } \\
\text { dikes; Add large } \\
\text { wood; Realign }\end{array}$ & $\begin{array}{l}\text { Water - mean } \\
\text { residence time } \\
\text { distribution }\end{array}$ & & & $\mathrm{X}$ & $\begin{array}{l}\text { Maloszewski and Zuber } \\
\text { (1993) }\end{array}$ \\
\hline & channel & $\begin{array}{l}\text { Surface and } \\
\text { subsurface } \\
\text { temperature }\end{array}$ & & & $\mathrm{X}$ & $\begin{array}{l}\text { Amerson and others } \\
\quad \text { (written commun., 2014) }\end{array}$ \\
\hline & & Thermal diversity & & $\mathrm{X}$ & & $\begin{array}{l}\text { Torgersen and others } \\
\text { (1999) }\end{array}$ \\
\hline & & $\begin{array}{l}\text { Changes in } \\
\text { buffering and } \\
\text { lagging }\end{array}$ & & $\mathrm{X}$ & & Arrigoni and others (2008) \\
\hline
\end{tabular}

\section{Conclusions}

Existing habitat and restoration monitoring efforts such as CHaMP and PIBO have not included reach-scale monitoring parameters that are important indicators of the success or failure of large restoration projects such as floodplain reconnection. This report attempts to address that gap by providing summary guidance for selecting reach-scale monitoring parameters for restoration projects enacted by the CTUIR Fisheries Habitat Program. Project types were organized according to the four River Vision touchstones: hydrology, geomorphology, connectivity, and riparian vegetation. For each project type, we provided simple tables of typical project objectives and potential monitoring parameters that are suitable for evaluating whether a project meets its stated objectives. Some of these parameters have already been adopted by both the CTUIR and the BPA Action Effectiveness Monitoring program for monitoring effectiveness of restoration actions, and as well as by Puget Sound Habitat Status and Trend Monitoring program at the NW Fisheries Science Center.

Based on the guidance in this report, CTUIR staff and other groups can monitor largescale restoration actions with a broader suite of metrics that better indicate whether projects are effectively creating large habitat features that are expected. For example, floodplain reconnection projects are often expected to create more main channel and off-channel habitat, and metrics such as sinuosity or the braiding index are direct measures of those features. We have also provided limited guidance on designing a monitoring plan for single restoration actions, which is perhaps most useful to the CTUIR and other groups monitoring individual projects. Future work could provide guidance for developing monitoring plans for multiple projects, or may suggest coordination with other groups doing such monitoring (e.g., the BPA Action Effectiveness Monitoring program). 


\section{Acknowledgments}

PHAMS was supported by funds from the Bonneville Power Administration and USGS Cooperative Water Program. The authors extend special thanks to the Michael Lambert, Les Naylor, and Johnathan Thompson from the CTUIR Fisheries Habitat Program, who provided input on earlier drafts of PHAMS and Chris James from Tetra-Tech, Inc. who provided input on the Meacham Creek example. We would also like to thank Mackenzie Keith with the USGS Oregon Water Science Center for her assistance in completing this report.

\section{References Cited}

Ackerman, C.T., Jensen, M.R., and Brunner, G.W., 2010, Geospatial capabilities of HEC-RAS for model development and mapping, in Joint Federal Agency Conference, 2nd, Las Vegas, Nevada, June 27-July 1, 2010: Las Vegas, Nevada, Joint Federal Interagency, http://acwi.gov/sos/pubs/2ndJFIC/Contents/1F_Ackerman_3_1_10\%282\%29.pdf.

Amoros, Claude, and Bornette, Gudrun, 2002, Connectivity and biocomplexity in waterbodies of riverine floodplains: Freshwater Biology, v. 47, no. 4, p. 761-776, doi:10.1046/j.13652427.2002.00905.x.

Andrus, Chip, and Middel, Jerry, 2003, Meacham Creek watershed analysis and action plan: Water Work Consulting and Duck Creek Associates, 125 p., http://data.ctuir.org/fisheries/downloads/Meacham_Creek_Watershed_Analysis_and_Action_ Plan_Final_Report_2003.pdf.

Archer, E.K., Van Wagenen, A.R., Coles-Ritchie, Mark, Ebertowski, Peter, Becker, A.D., Uhler, K.B., Eskandari, P.G., Babich, Lev, and Leary, R.J., 2012, Effectiveness monitoring for streams and riparian areas-Sampling protocol for vegetation parameters: Logan, Utah, PACFISH/INFISH Biological Opinion Effectiveness Monitoring Program (PIBO-EMP) Staff Multi Federal Agency Monitoring, 60 p.,

http://www.fs.fed.us/biology/resources/pubs/feu/pibo/pibo_veg_sampling_protocol_2012.pdf.

Arrigoni, A.S., Poole, G.C., Mertes, L.A. K., O'Daniel, S.J., Woessner, W.W., and Thomas, S.A., 2008, Buffered, lagged, or cooled? Disentangling hyporheic influences on temperature cycles in stream channels: Water Resources Research, v. 44, no. 9, 10.1029/2007wr006480, p. W09418.

Arroyo, L.A., Johansen, Kasper, Armston, John, and Phinn, Stuart, 2010, Integration of LiDAR and QuickBird imagery for mapping riparian biophysical parameters and land cover types in Australian tropical savannas: Forest Ecology and Management, v. 259, no. 3, p. 598-606, http://dx.doi.org/10.1016/j.foreco.2009.11.018.

Arscott, David, Tockner, Klement, and Ward, J.V., 2001, Thermal heterogeneity along a braided floodplain river (Tagliamento River, northeastern Italy): Canadian Journal of Fisheries and Aquatic Sciences, v. 58, no. 12, p. 2,359-2,373, doi: 10.1139/cjfas-58-12-2359.

Barbour, M.T., Gerritsen, J., Snyder, B.D., and Stribling, J.B., 1999, Rapid bioassessment protocols for use in streams and wadeable rivers: Periphyton, benthic macroinvertebrates and fish, Second Edition, EPA 841-B-99-002, U.S. Environmental Protection Agency, Office of Water, Washington, D.C., http://water.epa.gov/scitech/monitoring/rsl/bioassessment/.

Baxter, C.V., and Hauer, F.R., 2000, Geomorphology, hyporheic exchange, and selection of spawning habitat by bull trout (Salvelinus confluentus): Canadian Journal of Fisheries and Aquatic Sciences, v. 57, no. 7, p. 1,470-1,481, doi:10.1139/f00-056. 
Beechie, T.J., Beamer, Eric, and Wasserman, Larry, 1994, Estimating coho salmon rearing habitat and smolt production losses in a large river basin, and implications for habitat restoration: North American Journal of Fisheries Management, v. 14, no. 4, p. 797-811, doi:10.1577/1548-8675(1994)014<0797:ecsrha $>2.3 . c 0 ; 2$, .

Beechie, T.J. and Sibley, T.H., 1997, Relationships between channel characteristics, woody debris, and fish habitat in northwestern Washington streams: Transactions of the American Fisheries Society, v. 126, no. 2, p. 217-229, 10.1577/1548-

8659(1997)126<0217:rbccwd >2.3.co; 2 .

Beechie, T.J., Veldhuisen, C.N., Schuett-Hames, D.E., DeVries, Paul, Conrad, R.H., and Beamer, E.M., 2005, Monitoring treatments to reduce sediment and hydrologic effects from roads, in Roni, Philip, ed., Methods for monitoring stream and watershed restoration: Bethesda, Md., American Fisheries Society, p. 35-65.

Beechie, T.J., Liermann, Martin, Pollock, M.M., Baker, Sarah, and Davies, Jeremy, 2006, Channel pattern and river-floodplain dynamics in forested mountain river systems: Geomorphology, v. 78, no. 1-2, p. 124-141, 10.1016/j.geomorph.2006.01.030.

Beechie, T.J., Pollock, M. M., and Baker, Sarah, 2008, Channel incision, evolution and potential recovery in the Walla Walla and Tucannon River basins, northwestern USA: Earth Surface Processes and Landforms, v. 33, no. 5, p. 784-800.

Beechie, T.J., Sear, D.A., Olden, J.D., Pess, G.R., Buffington, J.M., Moir, Hamish, Roni, Philip, and Pollock, M.M., 2010, Process-based principles for restoring river ecosystems: BioScience, v. 60 , no. 3, p. 209-222.

Beechie, T.J., Pess, George, Morley, Sarah, Butler, Lucy, Downs, Peter, Maltby, Alistar, Skidmore, Peter, Clayton, Steve, Muhlfeld, Clint, and Hanson, Karrie, 2013, Watershed assessments and identification of restoration needs, in Roni, Phil, and Beechie, Tim, eds., Stream and watershed restoration - A guide to restoring riverine processes and habitats: Chichester, U.K., Wiley-Blackwell, p. 20-113.

Benda, Lee and Dunne, Thomas, 1997, Stochastic forcing of sediment supply to channel networks from landsliding and debris flow: Water Resources Research, v. 33, no. 12, p. 2,8492,863, 10.1029/97wr02388.

Benda, Lee, Andras, Kevin, Miller, Daniel, and Bigelow, Paul, 2004, Confluence effects in rivers - Interactions of basin scale, network geometry, and disturbance regimes: Water Resources Research, v. 40, no. 5, 10.1029/2003wr002583, p. W05402.

Bergstrom, F.W., 1982, Episodic behavior in badlands-Its effects on channel morphology and sediment yields, in Swanson, F.J., Janda, E.J., Dunne, Thomas, and Swanson, D.N., eds., Sediment budgets and routing in forested drainage basins: Portland, Oregon, U.S. Forest Service General Technical Report PNW-141, p. 59-66.

Biggs, T.W., Dunne, Thomas, Domingues, Tomas Ferreira, and Martinelli, L.A., 2002, Relative influence of natural watershed properties and human disturbance on stream solute concentrations in the southwestern Brazilian Amazon basin: Water Resources Research, v. 38, no. 8, p. 25-1-25-16, http://onlinelibrary.wiley.com/doi/10.1029/2001WR000271/pdf.

Bisson, P.A., Sullivan, Kathleen, and Nielsen, J.L., 1988, Channel hydraulics, habitat use, and body form of juvenile coho salmon, steelhead, and cutthroat trout in streams: Transactions of the American Fisheries Society, v. 117, no. 3, p. 262-273, doi:10.1577/15488659(1988) $117<0262$ :chhuab $>2.3 . c 0 ; 2$.

Bjornn, T.C. and Reiser, D.W., 1991, Habitat requirements of salmonids in streams, in Meehan, W.R., ed., Influences of forest and rangeland management of salmonid fishes and their habitat: Bethesda, Md., American Fisheries Society, v. 19, p. 83-138. 
Boulton, A.J., 1993, Stream ecology and surface-hyporheic hydrologic exchange-Implications, techniques and limitations: Marine and Freshwater Research, v. 44, no. 4, p. 553-564, http://dx.doi.org/10.1071/MF9930553.

Braatne, J.H., Rood, S.B., and Heilman, P.E., 1996, Life history, ecology, and conservation of riparian cottonwoods in North America, in Stettler, R.F., Bradshaw, H.D., and Hinkley, T.M., eds., Biology of populus and its implications for management and conservation: Ottawa, Ontario, Canada, National Research Council, p. 57-85.

Branton, M.A., and Richardson, J.S., 2014, A test of the umbrella species approach in restored floodplain ponds: Journal of Applied Ecology, v. 51, no. 3, p. 776-785, doi:10.1111/13652664.12248.

Brookshire, J.E., Kauffman, B.J., Lytjen, Danna, and Otting, Nick, 2002, Cumulative effects of wild ungulate and livestock herbivory on riparian willows: Oecologia, v. 132, no. 4, p. 559566, doi:10.1007/s00442-002-1007-4.

Brown, A.G., 2002, Learning from the past-Palaeohydrology and palaeoecology: Freshwater Biology, v. 47, no. 4, p. 817-829, doi:10.1046/j.1365-2427.2002.00907.x.

Buffington, J.M., and Montgomery, D.R., 1999, A procedure for classifying textural facies in gravel-bed rivers: Water Resources Research, v. 35, no. 6, p. 1,903-1,914, doi:10.1029/1999wr900041.

Bull, L.J., 1997, Magnitude and variation in the contribution of bank erosion to the suspended sediment load of the River Severn, UK: Earth Surface Processes and Landforms, v. 22, no. 12, p. 1,109-1,123, 10.1002/(sici)1096-9837(199712)22:12<1109::aid-esp810>3.0.co;2-o.

Bunte, Kristin, and Abt, S.R., 2001, Sampling surface and subsurface particle-size distributions in wadeable gravel- and cobble-bed streams for analyses in sediment transport, hydraulics, and streambed monitoring: Fort Collins, Colo., U.S. Department of Agriculture Forest Service, Rocky Mountain Research Station, General Technical Report RMRS-GTR-74, 428 p.

Bureau of Reclamation, 2012, SRH-2D Version 2.2: Bureau of Reclamation.

Church, Michael, 1983, Pattern of instability in a wandering gravel bed channel: Special Publications of the International Association of Sedimentologists, v. 6, p. 169-180.

Church, Michael, 2002, Geomorphic thresholds in riverine landscapes: Freshwater Biology, v. 47, no. 4, p. 541-557, doi:10.1046/j.1365-2427.2002.00919.x.

Clarke, Sharon, 2004, Remote Sensing, in Hoobyar, P., ed., Oregon plan for salmon and watersheds-Oregon Riparian Assessment Framework, chap. 6, p. 62-90.

Collins, B.D., Montgomery, D.R., Fetherston, K.L., and Abbe, T.B., 2012, The floodplain largewood cycle hypothesis-A mechanism for the physical and biotic structuring of temperate forested alluvial valleys in the North Pacific coastal ecoregion: Geomorphology, v. 139-140, p. $460-470$.

Columbia Habitat Monitoring Program, 2012, Scientific protocol for salmonid habitat surveys within the Columbia Habitat Monitoring Program: Wauconda, Washington, Terraqua, Inc., 172 p., http://www.champmonitoring.org/Program/RetreiveProgramDocumentFile/1/Protocol\%20Do cuments/1113376526.

Confederated Tribes of the Umatilla Indian Reservation, 2009, Biomonitoring of fish habitat enhancement: Mission, Oreg., BPA Project \# 2009-014-00, 18 p.

Confederated Tribes of the Umatilla Indian Reservation, 2012, Meacham Creek floodplain restoration and in-stream enhancement project completion report: Tetra Tech, Inc., Bothell, Washington. 
Cooper, D.J., Lundquist, J.D., King, John, Flint, Alan, Flint, Lorraine, Wolf, Evan, Lott, F.C., and Roche, James, 2006, Effects of the Tioga Road on hydrologic processes and lodgepole pine invasion into Tuolumne Meadows, Yosemite National Park: Report Prepared for Yosemite National Park, 146 p., http://faculty.washington.edu/jdlund/publications/Tuolumne_Report_FINAL.pdf.

Corenblit, Dov, Tabacchi, Eric, Steiger, Johannes, and Gurnell, A.M., 2007, Reciprocal interactions and adjustments between fluvial landforms and vegetation dynamics in river corridors-A review of complementary approaches: Earth-Science Reviews, v. 84, no. 1-2, p. 56-86.

Corenblit, Dov, Gurnell, A.M., Steiger, Johannes, and Tabacchi, Eric, 2008, Reciprocal adjustments between landforms and living organisms: Extended geomorphic evolutionary insights: Catena, v. 73, no. 3, 10.1016/j.catena.2007.11.002, p. 261-273.

Dent, C.L., Grimm, N.B., and Fisher, S.G., 2001, Multiscale effects of surface-subsurface exchange on stream water nutrient concentrations: Journal of the North American Benthological Society, v. 20, no. 2, p. 162-181, doi:10.2307/1468313.

Dent, Liz, 2004, Field methods, in Hoobyar, P., ed., Oregon plan for salmon and watershedsOregon Riparian Assessment Framework, p. 34-61.

Dietrich, W.E., Kirchner, J.W., Ikeda, Hiroshi, and Iseya, Fujiko, 1989, Sediment supply and the development of the coarse surface layer in gravel-bedded rivers: Nature, v. 340, no. 6,230, p. 215-217.

Dunne, Thomas, and Leopold, L.B, 1978, Water in environmental planning: San Francisco, California, W.H. Freeman and Co., 818 p.

Dwire, Kathleen, Kauffman, J., and Baham, John, 2006, Plant species distribution in relation to water-table depth and soil redox potential in montane riparian meadows: Wetlands, v. 26, no. 1, p. 131-146, doi:10.1672/0277-5212(2006)26[131:psdirt]2.0.co;2.

Everest, F.H., and Chapman, D.W., 1972, Habitat selection and spatial interaction by juvenile Chinook salmon and steelhead trout in two Idaho streams: Journal of the Fisheries Research Board of Canada, v. 29, no. 1, p. 91-100, doi:10.1139/f72-012.

Friend, P.F., and Sinha, Rajiv, 1993, Braiding and meandering parameters, in Best, J.L., and Bristow, C.S., eds., Braided Rivers: Geological Society Special Publication, v. 75, p. 105-111. Fullerton, A.H., Torgersen, C.E., Lawler, J.J., Faux, R.N., Steel, E.A., Beechie, T.J., Ebersole, J.L., and Leibowitz, S.G., in review, Rethinking the longitudinal stream temperature paradigm: region-wide comparison of thermal infrared imagery reveals unexpected complexity of river temperatures: Hydrological Processes.

Geist, D.R., Hanrahan, T.P., Arntzen, E.V., McMichael, G.A., Murray, C.J., and Chien, Yi-Ju, 2002, Physicochemical characteristics of the hyporheic zone affect redd site selection by chum salmon and fall Chinook salmon in the Columbia River: North American Journal of Fisheries Management, v. 22, no. 4, doi:10.1577/1548-8675(2002)022<1077:pcothz>2.0.co;2, p. 10771085.

Goetz, S.J., 2006, Remote sensing of riparian buffers-Past progress and future prospects: Journal of the American Water Resources Association, v. 42, no. 1, p. 133-143, doi:10.1111/j.1752-1688.2006.tb03829.x.

Goovaerts, Pierre, 1997, Geostatistics for natural resources: Oxford, New York Oxford University Press, Applied Geostatistical Series, 483 p.

Grayson, R.B., Argent, R.M., Nathan, R.J., McMahon, T.A., and Mein, R.G., 2004, Hydrological recipes-Estimation techniques in Australian hydrology: Clayton, Australia, Cooperative Research Centre for Catchment Hydrology, 125 p. 
Gregory, S.V., Swanson, F.J., McKee, W.A., and Cummins, K.W., 1991, An ecosystem perspective of riparian zones: BioScience, v. 41, no. 8, p. 540-551.

Grost, R. T., Hubert, W.A., and Wesche, T.A., 1991, Field comparison of three devices used to sample substrate in small streams: North American Journal of Fisheries Management v. 11, p. 347-351.

Gurnell, A.M., Piégay, Hervé, Swanson, F.J., and Gregory, S.V., 2002, Large wood and fluvial processes: Freshwater Biology, v. 47, no. 4, p. 601-619, doi:10.1046/j.13652427.2002.00916.x.

Gurnell, A.M., Boitsidis, A.J., Thompson, Ken, and Clifford, N.J., 2006, Seed bank, seed dispersal and vegetation cover: colonization along a newly-created river channel: Journal of Vegetation Science, v. 17, no. 5, p. 665-674.

Gurnell, A.M., O'Hare, J.M., O'Hare, M.T., Dunbar, M.J., and Scarlett, P.M., 2010, An exploration of associations between assemblages of aquatic plant morphotypes and channel geomorphological properties within British rivers: Geomorphology, v. 116, no. 1-2, p. 135144, http://dx.doi.org/10.1016/j.geomorph.2009.10.014.

Gurnell, A.M., Bertoldi, Walter, and Corenblit, Dov, 2012, Changing river channels - The roles of hydrological processes, plants and pioneer fluvial landforms in humid temperate, mixed load, gravel bed rivers: Earth-Science Reviews, v. 111, no. 1-2, p. 129-141.

Hall, J.E., Holzer, D.M., and Beechie, T.J., 2007, Predicting river floodplain and lateral channel migration for salmon habitat conservation 1: Journal of the American Water Resources Association, v. 43, no. 3, p. 786-797, doi:10.1111/j.1752-1688.2007.00063.x.

Hammersmark, C.T., Dobrowski, S.Z., Rains, M.C., and Mount, J.F., 2010, Simulated effects of stream restoration on the distribution of wet-meadow vegetation: Restoration Ecology, v. 18, no. 6, p. 882-893, doi:10.1111/j.1526-100X.2009.00519.x.

Heimann, D.C., and Roell, M.J., 2000, Sediment loads and accumulation in a small riparian wetland system in northern Missouri: Wetlands, v. 20, no. 2, p. 219-231.

Hester, E.T., Doyle, M.W., and Poole, G.C., 2009, The influence of in-stream structures on summer water temperatures via induced hyporheic exchange: Limnology and Oceanography, v. 54, no. 1, p. 355-367, doi:10.4319/1o.2009.54.1.0355.

Jasper, J.R. and Molyneaux, D.B., 2007, Kogruluk River salmon studies: Alaska Department of Fish and Game, Fisheries Data Series No. 07-12, 104 p.

Jastram, J.D., Zipper, C.E., Zelazny, L.W., and Hyer, K.E., 2010, Increasing precision of turbidity-based suspended sediment concentration and load estimates: Journal of Environmental Quality, v. 39, no. 4, p. 1,306-1,316, doi:10.2134/jeq2009.0280.

Johansen, Kasper, Tiede, Dirk, Blaschke, Thomas, Arroyo, L.A., and Phinn, Stuart, 2011, Automatic geographic object based mapping of streambed and riparian zone extent from LiDAR data in a temperate rural urban environment, Australia: Remote Sensing, v. 3, no. 6, p. 1,139-1,156, http://www.mdpi.com/2072-4292/3/6/1139\#cite.

Johansen, Kasper, Phinn, Stuart, and Witte, Christian, 2010a, Mapping of riparian zone attributes using discrete return LiDAR, QuickBird and SPOT-5 imagery-Assessing accuracy and costs: Remote Sensing of Environment, v. 114, no. 11, p. 2,679-2,691, http://dx.doi.org/10.1016/j.rse.2010.06.004.

Johansen, Kasper, Arroyo, L.A., Armston, John, Phinn, Stuart, and Witte, Christian, 2010b, Mapping riparian condition indicators in a sub-tropical savanna environment from discrete return LiDAR data using object-based image analysis: Ecological Indicators, v. 10, no. 4, p. 796-807, http://dx.doi.org/10.1016/j.ecolind.2010.01.001. 
Johansen, Kasper, Coops, N.C., Gergel, S.E., and Stange, Yulia, 2007, Application of high spatial resolution satellite imagery for riparian and forest ecosystem classification: Remote Sensing of Environment, v. 110, no. 1, p. 29-44, http://dx.doi.org/10.1016/j.rse.2007.02.014.

Johnson, D.H., Shrier, B.M., O’Neal, J.S., Knutzen, J.A., Augerot, Xanthippe, O’Neil, T.A., and Pearsons, T.N., 2007, Salmonid field protocols handbook-Techniques for assessing status and trends in salmon and trout populations: Bethesda, Md., American Fisheries Society in Association with State of the Salmon, $478 \mathrm{p}$.

Jones, K.L., Poole, G.C., Quaempts, E.J., O’Daniel, Scott, and, Beechie, T.J., 2008, The Umatilla River Vision: Tucker, Georgia, Ecometrics, Inc. and the Confederated Tribes of the Umatilla Indian Reservation, and NOAA, $31 \mathrm{p}$.

Junk, W.J., Bayley, P.B., and Sparks, R.E, 1989, The flood pulse concept in river-floodplain systems, in Proceedings of the international large rivers symposium: Canadian Special Publication of Fisheries and Aquatic Sciences, v. 106, p. 106-127.

Kauffman, J.B, and Krueger, W.C., 1984, Livestock impacts on riparian ecosystems and streamside management implications-A review: Journal of Range Management, v. 37, no. 5, p. $430-438$.

Kleiss, B.A., 1996, Sediment retention in a bottomland hardwood wetland in eastern Arkansas: Wetlands, v. 16, no. 3, p. 321-333.

Kloehn, K.K., Beechie, T.J., Morley, S.A., Coe, H.J., and Duda, J.J., 2008, Influence of dams on river-floodplain dynamics in the Elwha River, Washington: Special Issue on Dam Removal and Ecosystem Restoration in the Elwha River Watershed, Washington State, Northwest Science, v. 82, p. 224-235.

Kondolf, G.M., Boulton, A.J., O’Daniel, Scott, Poole, G.C., Rahel, F.J., Stanley, E.H, Wohl, Ellen, Bång, Asa, Carlstrom, Julia, and Cristoni, Chiara, 2006, Process-based ecological river restoration-Visualizing three-dimensional connectivity and dynamic vectors to recover lost linkages: Ecology and Society, v. 11, no. 2, p. 5.

Langston, Nancy, 1995, Forest dreams, forest nightmares - The paradox of old growth in the inland West: Seattle, Washington, University of Washington Press, 368 p.

Larned, S.T., Datry, Thibault, Arscott, D.B., and Tockner, Klement, 2010, Emerging concepts in temporary-river ecology-Freshwater Biology, v. 55, no. 4, p. 717-738, doi:10.1111/j.13652427.2009.02322.x.

Latterell, J.J., Bechtold, J.S., O'Keefe, T.C., Van Pelt, Robert, and Naiman, R.J., 2006, Dynamic patch mosaics and channel movement in an unconfined river valley of the Olympic Mountains: Freshwater Biology, v. 51, no. 3, p. 523-544, doi:10.1111/j.1365-2427.2006.01513.x.

Leopold, L.B. and Wolman, M.G., 1957, River channel patterns-Braided, meandering and straight, in Physiographic and hydraulic studies of rivers: U.S. Geological Survey Professional Paper 282-B, p. 39-85.

Leopold, L.B., Wolman, M.G., and Miller, J.P., 1964, Fluvial processes in geomorphology: San Francisco, California, Freeman, p. 79-80.

Li, Luqian, Lu, XiXi, and Chen, Zhongyuan, 2007, River channel change during the last 50 years in the middle Yangtze River, the Jianli reach: Geomorphology, v. 85, p. 185-196.

Lisle, T.E., 1987, Using "residual depths" to monitor pool depths independently of discharge: Pacific Southwest Forest and Range Experiment Station, U.S. Forest Service Berkeley, California, $4 \mathrm{p}$.

Lisle, T.E., and Madej, M.A., 1992, Spatial variation in armouring in a channel with high sediment supply, in Billi, P., R.D.H., Thorne, C.R., and Tacconi, P., ed., Dynamics of gravelbed rivers: New York, John Wiley and Sons, Ltd., p. 277-293. 
Lisle, T.E., 1982, Effects of aggradation and degradation on riffle-pool morphology in natural gravel channels, northwestern California: Water Resources Research, v. 18, no. 6, p. 1,6431,651, doi:10.1029/WR018i006p01643.

Loheide, Steven, Deitchman, Richard, Cooper, David, Wolf, Evan, Hammersmark, Christopher, and Lundquist, Jessica, 2009, A framework for understanding the hydroecology of impacted wet meadows in the Sierra Nevada and Cascade Ranges, California, USA: Hydrogeology Journal, v. 17, no. 1, p. 229-246, doi:10.1007/s10040-008-0380-4.

Loheide, S.P., and Gorelick, S.M., 2005, A local-scale, high-resolution evapotranspiration mapping algorithm (ETMA) with hydroecological applications at riparian meadow restoration sites: Remote Sensing of Environment, v. 98, no. 2-3, p. 182-200, doi:10.1016/j.rse.2005.07.003.

Loheide, S.P., and Gorelick, S.M., 2007, Riparian hydroecology-A coupled model of the observed interactions between groundwater flow and meadow vegetation patterning: Water Resources Research, v. 43, no. 7, 10.1029/2006wr005233, p. W07414.

Luck, Matthew, Maumenee, Niels, Whited, Diane, Lucotch, John, Chilcote, Samantha, Lorang, Mark, Goodman, Daniel, McDonald, Kyle, Kimball, John, and Stanford, Jack, 2010, Remote sensing analysis of physical complexity of North Pacific Rim rivers to assist wild salmon conservation: Earth Surface Processes and Landforms, v. 35, no. 11, p. 1,330-1,343, doi:10.1002/esp.2044.

Madej, M.A., 1982, Sediment transport and channel changes in an aggrading stream in the Puget Lowland, Washington: U.S. Forest Service General Technical Report PNW-141, p. 97-108.

Madej, M.A., 1987, Residence times of channel-stored sediment in Redwood Creek, northwestern California, in Beschta, R.L., Blinn, T., Grant, G.E., Ice, G.G., and Swanson, F.J., eds., Erosion and sedimentation in the Pacific Rim: Wallingford, United Kingdom, p. 429438.

Madej, M.A., Currens, Christopher, Ozaki, Vicki, Yee, Julie, and Anderson, D.G., 2006, Assessing possible thermal rearing restrictions for juvenile coho salmon (Oncorhynchus kisutch) through thermal infrared imaging and in-stream monitoring, Redwood Creek, California: Canadian Journal of Fisheries and Aquatic Sciences, v. 63, no. 6, p. 1,384-1,396, doi:10.1139/f06-043.

Madej, Mary Ann, and Ozaki, Vicki, 1996, Channel response to sediment wave propogation and movement, Redwood Creek, California, USA: Earth Surface Processes and Landforms, v. 21, no. 10, p. 911-927, doi:10.1002/(sici)1096-9837(199610)21:10<911::aid-esp621>3.0.co;2-1.

Magee, Teresa, Ringold, Paul, and Bollman, Michael, 2008, Alien species importance in native vegetation along wadeable streams, John Day River Basin, Oregon, USA: Plant Ecology, v. 195, no. 2, p. 287-307, doi:10.1007/s11258-007-9330-9.

Maloszewski, Piotr, and Zuber, A Andrzej, 1993, Principles and practice of calibration and validation of mathematical models for the interpretation of environmental tracer data: Advanced Water Resources, v. 16, p. 173-190.

McKean, J., Isaak, D., and Wright, W., 2009, Improving stream studies with a small-footprint green Lidar: Eos, Transactions American Geophysical Union, v. 90, no. 39, p. 341-342.

McNeil, W. J., and Ahnell, W.H., 1964, Success of pink salmon spawning relative to size of spawning bed materials: U.S. Fish and Wildlife Service, Special Report Fisheries No. 469, Washington, D.C., 15 pages.

Mecklenburg, D., and Ward, A, 2004, STREAM modules-Spreadsheet tools for river evaluation, assessment, and monitoring, in proceedings of the ASAE Specialty Conference 
Self-Sustaining Solutions For Streams, Watersheds, and Wetlands: St. Joseph, Michigan, American Society of Agricultural and Biological Engineers, p. 312-322.

Micheli, E.R., and Kirchner, J.W., 2002a, Effects of wet meadow riparian vegetation on streambank erosion. 1. Remote sensing measurements of streambank migration and erodibility: Earth Surface Processes and Landforms, v. 27, no. 6, p. 627—639, doi:10.1002/esp.338.

Micheli, E.R., and Kirchner, J.W., 2002b, Effects of wet meadow riparian vegetation on streambank erosion. 2. Measurements of vegetated bank strength and consequences for failure mechanics: Earth Surface Processes and Landforms, v. 27, no. 7, p. 687-697, doi:10.1002/esp.340,.

Montgomery, D.R., and Buffington, J.M, 1998, Channel processes, classification, and response: River ecology and management, v. 112, p. 1,250-1,263.

Montgomery, D.R., Buffington, J.M., Smith, R.D., Schmidt, K.M., and Pess, George, 1995, Pool spacing in forest channels: Water Resources Research, v. 31, no. 4, p. 1,097-1,105, $10.1029 / 94 \mathrm{wr} 03285$.

Montgomery, D.R., Abbe, T.B., Buffington, J.M., Peterson, N.P., Schmidt, K.M., and Stock, J.D., 1996, Distribution of bedrock and alluvial channels in forested mountain drainage basins: Nature, v. 381, no. 6583, p. 587-589.

Mouw, J.E.B., Chaffin, J.L., Whited, D.C., Hauer, F.R., Matson, P.L., and Stanford, J.A., 2013, Recruitment and succesional dynamics diversify the shifting habitat mosaic of an Alaskan floodplain: River Research and Applications, v. 29, no. 6, p. 671-685, doi:10.1002/rra.2569.

National Marine Fisheries Service, 2011, Anadromous salmonid passage facility design:

Portland, Oregon, National Marine Fisheries Services, Northwest Region, 138 p.

O'Connor, J.E., Mangano, J.F., Anderson, S.W., Wallick, J.R., Jones, K.L., and Keith, M.K., 2014, Geologic and physiographic controls on bed-material yield, transport, and channel morphology for alluvial and bedrock rivers, western Oregon: Geological Society of America Bulletin, doi:10.1130/B30831.1.

O'Connor, J.E., Jones, M.A., and Haluska, T.L., 2003, Flood plain and channel dynamics of the Quinault and Queets Rivers, Washington, USA: Geomorphology, v. 51, no. 1-3, p. 31-59, http://dx.doi.org/10.1016/S0169-555X(02)00324-0.

O'Daniel, S.J., 2005, Interactions Between Regional-scale Variation in Geomorphology and Potential for Hyporheic Exchange Along the Umatilla River, Oregon: University of California at Santa Barbara, Master's Thesis, 132 pages.

Olden, J.D., and Poff, N.L., 2003, Redundancy and the choice of hydrologic indices for characterizing streamflow regimes: River Research and Applications, v. 19, no. 2, doi:10.1002/rra.700, p. 101-121.

Opperman, J.J., and Merenlender, A.M., 2000, Deer herbivory as an ecological constraint to restoration of degraded riparian corridors: Restoration Ecology, v. 8, no. 1, p. 41-47, doi:10.1046/j.1526-100x.2000.80006.x.

Oregon Department of Environmental Quality, 1995, Temperature-1992-1994 Water quality standards review: Portland, Oregon, Final Issue Paper, 122 p., http://www.fishlib.org/Bibliographies/waterquality.html.

Oregon Department of Fish and Wildlife, 2006, Division 412-Fish passage criteria: Oregon Department of Fish and Wildlife, Oregon Administrative Rules, 14 p.

Oregon Department of Fish and Wildlife, 2009, Division 412-Fish passage criteria: Oregon Department of Fish and Wildlife, Oregon Administrative Rules, 17 p.

Osman, Y.Z., and Bruen, M., 2002, Modelling stream-aquifer seepage in an alluvial aquifer: an improved loosing-stream package for MODFLOW: Journal ofHydrology, v. 264, p. 69-86. 
Pitlick, J.C. and Thorne, C.R., 1987, Sediment supply, movement, and storage in an unstable gravel-bed river, in Thorne, C.R., Bathurst, J.C., and Hey, R.D., eds., Sediment transport in gravel-bed rivers: London, United Kingdom, p. 121-150.

Poff, N.L., 1997, Landscape filters and species traits: towards mechanistic understanding and prediction in stream ecology: Journal of the North American Benthological Society, v. 16, no. 2, p. 391-409.

Pollock, M.M., Beechie, T.J., Chan, S.S., and Bigley, Richard, 2005, Monitoring restoration of riparian forests, in Roni, P., ed., Monitoring stream and watershed restoration: Bethesda, Maryland, American Fisheries Society, p. 67-96.

Pollock, M.M., Wheaton, J.M., Bouwes, Nick, Volk, Carol, and Jordan, C.E., 2012, Working with beaver to restore salmon habitat in the Bridge Creek intensively monitored watershedDesign rationale and hypotheses: Seattle, Washington, U.S. Deptartment of Commerce, NOAA Technical Memo, NMFS-NWFSC-120, 47 p.,

http://www.nwfsc.noaa.gov/assets/25/8751_10252012_112535_WorkingWithBeaverTM120We bFinal.pdf.

Pollock, M.M., Beechie, T.J., and Jordan, C.E., 2007, Geomorphic changes upstream of beaver dams in Bridge Creek, an incised stream channel in the interior Columbia River Basin, eastern Oregon: Earth Surface Processes and Landforms, v. 32, no. 8, p. 1,174-1,185, doi:10.1002/esp.1553.

Poole, G.C., O'Daniel, S.J., Jones, K.L., Woessner, W.W., Bernhardt, E.S., Helton, A.M., Stanford, J.A., Boer, B.R., and Beechie, T.J., 2008, Hydrologic spiralling-The role of multiple interactive flow paths in stream ecosystems: River Research and Applications, $\mathrm{v}$. 24,no. 7, p. 1,018-1,031, doi:10.1002/rra.1099.

Poole, G.C., and Berman, C.H., 2001, An ecological perspective on in-stream temperatureNatural heat dynamics and mechanisms of human-caused thermal degradation: Environmental Management, v. 27, no. 6, 10.1007/s002670010188, p. 787-802.

Pringle, Catherine, 2003, What is hydrologic connectivity and why is it ecologically important?: Hydrological Processes, v. 17, no. 13, p. 2,685-2,689, doi:10.1002/hyp.5145.

Rantz, S.E., 1982, Measurement of stage and discharge. Vol. 1, Measurement and Computation of Streamflow, Water-supply Paper 2175, U.S. Geological Survey, 284 p.

Rasmussen, P.P., Gray, J.R., Glysson, G.D., and Ziegler, A.C., 2009, Guidelines and procedures for computing time-series suspended-sediment concentrations and loads from in-stream turbidity-sensor and streamflow data: U.S. Geological Survey Techniques and Methods, Book 3, Chap. 4, $52 \mathrm{p}$.

Regier, H.A., Welcomme, R.L., Steedman, R.J., and Henderson, H.F., 1989, Rehabilitation of degraded river ecosystems, in Proceedings of the International Large River Symposium: Canadian Special Publication in Fisheries and Aquatic Sciences, v. 106, 86-97 p.

Reid, L.M., and Dunne, Thomas, 1996, Rapid evaluation of sediment budgets: Reiskirchen, Germany, Catena Verlag GMBH, 164 p.

Roni, P., Leirmann, M., Muhar, S., and Schmutz, S., 2013, Chapter 8: Prioritization of watersheds and restoration projects, in Roni, P. and Beechie, T., eds., Stream and Watershed Restoration: A Guide to Restoring Riverine Processes and Habitats, Wiley-Blackwell, Chichester, UK, p. 189-214.

Rosgen, D.L., 1994, A classification of natural rivers: Catena, v. 22, no. 3, p. 169-199, http://dx.doi.org/10.1016/0341-8162(94)90001-9. 
Schenk, L.N., and Bragg, H.M., 2014, Assessment of suspended-sediment transport, bedload, and dissolved oxygen during a short-term drawdown of Fall Creek Lake, Oregon, winter 2012-13: U.S. Geological Survey Open-File Report 2014-1114, 80 p., http://dx.doi.org/10.3133/ofr20141114.

Skidmore, P., Beechie, T., Pess, G., Castro, J., Cluer, B., Thorne, C., Shea, C., and Chen, R., 2013, Chapter 7: Developing, designing, and implementing restoration projects, in Roni, $\mathrm{P}$. and Beechie, T., eds., Stream and Watershed Restoration: A Guide to Restoring Riverine Processes and Habitats, Wiley-Blackwell, Chichester, UK, p. 189-214

Stanford, J.A., Lorang, M.S., and Hauer, F.R., 2005, The shifting habitat mosaic of river ecosystems: Verhandlungen des Internationalen Verein Limnologie, v. 29, no. 1, p. 123-136.

Steiger, Johannes, Tabacchi, Eric, Dufour, Simon, Corenblit, Dov, and Peiry, J.L., 2005, Hydrogeomorphic processes affecting riparian habitat within alluvial channel-Floodplain river systems-A review for the temperate zone: River Research and Applications, v. 21, no. 7, p. 719-737, doi:10.1002/rra.879.

Stella, J.C., Hayden, M.K., Battles, J.J., Piégay, Hervé, Dufour, Simon, and Fremier, A.K., 2011, The role of abandoned channels as refugia for sustaining pioneer riparian forest ecosystems: Ecosystems, v. 14, no. 5, p. 776-790, doi:10.1111/j.1526-100X.2009.00537.x.

Stringham, T.K., Krueger, W.C., and Thomas, D.R., 2001, Application of non-equilibrium ecology to rangeland riparian zones: Journal of Range Management, v. 54, no. 3, p. 210-217. Stromberg, J.C., Beauchamp, V.B., Dixon, M.D., Lite, S.J., and Paradzick, Charles, 2007, Importance of low-flow and high-flow characteristics to restoration of riparian vegetation along rivers in arid south-western United States: Freshwater Biology, v. 52, no. 4, p. 651-679, doi:10.1111/j.1365-2427.2006.01713.x.

Tabacchi, Eric, Correll, D.L., Hauer, Richard, Pinay, Gilles, Planty-Tabacchi, Anne-Marie, and Wissmar, R.C., 1998, Development, maintenance and role of riparian vegetation in the river landscape: Freshwater Biology, v. 40, no. 3, p. 497-516, 10.1046/j.1365-2427.1998.00381.x. Thurow, R.F., 1994, Underwater methods for study of salmonids in the Intermountain West: Ogden, Utah, Intermountain Research Station, U.S. Department of Agriculture, General Technical Report INT-GTR-307, 28 p.

Tockner, Klemnent, Malard, Florian, and Ward, J.V., 2000, An extension of the flood pulse concept: Hydrological Processes, v. 14, no. 16-17, p. 2,861-2,883, doi:10.1002/10991085(200011/12)14:16/17<2861::aid-hyp124>3.0.co;2-f.

Torgersen, C.E., Price, D.M., Li, H.W., and McIntosh, B.A., 1999, Multiscale thermal refugia and stream habitat associations of Chinook salmon in northeastern Oregon: Ecological Applications, v. 9, no. 1, p. 301-319, doi:10.1890/1051-0761(1999)009[0301:mtrash]2.0.co;2. U.S. Army Corps of Engineers, 2010, HEC RAS Version 4.1: U.S. Army Corps of Engineers.

U.S. Department of Agriculture, 2005, National inventory and assessment procedure for identifying barriers to aquatic organism passage at road-stream crossings: U.S. Department of Agriculture Forest Service National Technology and Development Program, San Dimas, California, $42 \mathrm{p}$.

U.S. Department of Agriculture, 2006, FishXing Program (3rd ed.): U.S. Department of Agriculture.

U.S. Environmental Protection Agency and U.S. Department of Agriculture, 1998, Clean water action plan-Restoring and protecting America's waters: Cincinnati, Ohio, National Center for Environmental Publications and Information, EPA-840-R-98-001,108 p. 
U.S. Geological Survey, 1983, Magnitude and frequency of floods in Eastern Oregon, Water Resources Investigation Report 82-4078, Portland, Oregon, 45 p., http://pubs.er.usgs.gov/publication/wri824078.

U.S. Geological Survey, 2013, MODFLOW (1.11.00 ed.): U.S. Geological Survey software.

Vannote, R.L., Minshall, G.W., Cummins, J.W., Sedell, J.R., and Cushing, C.E., 1980, The river continuum concept: Canadian Journal of Fisheries and Aquatic Sciences, v. 37, no. 1, doi:10.1139/f80-017, p. 130-137.

Ward, J.V., 1989, The four-dimensional nature of lotic ecosystems: Journal of the North American Benthological Society, v. 8, no. 1, p. 2-8, doi:10.2307/1467397.

Ward, J.V., and Stanford, J.A., 1995, The serial discontinuity concept-Extending the model to floodplain rivers: Regulated Rivers—Research \& Management, v. 10, no. 2-4, doi:10.1002/rrr.3450100211, p. 159-168.

Ward, J.V., Tockner, Klement, Arscott, D.B., and Claret, Cecilé, 2002, Riverine landscape diversity: Freshwater Biology, v. 47, no. 4, 10.1046/j.1365-2427.2002.00893.x, p. 517-539.

Washington Department of Fish and Wildlife, 2009, Fish passage and surface water diversion screening assessment and prioritization manual: Washington Department of Fish and Wildlife, Olympia, Washington, 117 pages plus appendices.

Wheaton, J.M., Brasington, James, Darby, S.E., Merz, Joseph, Pasternack, G.B., Sear, David, and Vericat, Damiá, 2010a, Linking geomorphic changes to salmonid habitat at a scale relevant to fish: River Research and Applications, v. 26, no. 4, 10.1002/rra.1305, p. 469-486.

Wheaton, J.M., Brasington, James, Darby, S.E., and Sear, D.A., 2010b, Accounting for uncertainty in DEMs from repeat topographic surveys: improved sediment budgets, Earth Surface Processes and Landforms, v. 35(2), p. 136-156.

White, Seth, Justice, Casey, and McCullough, Dale, 2011, Protocol for snorkel surveys of fish densities. A component of monitoring recovery trends in key spring Chinook habitat variables and validation of population viability indicators: Columbia Inter-Tribal Fish Commission, Portland, Oregon.

Wiens, J.A., 2002, Riverine landscapes: taking landscape ecology into the water: Freshwater Biology, v. 47, no. 4, 10.1046/j.1365-2427.2002.00887.x, p. 501-515.

Wissmar, R.C., 2004, Riparian corridors of eastern Oregon and Washington: functions and sustainability along lowland-arid to mountain gradients: Aquatic Sciences - Research Across Boundaries, v. 66, no. 4, 10.1007/s00027-004-0720-y, p. 373-387.

Woessner, W.W., 2000, Stream and fluvial plain ground water interactions: rescaling hydrogeologic thought: Ground Water, v. 38, no. 3, 10.1111/j.1745-6584.2000.tb00228.x, p. 423-429.

Wright, Justin, Jones, Clive, and Flecker, Alexander, 2002, An ecosystem engineer, the beaver, increases species richness at the landscape scale: Oecologia, v. 132, no. 1, 10.1007/s00442002-0929-1, p. 96-101 
Publishing support provided by the U.S. Geological Survey Science Publishing Network, Tacoma Publishing Service Center

For more information concerning the research in this report, contact the Director, Oregon Water Science Center

U.S. Geological Survey

2130 SW 5th Avenue

Portland, Oregon 97201

http://or.water.usgs.gov 
